PATRÍCIA LUCIANA MOREIRA

\title{
Tornar-se mãe de criança com câncer: construindo a parentalidade.
}

São Paulo

2007 


\section{PATRÍCIA LUCIANA MOREIRA}

\section{Tornar-se mãe de criança com câncer: construindo a parentalidade.}

Dissertação apresentada à Escola de Enfermagem da Universidade de São Paulo para obtenção do título de Mestre em Enfermagem.

Área de Concentração: Enfermagem Pediátrica

Orientadora: $\operatorname{Prof}^{\mathrm{a}} \mathrm{Dr}^{\mathrm{a}}$ Margareth Angelo

São Paulo

2007 
Dedico este trabalho,

\begin{abstract}
À minha família: ao meu pai Luiz, por seu esforço e dedicação sem limites, à minha mãe Izilda, pela serenidade $\mathrm{e}$ amor imensurável, e à minha irmã Priscila pela confiança e coragem que sempre transmitiu em todos momentos que eu precisei.
\end{abstract}

Ao meu noivo Cláudio, pelo suporte, paciência, por acreditar em mim e principalmente, pelo amor e respeito, que tornaram a difícil trajetória mais branda. 
Agradecimentos 
Talvez agradecer seja pouco comparado à dimensão do que essas pessoas me ofereceram. É muito a dizer com palavras e difícil mencionar todos que fizeram do meu caminho um caminho de realização, crescimento e amadurecimento. Serei sempre grata...

À Deus, pela constatação diária da Sua presença em minha vida... Por colocar em meu caminho as pessoas certas, no momento certo.

À Prof $^{\mathrm{a}} \mathrm{Dr}^{\mathrm{a}}$ Margareth Angelo, por acolher minhas inquietações, respeitar meus limites e me ajudar a encontrar o caminho, conduzindo-me com paciência e segurança. Obrigada por dividir comigo um pouco da sua sabedoria, na profissão e na vida e pela confiança que depositou em mim.

À Escola de Enfermagem da Universidade de São Paulo, pelas oportunidades de amadurecimento profissional e desenvolvimento deste trabalho.

À Prof ${ }^{a}$ Dr ${ }^{a}$ Regina Szylit Bousso, pelos conhecimentos compartilhados durante a minha formação e pelas sugestões no Exame de Qualificação.

Prof ${ }^{\mathrm{a}} \mathrm{Dr}^{\mathrm{a}}$ Myriam Aparecida Mandetta Pettengill, pelo respeito e pelas sugestões no Exame de Qualificação.

À Enf. Carla Gonçalves Dias e Enf. Ana Lygia Pires Melaragno, do Instituto de Oncologia Pediátrica, pelo envolvimento com meu trabalho e pelo respeito com que sempre me receberam. Pela atenção e por terem proporcionado a coleta de dados na instituição. À toda equipe de enfermagem do Instituto, pelo suporte durante a nossa convivência.

Ao Conselho de Desenvolvimento Científico e Tecnológico (CNPq), pela concessão da bolsa de estudos. 
Às funcionárias da Secretaria de Pós Graduação da Escola de Enfermagem da Universidade de São Paulo, pela atenção e disponibilidade sempre que solicitei.

Aos funcionários da Biblioteca Wanda Horta da Escola de Enfermagem da Universidade de São Paulo, pessoas fundamentais na construção deste trabalho.

À $\operatorname{Prof}^{\mathrm{a}} \mathrm{Dr}^{\mathrm{a}}$ Lisabelle Mariano Rossato, $\operatorname{Prof}^{\mathrm{a}} \operatorname{Dr}^{\mathrm{a}}$ Elaine Buchhorn Cintra Damião e Enf. Josiane Piccolo, pelas experiências compartilhadas no Programa de Aperfeiçoamento de Ensino (PAE).

À Prof ${ }^{a}{ }^{-a} r^{\underline{a}}$ Giselle Dupas, que apesar da não convivência diária, sempre esteve presente em minha vida. Obrigada, sempre, por despertar em mim a magia de descobrir a criança e a sua família.

À Mariana Lucas Rocha da Cunha, pelo companheirismo, pela alegria, maturidade e por tudo que dividimos: aulas, reflexões, trabalhos e cafés com pão de queijo... Obrigada por tudo que me ensinou e por sua presença.

À Nidia Sandra Guerrero Gamboa, Nara Marilene Oliveira Girardon Perlini e Raquel Candido Ylamas, pelo respeito, confiança e pela amizade que precisamos manter por longos emails... Obrigada por tornarem tudo mais colorido...

À Leandra Maia Diniz, pessoa de tamanha bondade e alegria que Deus colocou no meu caminho no tempo certo... Pelo acolhimento, suporte e compreensão. 
Agradecimento especial 
À todas aquelas que dividiram comigo sua história, permitindo que eu "mergulhasse" na sua experiência de ser mãe de uma criança com câncer. 


\section{SUMÁRIO}

\section{Resumo \\ Abstract}

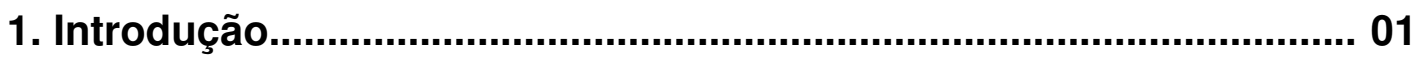

1.1. Despertando para a criança com câncer e sua família.................................... 02

1.2. Buscando evidências sobre a experiência da família da criança com câncer.. 11

1.3. Justificativa, perguntas da pesquisa e objetivos............................................. 32

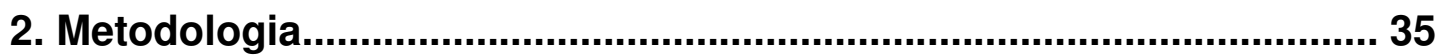

2.1. Referencial Teórico - Interacionismo Simbólico............................................. 36

2.2. Referencial Metodológico - Interacionismo Interpretativo............................. 41

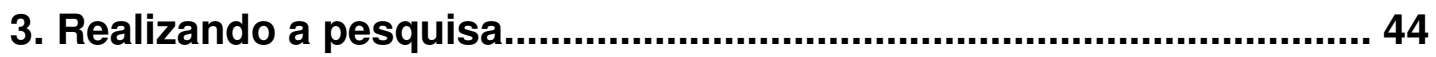

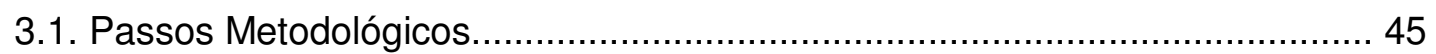

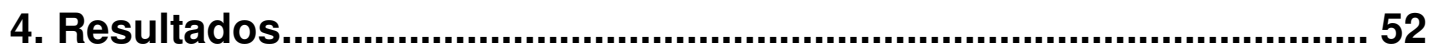

4.1. Compreendendo a experiência de ser mãe de uma criança com câncer.......... 53

4.2. Identificando os momentos reveladores da experiência................................ 121

5. Discussão dos resultados............................................................126

Discutindo evidências da experiência de ser mãe de uma criança com câncer.... 127

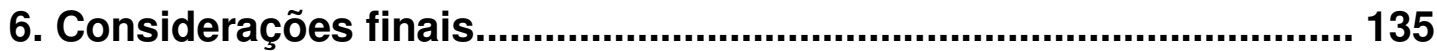

6.1. Tecendo algumas considerações acerca da experiência............................... 136

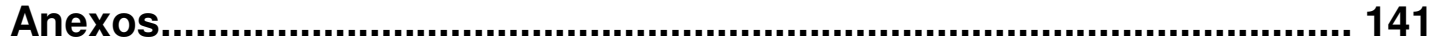

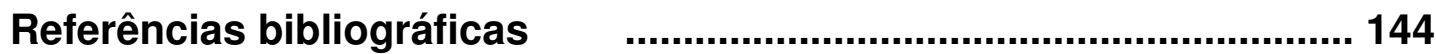




\section{LISTA DE DIAGRAMAS}

Diagrama 1 - Tema: VIVER O TEMPO DA DOENÇA............................................. 55

Diagrama 2 - Subtema: Descobrir-se mãe de uma criança com câncer................. 57

Diagrama 3 - Subtema: Arriscar-se com o tratamento............................................ 67

Diagrama 4 - Tema: VIVER UM TEMPO DE LUTA PELA VIDA DA CRIANÇA..... 76

Diagrama 5 - Subtema: Preparar-se para um tempo de batalha............................ 78

Diagrama 6 - Subtema: Lutar pela vida da criança.............................................. 91

Diagrama 7 - Temas, subtemas e epifanias................................................. 125 
RESUMO

Moreira PL. Tornar-se mãe de criança com câncer: construindo a parentalidade [dissertação]. São Paulo: Escola de Enfermagem da Universidade de São Paulo; 2007.

Este estudo teve como objetivo compreender a experiência de tornar-se mãe de uma criança com câncer. Foi utilizado como referencial teórico o Interacionismo Simbólico e como referencial metodológico o Interacionismo Interpretativo. Participaram do estudo sete mães de crianças que estavam em tratamento de câncer. As narrativas biográficas revelaram que o papel de mãe é construído num processo articulado, que conjuga a interação entre dois temas: VIVER O TEMPO DA DOENÇA, que representa um olhar da mãe direcionado para si, vivendo agora uma situação nova como mãe, continuamente permeada pelas incertezas inerentes à doença e à necessidade de afastar a ameaça de morte criança e VIVER O TEMPO DE LUTA PELA VIDA DA CRIANÇA, que representa a dimensão dos comportamentos da mãe, que se expressam nas interações consigo mesma, com o filho e com todos os elementos envolvidos na experiência, evidenciando a construção do seu papel de mãe. A descrição dos temas proporcionou a compreensão da experiência de tornar-se mãe de uma criança com câncer através das epifanias: Perceber que seu tempo com a criança está ameaçado, Decidir que este é o tempo da criança e Lutar pela criança movida por amor. Foi possível perceber através desses momentos reveladores que existe uma relação entre a parentalidade e a temporalidade, na qual o tempo se manifesta nesta experiência de transição, como uma das dimensões da construção do papel de mãe de uma criança com câncer.

Palavras-chave: Mães, Relações mãe-criança, Oncologia, Enfermagem Pediátrica. 


\section{ABSTRACT}

Moreira PL. Becoming a mother of a child with cancer: building the motherhood [dissertation]. São Paulo: Escola de Enfermagem da Universidade de São Paulo; 2007.

The objective of the present study was to understand the experience of becoming a mother of a child with cancer. The theoretical framework adopted was the Symbolic Interactionism while the methodological one was the Interpretative Interactionism. Seven mothers of children undertaking cancer treatment took part in the study. The biographic narratives expressed that the mother's role is built in an articulated process that implies the interaction between two themes: LIVING THE TIME OF THE ILLNESS, in which the mother concentrates in herself, now facing a new experience as a mother, continuously permeated by the uncertainties inherent in the disease and the necessity of removing the threats of the child's death; and LIVING THE TIME OF STRUGGLING FOR THE CHILD'S LIFE, which represents the dimension of the mother's behaviour, expressed in interactions with herself, her child and all the elements involved in the experience, showing up the development of her role as a mother. The description of the themes allowed the understanding of the experience of becoming a mother of a child with cancer through the following epiphanies: Perceiving that her time with the child is being threatened, Deciding that this is the child's time and Fighting for the child driven by love. It was possible to observe that there is a connection between the parenting and temporality, in which the time is shown in this transition experience as one of the dimensions in the development of a new role as mother of a child with cancer.

Key-words: Mothers, Mother-child relations, Medical Oncology, Pediatric Nursing 


\subsection{Despertando para a criança com câncer e sua família}

Cuidar de crianças com câncer e suas famílias em minha vivência como enfermeira foi a realização de um desejo que me acompanhou durante toda formação acadêmica, mas que não aconteceu repentinamente. Até então, nunca havia me interessado por crianças, e nem imaginava atuar profissionalmente com elas. A experiência do câncer, porém aconteceu muito cedo em minha vida e de minha família, o que despertou em mim uma série de questões acerca daquela doença tão difícil de enfrentar e das pessoas que a vivenciavam.

O interesse em trabalhar com crianças com câncer despertou da participação como monitora em um evento, no curso de Psico-Oncologia Pediátrica quando fui, por dois anos, graduanda em Psicologia. Neste momento, ao me deparar com a complexidade daquela experiência, percebi que não me interessava por crianças porque não conhecia o universo da criança, e muito menos o universo da criança com câncer. Abandonei o curso de Psicologia, mas não o desejo de trabalhar em Oncologia Pediátrica. Depois de muitas reflexões que envolvem a escolha de uma profissão, decidi que seria a Enfermagem a ciência que eu queria me dedicar. $\mathrm{O}$ anseio por conhecer mais sobre a criança que vivencia o tratamento oncológico e a própria doença manteve-se durante toda minha formação acadêmica. Foi quando passei a ter um maior acesso a publicações que abordavam esta experiência, por exemplo, o estudo de Dupas e Angelo (1997), que considero o início do meu olhar para a experiência da criança em vivenciar o câncer, vislumbrando de uma forma mais clara como a enfermagem poderia estar incluída neste contexto.

Mas não foi neste momento em que a Oncologia Pediátrica realizouse em minha trajetória, e sim, o momento de "descobrir" a criança e, posteriormente, sua família. Durante a graduação atuei como aluna de Iniciação Científica na área de Enfermagem Pediátrica, quando fiz meus primeiros movimentos em direção a um olhar à criança enquanto um ser singular, que vivencia e que conceitua a saúde e a doença de acordo com as 
particularidades do seu processo de desenvolvimento (Moreira e Dupas, 2003). Posteriormente, percebi que era o momento de aproximar-me da criança que vivencia uma doença crônica e então, desenvolvi um novo trabalho de Iniciação Científica que buscou compreender a experiência da criança em conviver com o Diabetes Mellitus (Moreira e Dupas, 2006). Acredito que foi a partir deste momento que passei a perceber não somente a criança, mas também sua família. Porém, ainda não estava preparada para pensar na família enquanto uma unidade de cuidado, bem como madura para compreender a dinâmica familiar na situação de doença. Apesar de perceber a família e considerá-la de extrema importância no cuidado em Enfermagem Pediátrica, o meu olhar estava centrado na criança, no impacto da doença em sua vida, nas mudanças acarretadas pelo diagnóstico, no significado que ela atribuía a doença, bem como na forma como ela a enfrentava.

O início da minha trajetória profissional como enfermeira deu-se na unidade pediátrica de um hospital de médio porte. Confesso que, neste momento, minha assistência estava basicamente voltada às necessidades da criança e questões administrativas exigidas pela instituição. Minha relação com a família existia, na maioria das vezes centrada na figura da mãe, mas era bastante estreita e limitada quase sempre à busca de informações sobre as necessidades e características da criança e às orientações acerca dos cuidados a serem prestados por ela ao filho.

Pouco tempo depois, tive a oportunidade de atuar enquanto enfermeira em uma instituição de especialidades pediátricas, dentre elas a oncologia, na qual assumi o setor de quimioterapia. Começava, então, a realização do desejo de cuidar de crianças com câncer. Foi a partir daí que a família passou a ser inserida no meu processo de cuidar.

Eu era a única enfermeira daquela instituição e junto a equipe, cuidávamos das crianças com câncer, de suas necessidades físicas e emocionais, orientando as mães quanto aos cuidados domiciliares durante $o$ tratamento quimioterápico, entrando em contato com enfermeiras de outras instituições que as crianças poderiam precisar, na tentativa de estender o 
nosso cuidado quando a criança estivesse fora do serviço. Tínhamos como princípio, eu e meus companheiros, fazer tudo o que estava ao nosso alcance para promover o alívio do sofrimento e conforto àquelas crianças.

Sentia-me realizada enquanto profissional e pessoa. As crianças se apegavam conosco, solicitavam-nos, aceitavam-nos. As mães eram quem geralmente as acompanhavam nas consultas, sessões de quimioterapia, procedimentos médicos e de enfermagem. Elas verbalizavam a tranquilidade de nos ter cuidando de seus filhos, a confiança em nosso trabalho e a importância do suporte de promovíamos, ouvindo e dividindo angústias, alegrias, expectativas.

Porém, cuidar de uma criança com câncer não era uma tarefa fácil. $A$ todo tempo lidávamos com o sofrimento físico, emocional e espiritual das crianças e suas famílias, e com o nosso sofrimento também. $O$ envolvimento com aquelas vidas era inevitável. Muitas vezes, percebia-me a beira do meu próprio limite. Além disso, vivenciava a necessidade de estudar muito e cada vez mais, conhecer a rotina de outros serviços e como a assistência ocorria nesses locais de forma a prestar o melhor cuidado possível. Não havia como improvisar. Tudo era minucioso, o que causava um enorme desgaste físico e emocional.

Os meus valores, plantados por meus pais e regados pelas minhas vivências, assim como os meus ideais enquanto enfermeira se concretizavam a cada dia, a cada experiência. Aquele cuidado fazia sentido para mim, pois neste processo de cuidar, podia ser eu mesma, sem máscaras, apenas o meu modo de ser e fazer enfermagem, o que eu acreditava ser o meu papel enquanto enfermeira. Sentia-me parte da vida daquelas crianças e famílias, mais especificamente daquelas mães, e colocava-me no lugar delas, tentando compreender o que estavam sentindo. Assim, percebia cada vez mais aquela mulher que cuidava, chorava, sorria, fazia, questionava, refletia, movimentava-se. Isso tudo me fazia refletir... Como era ter um filho com câncer? Como era, para essas mulheres e mães, ver a sua criança adoecer com uma doença cujo nome, muitas vezes, não era nem mencionado? 
Sabemos que, mesmo com todos os avanços no tratamento e crescente sobrevida (atualmente, se diagnosticado precocemente e tratado em centros especializados, a possibilidade de cura chega a 80\%), o câncer infantil ainda é uma doença grave, o que intensifica a ansiedade dos pais da criança doente. Devido à complexidade da doença e tratamento, a vida da criança e sua família passam por diversas transformações, sendo necessário adaptarem-se a uma nova rotina e exigências que passam a fazer parte do cotidiano familiar. Na vivência com o câncer, a família defronta-se com inúmeras dificuldades, dentre elas as situações de sofrimento físico e emocional, bem como manter a interação saudável dentre os familiares. $O$ tratamento é geralmente invasivo, doloroso e agressivo, gerando incertezas e ameaças constantes para a criança e sua família. Preocupações e perdas, angústias e restrições, assim como ameaça de morte passam a fazer parte do seu cotidiano (Costa e Lima, 2002; Françoso e Valle, 1994; Melo e Valle, 1999).

Assim, atentava-me para as mães das crianças que cuidava, não somente colocando-me no seu lugar, mas também buscando proporcionar apoio, atender às suas necessidades, fornecer orientações que elas julgavam necessárias para a sua compreensão da situação e da experiência e promover suporte no enfrentamento da doença. Foi quando que, ao vivenciar a confirmação do diagnóstico de leucemia para a mãe de uma criança de quatro anos, passei a questionar: como a mãe convive com a experiência do diagnóstico de câncer do filho? Quais as mudanças que o diagnóstico acarreta na vida da mãe e da família e como lidam com essas mudanças? Quais os sentimentos e as incertezas no momento em que se percebe mãe de uma criança com câncer?

Percebi, desta forma, que cuidar da criança com câncer significa cuidar também de sua família, e que a compreensão desta experiência me possibilitaria vislumbrar novos caminhos para que a essência do meu cuidado pudesse suprir as reais necessidades dessas crianças e suas famílias enquanto pessoas e sujeitos ativos na experiência de doença. 
Mediante minhas inquietações e retomando um objetivo que nasceu ainda na graduação, me senti preparada e decidida a procurar o programa de Pós-Graduação em Enfermagem, não somente como uma forma de aprendizado, mas também como uma oportunidade de responder aos questionamentos que a experiência de ser enfermeira em oncologia pediátrica despertaram em mim.

Considerando que a experiência do diagnóstico de câncer na criança é um evento que altera toda a dinâmica familiar, a preocupação com a família tem se tornado cada vez mais o foco de atenção e de estudos na área da enfermagem.

Família é um sistema ou unidade na qual existe um compromisso e um vínculo entre os membros que a compõe e cujas funções de cuidado consistem em proteção, alimentação e socialização (Angelo e Bousso, 2001). Porém, mesmo sendo uma unidade de cuidado e, desta forma, essencial no que diz respeito à assistência de enfermagem, percebe-se frequentemente que ela é abordada basicamente como um recurso em benefício do indivíduo, receptora de orientação e fonte de informações, não enquanto um objeto de atenção da enfermagem. As ações de apoio oferecidas à família não atingem a sua experiência e são pouco efetivas. $O$ enfermeiro, por sua vez, deixa-se guiar pelo bom-senso, fundamentado pelo sentimentalismo, sendo também responsável pelas regras que definem como as famílias devem se sentir e agir em determinadas situações (Angelo, 1997).

Estudiosos de diversos países têm se dedicado à construção e à evolução do conhecimento na área da enfermagem da família, considerando-a como um centro de cuidado. Existe também uma busca considerável em compreender o fenômeno da família e da dinâmica familiar em situações diversas, dentre elas a sua experiência mediante a situação de doença de um dos membros. Sendo a família muito mais que a simples adição de cada membro, a enfermagem da família deve se concentrar nas relações entre esses membros, não em elementos isolados. Desta forma, a ocorrência de uma mudança ou de um fato significante com algum dos 
membros da família afeta a todos os demais, ocorrendo um período de adaptação e ajustamento à nova situação. "Quando uma mudança ocorre na família, após a perturbação, ocorre uma alteração para uma nova posição de equilíbrio. A família reorganiza-se ou se reequilibra de modo diferente da organização familiar anterior" (Wright e Leahey, 2002).

Quando o evento doença acontece na vida da família, é necessário rever a sua estrutura e funcionamento para construir um lugar para a doença nas suas vidas. Diante deste evento, novas demandas vão surgindo e novas tarefas vão sendo acrescentadas à rotina da família e da criança que está doente. Assim, é preciso decidir quem vai cuidar do filho, mudar as rotinas para que as novas tenham o seu lugar e rever os papéis de cada membro. Ou seja, a família passa a reorganizar-se, tendo como foco a doença da criança, desempenhando papéis agora ampliados pela necessidade de cuidá-la (Damião e Angelo, 2004).

Mediante o impacto destas novas circunstâncias, da necessidade de ajustamento e enfrentamento, é fundamental que a enfermagem esteja efetivamente presente, ouvindo, compreendendo, promovendo suporte e interagindo com esta família. Estar com a família é tomar parte de uma história imprevisível, na qual a família tem que "enfrentar com as grandes limitações e possibilidades de que dispõe, bem como fatos que não gostaria de passar ou que não esperava ter que viver" (Angelo, 1999).

Numa perspectiva interacionista, família é definida como um "grupo de indivíduos (atores), chegando às situações com outros significantes ou grupos de referência, como símbolos, perspectivas, self, mente e habilidade para assumir papéis. Cada ator tem um passado a resgatar para ajudar a definir a situação e cada um tem uma visão de futuro. Os atores dão significado às situações usando estes instrumentos, às vezes prestando especial atenção àqueles com quem interagem na situação, outras vezes usando algo localizado fora da situação como guia" (Angelo, 1997).

A família é, portanto, uma unidade de cuidado, um grupo social dinâmico na qual os membros interagem e que, mediante uma situação de agravo à saúde, apoiam-se mutuamente e esforçam-se na busca de suprir 
as necessidades da pessoa doente e melhorar sua qualidade de vida. $\mathrm{Na}$ experiência da doença, a família busca manter-se saudável, agindo, reagindo e interagindo internamente e com o contexto social no qual está inserida. Além disso, ela muitas vezes assume papéis nunca antes desempenhados, visando apoiar e suprir as necessidades da pessoa doente, melhorando sua qualidade de vida (Bielemann, 2003).

Assim, os caminhos que percorri através das aulas, leituras e principalmente, pelas orientações da Profa. Dra. Margareth Angelo, me levaram a perceber que muitas das minhas questões já estavam respondidas nas publicações nacional e internacional. Explorar as evidências sustentadas pela literatura e as orientações permitiram que eu despertasse para um novo olhar para a criança com câncer e sua família, um caminho ainda a ser percorrido, uma âncora na qual pude apoiar as minhas reflexões acerca da experiência de ser mãe de uma criança com câncer: a parentalidade.

A parentalidade como categoria de análise é mais abordada em estudos na área da psicologia. A parentalidade é um processo complexo não somente produto do parentesco biológico, mas do processo de tornar-se pai e mãe. Este termo teve origem em 1961, quando foi proposto pelo psicanalista francês e especialista em psicoses puerperais Paul-Claude Racamier o termo maternalidade (em inglês, motherhood), ou seja, o "conjunto de processos psicoafetivos que se desenvolvem e se integram na mulher por ocasião da maternidade". Racamier acrescentou ainda o termo paternalidade e, na junção de ambos, propôs a denominação parentalidade. $\mathrm{O}$ termo parentalidade permaneceu em desuso até que, em meados dos anos 80, o francês Serge Lebovici, psiquiatra infantil e psicalista, propôs uma definição de parentalidade "como o resultado de ser pai ou mãe", e também da "parentalização dos pais", que vai além do processo biológico: "um verdadeiro processo psíquico". Além disso, a parentalidade poderia ser definida como um estudo dos vínculos de parentesco e dos processos psicológicos que se desenvolve a partir destes vínculos. Ela necessita de uma preparação e aprendizagem, um processo que põe em evidência a 
complexidade do fenômeno natural do parentesco; ela abrange uma série de cuidados prestados à criança e a maneira pela qual os pais cuidam dela, buscando assegurar seu bem-estar e desenvolvimento (Silva e Solis-Ponton, 2004)

A parentalidade também pode ser definida como a habilidade de oferecer cuidado e proporcionar um ambiente que promova um ótimo crescimento e desenvolvimento a qualquer ser humano. O termo "família" pode ser usado amplamente como uma referência ao ambiente social no qual a parentalidade é conduzida. "Família" é, por esta razão, um ambiente de relações sociais (Franck e Callery, 2004).

Diversos outros estudos têm se dedicado a estudar a parentalidade e os estilos e práticas parentais nas relações entre pais e filhos, entendendo por estilos parentais o conjunto de comportamentos dos pais que se expressam nas interações entre eles. Nesta interação, os pais respondem às necessidades que a criança tem de atenção, incentivo, diálogo, auxílio, diversão, assim como as respostas de supervisão e monitorização dos comportamentos do filho, exigindo obediência e cumprimento dos deveres. Os estilos parentais também podem ser definidos como as formas como os pais lidam com as questões de poder, hierarquia e apoio emocional na relação com os filhos (Weber et al 2004; Costa et al, 2000).

Amazonas e Braga (2006), ao discutirem sobre as novas formas de parentalidade, discorrem sobre as famílias patriarcas nas quais o pai detinha o poder de vida e morte sobre todos os membros da família. Pouco a pouco, este poder absoluto foi questionado e, com as grandes guerras, a afirmação do trabalho feminino e os movimentos feministas, as transformações sociais, culturais e econômicas, culminaram em pais dividindo com as mães o cuidado e o afeto com os filhos, exercendo funções até então destinada somente às mulheres. Ou seja, um outro modo de exercício da parentalidade.

A mudança de papéis e funções da família, porém, não tem acontecido com a mesma freqüência e intensidade em todas as famílias, sendo, portanto, fundamental conhecer o contexto de cada família, suas 
crenças, valores e atitudes que definem a distribuição das tarefas e papéis da família. Em estudo sobre as tarefas compartilhadas entre pais e mães no exercício da parentalidade, as evidências mostraram uma concordância da importância no desempenho de suas tarefas educativas enquanto pai e mãe, sendo que a tarefa compartilhada com maior freqüência na perspectiva de ambos foi a de oferecer suporte afetivo aos filhos. Outras tarefas compartilhadas por pais e mães de famílias contemporâneas foram relacionadas ao exercício da disciplina, educação para desenvolver hábitos de higiene, compromisso com a escola e sustento econômico. (Wagner et al, 2005).

A maternidade é considerada um fenômeno social, sobre a qual existe uma imagem aderida na mentalidade dos indivíduos de um grupo social. (Kimura, 1997). A mãe é o eixo da estrutura familiar, e é sob o seu controle que estão a criação e educação dos filhos, o cuidado com a casa e com a saúde dos membros da família. O papel de cuidadora é uma expectativa que se tem dela e que ela tem de si mesma e para cumprir este papel a mãe acaba criando estratégias, dentre elas, a adequação do horário de trabalho às necessidades e atividades dos filhos e à rotina doméstica, a desistência do emprego em favor das demandas dos filhos (Martins e Angelo, 1999).

A partir de todas essas considerações, buscamos na literatura nacional e internacional as evidências acerca da experiência da mãe ao vivenciar o câncer do filho e da parentalidade neste contexto. A revisão da literatura está descrita a seguir. 


\subsection{Buscando evidências sobre a experiência da família da criança com câncer}

Apresentaremos a seguir a revisão da literatura acerca de como a experiência de ser mãe de uma criança com câncer vem sendo estudada. Nos últimos 10 anos, diversos estudos dedicaram-se a esta compreensão, envolvendo diversos aspectos que permeiam a experiência. Para a busca bibliográfica, utilizamos bases de dados como Medline, Lilacs e Dedalus. As palavras chaves, tendo como enfoque a experiência da mãe da criança com câncer foram: parenting, mother, motherhood, child, childhood, cancer. Apesar de não utilizarmos a palavra family, muitos artigos abordam também a experiência de outros membros da família, como o pai e os irmãos, mas sempre tendo a mãe como participante da pesquisa. Dentre os artigos encontrados neste processo de busca, selecionamos 72 para análise e revisão da literatura. Mais da metade dos estudos foram realizados por enfermeiras (54\%) e publicada em periódicos norte-americanos (61\%). A maioria refere-se a estudos qualitativos (57\%) e os demais, utilizaram escalas ou questionários para mensuração dos dados (43\%). Quanto aos participantes da pesquisa, todos os estudos remeteram-se às mães e/ou mães e pais para obtenção dos dados e 17 estudos incluíram neste processo crianças e/ou adolescentes com câncer. As evidências dos estudos analisados foram categorizadas em 4 temas: (a) o impacto do diagnóstico sobre a família e os sentimentos que permeiam esta experiência; (b) o ajustamento psicossocial dos pais na vivência do câncer do filho; (c) as estratégias de enfrentamento da família e suas necessidades na experiência do câncer infantil; (d) a parentalidade na situação do câncer infantil. 
(a) O impacto do diagnóstico sobre a família e os sentimentos que permeiam esta experiência.

Esta categoria engloba os estudos que demonstram o impacto do diagnóstico de câncer da criança para a mãe e para a família, bem como os efeitos, sentimentos e aspectos comportamentais gerados a partir deste momento.

As principais evidências a respeito deste tema revelam que o diagnóstico de câncer na criança é um acontecimento traumático, que provoca grande desorganização e desequilíbrio na rotina e dinâmica familiar. No período inicial, após ter sido informado o diagnóstico, os pais da criança geralmente ficam sob o impacto da notícia, podendo este estado de choque durar algumas semanas. Além disso, é comum os pais apresentarem mecanismos de defesa variados, como a negação da doença e sua gravidade, sentimentos de culpa, sintomas de depressão e ansiedade (Bessa, 1997). Insegurança, medo, desespero e perda também são alguns sentimentos que invadem a criança com câncer e sua família (Melo e Valle, 1999). Outras reações psicológicas que resultam da revelação do diagnóstico incluem descrença, tristeza, negação, confusão, raiva e distanciamento. $\mathrm{O}$ medo foi bastante relacionado à complexidade da nova situação, ao futuro da vida da criança, a desorganização familiar e a ruptura de aspectos significantes da vida (Patistea et al, 2000). Comparado a outros momentos do tratamento e consequências da doença, o medo acerca da morte provavelmente está presente. O nível de estresse no diagnóstico de câncer na criança só é menor comparado ao estresse em caso da morte do filho (Martinson et al, 1997).

Receber o diagnóstico de câncer do filho, além de ser um momento de crise que causa impacto em toda a família, é também, muitas vezes, experienciar a dificuldade em acessar o sistema de saúde e os problemas de comunicação com os profissionais sendo, freqüentemente, uma fonte de frustração. Os pais têm o desejo de controlar algum aspecto no cuidado à saúde da criança (Ward-Smith et al 2005). A demora do diagnóstico muitas 
vezes causa nos pais a sensação de raiva ou culpa, bem como o sentimento de que suas crianças não foram ouvidas ou aceitas pelos profissionais de saúde (Sloper, 1996). Os pais têm a necessidade de que reconheçam as suas reações mediante o diagnóstico, como a negação, o estresse da dor, o medo da hospitalização e a ameaça da morte da criança, bem como a necessidade de informação acerca da doença e tratamento (Yiu e Twinn, 2001). A fim de compreender e descrever as percepções dos pais na circunstância do diagnóstico de câncer do filho e do processo de consentimento informado, um estudo demonstrou que o conteúdo e a maneira como cada informação sobre a doença da criança foi comunicada é considerado importante para os pais durante essa fase. Muitos pais utilizam uma variedade de recursos para ajudá-los a enfrentar o câncer da criança, assimilando informações e tomando decisões acerca do tratamento (Levi et al, 2000).

Ao ser confirmado o diagnóstico de câncer, a criança passa, aos olhos dos pais, de uma criança saudável a uma criança doente (DixonWoods et al, 2001). Além disso, o impacto do diagnóstico de câncer na criança influi nas práticas exercidas pelos pais de retaguarda, expectativas, disciplinas, expressão das emoções, preocupação e proteção se comparadas a pais de crianças consideradas saudáveis (Hillman, 1997).

Após o diagnóstico, um estudo com crianças com retinoblastoma demonstrou que as reações da maioria das famílias foi de raiva e tristeza, e que oscilavam entre os dois extremos, ou seja, entre o "isto não é perigoso" e "meu filho irá morrer". Em geral, as mães reagiram intensamente à crise, enquanto os pais mostraram seus medos de forma mais racional e prática. Depois de 8 a 12 meses do diagnóstico e sem tumores novos emergindo, os pais viam seu filho como a mesma criança que antes do diagnóstico, colocando a doença em segundo plano e sentindo que suas vidas gradualmente retornava ao normal (Ulla, 2000). Ao "tornarem-se" famílias de crianças com câncer, os pais passam por um processo que consiste em tentar encontrar um estado normal dentro da experiência, aceitar e reconhecer que suas vidas mudaram com o diagnóstico, compreender que 
precisam se ajustar à nova experiência, aceitar que não podem mudar os eventos estressantes e os descontentamentos neste caminho (Tarr e Pickler, 1999).

Ao investigarem o impacto do diagnóstico e tratamento do câncer no bem-estar psicológico em adolescentes com câncer e seus pais, comparando a um grupo controle, autores perceberam que entre os adolescentes dos dois grupos, não existiram diferenças significativas nos níveis de depressão, e os adolescentes com câncer não são mais ansiosos que os adolescentes do grupo controle. As mães têm um nível de ansiedade significativamente mais alto comparado aos pais, sendo o membro da família que apresenta mais significativa ansiedade (Allen et al, 1997). Além disso, mães de crianças com câncer relataram menor qualidade de vida e maior preocupação comparadas a mães de crianças saudáveis. A avaliação da mãe quanto a sua própria qualidade de vida está intimamente relacionada com a qualidade de vida da criança, que, durante meses após o diagnóstico, é significativamente comprometida (Eiser et al, 2005).

$\mathrm{Na}$ percepção de crianças com câncer e seus pais sobre os problemas e os efeitos da doença na sua situação de vida, foram identificadas categorias relativas ao tratamento médico e efeitos colaterais, isolamento, intimidade familiar e suporte, sentimentos e reações, qualidade do cuidado. (Enskär et al, 1997a). A separação e a ruptura da vida da família causadas pela hospitalização da criança têm efeito negativo e muitos deles sentem que seus familiares ficaram mais fechados desde o diagnóstico (Sloper, 1996).

Os eventos mais citados como estressantes e causadores de angústia na dimensão física por crianças com câncer, seus pais e enfermeiros foram: a dor resultante dos procedimentos de diagnóstico e tratamento, náusea e fadiga. Na dimensão emocional, estão o confinamento, o sentimento de alienação e a preocupação antes dos procedimentos médicos (Hedström et al, 2003). Na visão dos profissionais de saúde, a criança é mais preocupada com os sintomas físicos, a dependência dos pais, perdas, contato reduzido com os amigos, as regras do hospital, as 
limitações de movimento. Os membros da família são mais preocupados com os eventos possíveis e ansiedade sobre o futuro e recidiva, efeitos na economia, ansiedade sobre a morte e perdas e futuro, novos valores dados à vida, incerteza, impotência, regras de visitas nos hospitais (Enskär et al, 1996). As maiores dificuldades em lidar com a doença da criança na fase inicial foram os problemas psicológicos, financeiros e falta de controle (Patistea et al, 2000). 
(b) O ajustamento psicossocial dos pais na vivência do câncer do filho

A categoria referente ao ajustamento psicossocial dos pais enfoca evidências de estudos direcionados à adaptação mediante a situação, geralmente influenciada e relacionada a diversos fatores, que muitas vezes ultrapassam as dimensões psicológicas e sociais.

Após o impacto do diagnóstico, os pais passam por um período de ajustamento, sofrendo a influência de diversos fatores como o estresse, enfrentamento, suporte social e tempo de diagnóstico. O suporte familiar é associado a um melhor ajustamento nas famílias de crianças com câncer (Han, 2003). Mediante a evidência do diagnóstico de câncer na criança ser a representação de mudanças na vida da família, estudos apontam altos níveis de estresse em mães (por sua vez um dos fatores que influenciam no ajustamento psicossocial), bem como sintomas depressivos e estados de ansiedade (Han, 2003; Frank et al, 2001). Mães e pais apresentam altos níveis de angústia em relação aos estressores potenciais, como eventos da doença, problemas financeiros e com o emprego. A coesão familiar é um importante recurso para pais e mães (Sloper, 2000).

Além do estresse, ansiedade e depressão, a vivência do câncer traz para a mãe um efeito negativo no seu senso de domínio das situações, sendo um mediador entre a incerteza e a ansiedade, na qual a incerteza e as limitações da situação estão fortemente relacionadas. Quando a mãe mantém o senso de domínio constante, a correlação entre ansiedade e incerteza é reduzida (Mu et al, 2001).

Acerca da relação entre ajustamento e enfrentamento dos pais e crianças/adolescentes com câncer, um estudo demonstrou que apesar das crianças sobreviventes ao câncer demonstrarem estar mais adaptadas que os pais, as vivências da doença têm significados negativos para ambos (Delella e Araújo, 2002). Para os adolescentes, a adaptação tem como recurso a proximidade com os pais e alguns amigos, sendo capazes de adaptarem-se neste contexto com base na força familiar e suporte social. Dentre os pais, percebeu-se o uso de estratégias de enfrentamento e 
diminuição da angústia no que diz respeito ao ajustamento psicossocial, e que seu nível de angústia está relacionado com o nível de angústia dos adolescentes (Trask et al, 2003).

No processo de adaptação individual e familiar, mães relatam a importância da relação com os médicos e esposos, o que parece atenuar os sintomas depressivos e o senso de responsabilidade mediante a doença do filho (Shapiro et al, 1998). Ainda que mães e pais compartilhem a experiência e a responsabilidade de cuidado com o filho doente, mães e pais experienciam a angústia diferentemente. Mães de crianças com câncer apresentaram maiores níveis de angústia, depressão e ansiedade comparados aos pais, bem como as mães com diagnóstico recente do filho, comparadas as mães de crianças fora de tratamento (Yeh, 2002).

Quanto a idéia de bem-estar, não existe diferença de gênero entre os pais da criança com câncer, porém seus níveis diferem significativamente: é alta a porcentagem de mães com alto indicativo de problemas de estresse comparado aos pais (Svavarsdottir, 2005b). As mães que apresentam altos níveis de angústia apresentaram maiores níveis de estresse emocional e as crianças de mães com altos níveis de estresse apresentaram-se mais angustiadas (Steele et al, 2004).

Os pais relataram altos níveis de angústia psicossocial no momento do diagnóstico, seguido por um declínio no decorrer do tempo (HoekstraWeebers et al, 2001; Steele et al, 2003). Após o diagnóstico, os pais parecem experienciar uma crise composta por traumas e ansiedade, que reduz continuamente. Pais de crianças em tratamento revelam níveis mais altos de angústia do que pais de crianças fora de terapia (Boman et al, 2003). O ajustamento durante o tratamento representa um significante desafio para os pais no enfrentamento da doença. Após cerca de três meses do diagnóstico, há um aumento da estabilidade que pode refletir a adaptação dos pais para as demandas e incertezas da fase inicial do tratamento (Steele et $\mathrm{al}, 2003)$. O suporte social também parece diminuir com o tempo, sugerindo existir uma variação na mobilização dependendo do estresse da situação. Isso parece interferir no ajustamento já que mães que se ajustaram 
melhor psicologicamente receberam mais suporte e são menos insatisfeitas do que mães que continuaram clinicamente angustiadas (Hoekstra-Weebers et al, 2001).

Em comparação aos níveis de ansiedade entre um grupo composto por crianças e suas mães em tratamento oncológico e um grupo de crianças e suas mães fora de tratamento, o grupo em terapia apresentou significativamente maior estado de ansiedade comparado ao grupo fora de terapia. As crianças que completaram o tratamento de câncer e suas mães apresentaram melhor ajustamento que aquelas que estão recebendo tratamento. Além disso, existe uma relação entre as respostas de ajustamento das crianças e das mães. Se a mãe é ansiosa, a criança tende a tornar-se ansiosa também (Moore e Mosher, 1997). A ansiedade parental no contexto da distração de pré-escolares durante o procedimento pode proceder a um importante papel nas respostas das crianças na intervenção de distração. As crianças que não responderam favoravelmente à distração tiveram pais que estavam significativamente mais ansiosos que os pais de outras crianças participantes (Dahlquist e Pendley, 2005). Ao avaliar se o estresse parental difere entre pais de crianças com inabilidades físicas e pais de crianças com câncer, autores revelaram que pais de crianças com câncer relatam significativamente mais altos níveis de estresse em comparação os pais de crianças com inabilidades físicas. O estresse parental foi estatisticamente abaixo no grupo de crianças com inabilidades, bem como na mensuração da interação disfuncional entre pais e crianças. Isso sugere que os pais no grupo de crianças com câncer percebem maior estresse na interação pai-criança. Os pais de crianças com câncer têm significativamente níveis mais altos de estresse que os outros pais. (Hung et al 2004).

Ao explorar o impacto psicossocial do câncer nas crianças e suas famílias e a intensidade da depressão experienciada por essas crianças, os pais percebem uma significativa diminuição do humor dos seus filhos e também relatam ajustamentos nas suas atitudes e comportamentos com relação à criança desde o diagnóstico. Os pais tornam-se mais protetores, 
mais tolerantes e menos exigentes com relação às crianças. Ocorrem positivas mudanças na relação da criança com seus pais e irmãos depois do diagnóstico de câncer. A crise pode transformar-se em uma oportunidade para a família toda de renovar seus relacionamentos e ter uma nova perspectiva de vida. Entretanto, muitos fatores podem afetar o bem-estar psicossocial depois do diagnóstico de câncer, como a idade, gênero, suporte social e familiar (Chao et al, 2003). Mães e pais de crianças com câncer tem uma avaliação mais insatisfatória de humor do que aqueles do grupo controle. Mães de crianças com câncer têm significativamente avaliações mais insatisfatórias de vida social do que mães do grupo controle. Para os pais, as habilidades de enfrentamento são mais insatisfatórias se comparadas aos pais do grupo controle. Para mães de crianças com câncer com doença ativa, suporte social insatisfatório poderia até certo grau ser a conseqüência da insatisfatória vida social. (Dockerty et al, 2000).

Imediatamente após o diagnóstico, as crianças com câncer e seus pais apresentaram mais problemas psicológicos comparadas às crianças e pais da comunidade. Entretanto, durante os anos subseqüentes, não houve diferença entre o número de problemas experienciados pelas crianças e pais de ambos os grupos (Sawyer et al, 2000). Após um longo tempo do diagnóstico da criança, mães relatam sentimentos de solidão e os pais, sentimentos de solidão, desamparo e incerteza. Ter uma criança com recidiva elucida ansiedade, sentimentos de desamparo e incerteza. Mães e pais de crianças com câncer geralmente tem expectativas positivas sobre 0 curso da doença, e aparentemente não antecipam desapontamento, mas um senso de otimismo, que gera o sentimento de controle (Grootenhuis e Last, 1997). 
(c) As estratégias de enfrentamento da família e suas necessidades na experiência do câncer infantil

Como antes mencionado, o diagnóstico de câncer provoca um momento de desestruturação, não somente para a criança, mas para todas as pessoas que com ela convivem. O enfrentamento permeia a experiência do câncer, muitas vezes influenciado pelas situações em que a família se encontra, bem como sua própria percepção sobre a doença da criança. Mediante esta situação, toda família se reorganiza de forma a enfrentar a doença e buscar equilíbrio, como indicam as evidências dos estudos. Esta categoria abarca o maior número de estudos desta revisão, e se referem às estratégias e necessidades da família para o enfrentamento na experiência de câncer.

Quando a criança tem o diagnóstico de câncer, a família experiencia este fato como se toda sua vida estivesse passando por um processo de quebra, tornando-se ciente da mortalidade e vulnerabilidade e desejando escapar da situação que muitas vezes, sai do próprio controle. É como se a doença governasse a vida da família como um todo (Björk et al, 2005). Nas narrativas de famílias sobre a trajetória do câncer, a experiência de doença também é relatada como a maior experiência de suas vidas e como um pesadelo. Depois que o câncer é diagnosticado, eles não são capazes de viver suas vidas como sabiam e apreciavam, ocorrendo uma mudança na unidade familiar e em cada um de seus membros. O maior medo das famílias é a perda da criança e a separação familiar (Woodgate, 2006). A família então, começa a lutar, não somente no que se refere à sobrevivência da criança, mas também esforçam-se na luta para manter a família unida (Björk et al, 2005; Woodgate, 2006). Percebe que a vida tem que continuar e esforçam-se para sentir esperança e um foco positivo. Tenta retomar o controle e reduzir o caos em que se encontram, bem como se juntar a outras pessoas como uma forma de diminuir o sentimento de solidão. A equipe, parentes, amigos e, para alguns, a confiança em Deus, proporciona para a família a esperança de que a criança irá sobreviver (Björk et al, 2005). As 
famílias dão ênfase para a importância de manter o espírito vivo, de moverem-se adiante e mudar para algo novo, continuando suas vidas para alcançar um objetivo diferente na sua jornada. Mesmo assim, o câncer permanece como parte deles, modelando suas vidas e sua biografia (Woodgate, 2006). Os pais sentem-se de repente como aprendizes, ambos em termos de doença e também de "ser pais" da sua criança. Os membros da família adquirem novos conhecimentos e procuram manter alguma espécie de normalidade na vida da família (Björk et al, 2005).

A experiência do câncer infantil ocasiona diversos efeitos na vida dos pais que precisam enfrentar: a obrigação da proximidade, as dificuldades financeiras, a perda do emprego, o sacrifício, a dor e a angústia emocional. Esta obrigação de proximidade freqüentemente envolve dificuldades consideráveis em cumpri-la, como reações à dor, desconforto e angústia. A sensação de estar vivenciando uma luta é mais evidente no momento do diagnóstico do câncer, no qual os pais ao invés de dramatizar suas crianças como uma inocente vítima de forças malignas, enfocam a idéia de interrupção e questionam: "Porque minha criança, porque nós?" (DixonWoods et al, 2003). Mesmo assim, tendo ou não respostas, os pais enfrentam os desafios e as novas exigências, necessidades e desafios impostos após o diagnóstico. Os pais da criança com câncer são e sentemse responsáveis por ela e buscam informações, conhecimento e compreensão sobre a doença, participando do cuidado e tratamento de seus filhos (Clarke e Fletcher, 2003).

Como conseqüência dos desafios da situação do câncer nas vidas das famílias, os pais sentem-se impotentes ao verem suas crianças sofrerem, dominados pela doença. Comportam-se diferentemente como membro da família tendo seus papéis modificados pelo enfrentamento da doença, experienciando fortes sentimentos e reações. Os pais tentam enfrentar a doença lidando com as reações dos outros e encontram neles suporte e avaliam a qualidade do cuidado prestado à criança. A incerteza é para os pais a pior coisa que eles tem de enfrentar, mas dão ênfase na importância do pensamento positivo (Enskar et al, 1997b). A família 
experiencia, do começo ao fim na sua trajetória em vivenciar o câncer, estágios variáveis de incerteza, que dependem da situação em eles estão experienciando. Algumas situações citadas foram: informação do diagnóstico, procedimentos invasivos repetitivos, morte, mudanças nas relações sociais, hospitalização. A incerteza foi associada a sensação de conviver com o desconhecido, inclusive de não saber o que esperar. (Woodgate e Degner, 2002).

Ainda sobre o enfrentamento, um estudo traz as experiências e necessidades de famílias rurais de crianças com câncer, no qual a família relata a dificuldade em ir para longe de casa e as grandes mudanças que afetam toda a família. Por outro lado, a família revela ser a experiência de vivenciar o câncer uma caminhada que precisa ser realizada, geralmente motivada pela esperança. Os pais verbalizam o desejo de se "libertarem" da doença para que suas vidas pudessem voltar ao "normal". O suporte familiar aparece como fundamental e uma estratégia de enfrentamento é tentar manter algo de "normal" na vida familiar (Scott-Findlay e Chalmers, 2001). Esse senso de normalidade é descrito em um estudo que teve como objetivo observar diferenças étnicas entre famílias chinesas e norte-americanas que experienciam o câncer de suas crianças. Ao final do primeiro ano depois do diagnóstico, apesar da criança doente permanecer como prioridade, a vida da família foi descrita como mais branda, com mais alegria e socialização, ainda que as famílias permaneçam em alerta para complicações e recidiva (Leavitt et al,1999).

Como já mencionamos, a maneira como os pais enfrentam a situação de câncer nos filhos demonstra que os pais percebem a doença da criança como uma situação séria e ameaçadora e que buscam estratégias de enfrentamento para manter a força da família e uma perspectiva otimista. Os pais enfatizam também a fé em Deus e o diálogo com os profissionais de saúde. Os pais partem do princípio de que a criança precisa deles e assume as responsabilidades e o cuidado da criança doente, querendo utilizar seu tempo com elas (Patistea, 2005). Ao cuidarem de suas crianças, os pais vivenciam um impacto na sua saúde física e emocional, dando importância 
às condições que preservem seu tempo e energia, como o suporte de amigos e parentes (James et al, 2002). Os pais encontraram em seus esposos e esposas uma fonte de suporte, assim como a família extensa, ou seja, médicos e enfermeiros. Pais e mães utilizam diferentes estratégias de enfrentamento depois da confirmação do diagnóstico: os pais utilizam recursos na busca de soluções e informação como efetivos meios para o enfrentamento; as mães focalizam o cuidado na criança e buscam responder às suas necessidades. A maior parte das mães também declararam que foram ajudadas conversando com aqueles que entendiam o que eles estavam passando (Wills, 1999).

Ao investigar as diferenças de estratégias de enfrentamento entre pais de crianças com câncer e pais de crianças saudáveis, autores encontraram altos níveis de ansiedade e depressão no primeiro grupo, porém as diferenças quanto às estratégias de enfrentamento entre ambos não foram significativas. Na relação entre estratégias de enfrentamento e níveis de ansiedade e depressão, foi mais freqüente o uso de atividades focalizando o problema e menos freqüente as reações paliativas (tentar relaxar ou fazer outras atividades), comportamentos de fuga (retirar-se da situação problemática), reações passivas (isolamento) e expressão de emoções negativas (como tristeza e raiva) (Norberg et al, 2005).

No enfrentamento da doença, os pais fazem referência a importantes aspectos do cuidado e da assistência, como o cuidado acessível, informação, suporte emocional, financeiro e social (von Essen et al, 2001). Para crianças com câncer, os aspectos do cuidado e assistência que são importantes foram competência social, divertimento e satisfação de necessidades básicas. Para enfermeiros, pais e crianças com câncer, a competência social foi um dos três mais freqüentes mencionados aspectos do cuidado. Pais e enfermeiros, mas não as crianças, mencionaram a importância da continuidade, comunicação honesta, e tempo para a criança sentir-se cuidada. A importância da competência clínica foi mencionada exclusivamente por pais (Enskär e von Essen, 2000). Em outro estudo, os aspectos mais difíceis do cuidado na percepção dos pais foram: a fragilidade 
emocional da criança, reação emocional exagerada quando se sente prejudicado, necessidade de ser acalmado, solidão, necessidade de amigos, temperamento furioso, rebeldia, teimosia e medo da recidiva. $\mathrm{O}$ desejo e necessidade de ser positivo, balanceado pela necessidade de estar preparado para o pior, foi parte do novo desafio de enfrentamento relatado neste período do tratamento. Os pais expressam preocupações sobre as implicações futuras da experiência de doença (Leavitt et al,1999).

Ao vivenciarem a trajetória da doença, os pais estabelecem significados para a circunstância, considerando a doença como seu destino e algo que eles devem aceitar (Wong e Chan, 2005). Os pais aceitam a realidade e convivem com suas conseqüências em um processo dinâmico, variado e contínuo no enfrentamento. Esse processo consiste em identificar a condição de suas crianças; esforçam-se para preservar a vida da criança no cuidado, mantendo otimismo; ajustam-se aos efeitos colaterais, complicações e variações emocionais da criança; acessam a causa da doença e seu impacto procurando significado da vida e doença por crenças espirituais; adaptam-se diariamente às mudanças da situação e ajustam seus estilos de vida para ajudar suas crianças sobreviverem. Os pais envolvem-se intensivamente na monitorização das respostas de suas crianças sendo esta uma estratégica de enfrentamento (Yeh, 2003). Além disso, os pais confrontam a realidade pela busca ativa de suporte e informações, que os ajudam a compreender a doença e na tomada de decisões acerca do tratamento de suas crianças. Eles também procuram suporte emocional através dos profissionais de saúde e amigos, e de pais que passaram por experiências similares. Os pais foram otimistas e tiveram esperanças no futuro, sendo capazes de identificar novas perspectivas para sua experiência e ver nela aspectos positivos, como a família ficar mais unida. (Wong e Chan, 2005).

As demandas do cuidado prestado por pais de crianças com câncer de mais intenso significado foram: encontrar a necessidade emocional da criança doente, atender aos equipamentos médicos, confortar a criança nos procedimentos dolorosos, planejar atividades para a criança doente durante 
o tratamento, viajar durante o tratamento e disciplinar a criança doente. As tarefas associadas a encontrar as necessidades emocionais da família, informações e necessidades de comunicação e manutenção a função familiar frente a doença e tratamento são importantes dimensões das demandas do cuidado parental. (Wells et al, 2002).

As famílias primeiramente passam por um período em que algo indica que a sua criança tem uma doença mais séria, caracterizado pelo isolamento, espera e desconhecimento. O choque do diagnóstico é seguido de um período em que as famílias constroem uma nova rotina, cujas estratégias são definidas pelos membros da família, individualmente ou em comum acordo, para integrar a experiência do câncer da criança no dia-a-dia familiar. As estratégias utilizadas pela família, cujo objetivo comum é tentar normalizar suas vidas, são: administrar o fluxo de informações acerca da doença da criança; reorganizar papéis dentro da família de acordo com as demandas da doença; avaliar e alterar prioridades, questionando, mantendo ou alterando valores e prioridades; mudar a orientação para o futuro, na qual os planos são dificultados pela incerteza, mas que encontram um meio para pensar no futuro através da esperança e da confiança na cura da criança; designar significado à doença, influenciado pela explicação de mundo de cada família; administrar o tratamento, já que a família é geralmente quem cuida da criança. (Clarke-Steffen, 1997)

Dentre os recursos necessários para o enfrentamento da doença entre pais de crianças que vivem próximas, e pais e crianças que vivem distantes dos centros de tratamento, os pais relatam o suporte de informação (da doença, tratamento e cuidado), o suporte emocional (suporte espiritual, confiança e habilidade de questionamento) e suporte instrumental (ajuda para moradia, transporte, refeição e alguém para cuidar dos filhos que ficam em casa enquanto eles acompanham a criança em tratamento) (Mercer e Ritchie, 1997). Durante a fase ativa do tratamento do câncer, pais relatam que eles esforçam-se para balancear as múltiplas necessidades da família: trabalho, escola, outros filhos, achar o cuidado para a criança, estar no hospital. Os pais são capazes de identificar muitas coisas positivas e 
características das pessoas que ajudaram suas famílias a lidar com as muitas forças associadas à experiência do câncer: os recursos da própria criança (personalidade e comportamento), os recursos da família e da comunidade e as estratégias de enfrentamento (específicos comportamentos dos membros da família). (Patterson et al, 2004).

Pais de crianças com câncer relataram significativamente maior reflexão, maior defesa e maior busca de informação comparadas aos pais de um grupo controle. O nível de qualidade de vida das crianças com câncer e seus pais, independente de gênero, é significativamente mais baixo no grupo das crianças com câncer. Quanto ao enfrentamento parental, as mães usam mais freqüentemente estratégias de busca de suporte social, busca de informação e enfrentamento religioso, comparando-se aos pais. Elas têm mais sucesso em manter a integração familiar e o otimismo, em manter a estabilidade pessoal e em entender a situação clínica de sua criança. As mães são mais envolvidas no suporte a suas crianças e geralmente quem as acompanha no hospital (Goldbeck, 2001). Comparadas aos pais, as mães relataram mais freqüentemente o uso de procura de suporte em situações de estresse. Não foram encontradas significativas diferenças entre os gêneros acerca do suporte percebido ou ansiedade. A relação entre o suporte percebido e ansiedade foi moderado, e a relação entre procura por suporte e suporte percebido foi reduzida. A significância do suporte social foi forte para mães do que para pais (Norberg et al, 2006).

A não compreensão dos amigos e familiares e demora em receber informações da criança não ajudam no cuidado à criança, sendo as informações pelos profissionais da doença e tratamento a mais importante ajuda. Os pais reconhecem que eles não são adequadamente atentos a suas próprias necessidades, escolhendo enfocar as necessidades da criança doente e outros membros da família (James et al, 2002). Pais e mães relataram que precisam saber mais sobre as condições de suas crianças e que as informações dadas aos pais são centradas primariamente aos aspectos biomédicos das condições da criança. Os pais, porém, relatam que necessitam de informações adicionais a respeito das ramificações 
psicossociais da situação (Patistea e Babatsikou, 2003). Os pais têm preferências sistemáticas sobre o controle de decisão no tratamento e a maioria deles prefere o papel colaborativo neste processo. As informações que consideram de maior prioridade foram acerca do tratamento e exames, a probabilidade de cura da doença, e o cuidado à criança. Como média prioridade, o impacto emocional do câncer na criança doente, os possíveis efeitos colaterais do tratamento, o impacto físico do câncer na criança doente, a doença. As menores prioridades, enfrentamento com procedimentos dolorosos, o impacto do câncer infantil na família. Os pais que preferem papéis ativos, colaborativos ou passivos na tomada de decisão no tratamento têm diferentes perfis de necessidades de informação, que não são diferentes nas diversas fases na trajetória do tratamento (Pyke-Grimm et al, 1999).

Para mães e pais de crianças com câncer a maior parte do tempo consumido e as maiores dificuldades são atribuídas ao suporte emocional para a criança e outros membros da família. Mães encontram dificuldades no manejo de problemas comportamentais, coordenar, organizar e administrar serviços para os membros da família, proporcionar cuidado para a criança, estruturar e planejar atividades para a família. Os pais, por outro lado, percebem-se conduzindo o trabalho fora de casa e organizando o cuidado para a criança ao mesmo tempo, proporcionando também suporte emocional para sua esposa (Svavarsdottir, 2005a). 
(d) A parentalidade na situação do câncer infantil

Mães e pais diferem em suas experiências frente ao diagnóstico e tratamento do câncer, provavelmente como reflexo da tradição de seus papéis caracterizados pelo gênero e baseados na divisão do trabalho. Alguns estudos foram encontrados forneceram evidências à temática da parentalidade, a maior parte deles tendo como foco a experiência da mãe.

Mães e pais têm diferentes percepções acerca da parentalidade na experiência do câncer infantil. Quando uma criança tem o diagnóstico de câncer, é frequente a mãe aprender rapidamente a lidar com os aspectos médicos da doença, bem como a lidar com as necessidades dos membros da família. Assim, a mãe é vista como a principal pessoa no cuidado da criança doente. Para a mãe, é importante passar um tempo em casa com a família, o que envolve suporte do esposo e ajuda aos outros irmãos da criança doente a se adaptarem às mudanças, inclusive a perda da atenção dos pais (Brown e Barbarin, 1996).

Mães, mesmo que não doentes elas mesmas, experienciam e vivenciam muitas consequências da doença, que se iniciam com a notícia de que algo não vai bem com a criança e se intensificam com o diagnóstico. $O$ diagnóstico de câncer na infância traz consigo uma significativa crise na família, sendo um momento de transição, de definir e redefinir os papéis de mãe. Junto à proximidade com a criança, assumem um sentimento de responsabilidade, expectativa e proteção. A doença traz consigo uma percepção da criança enquanto um ser dependente e vulnerável. Nesta experiência, ela apresenta uma constante preocupação com dietas, disciplinas e vigilância, bem como as consequências da doença e tratamento de seu filho, vivenciando inclusive a possibilidade da morte. Quando fala da experiência, utiliza o termo "nós", como se fosse um desejo de trocar de lugar com o filho. Ela também quer manter a identidade da criança, acreditando ser uma "guardiã" de sua biografia, e não querendo que ela seja vista como herói. Assim, cuidar da criança com câncer acarreta diversas implicações na vida e na qualidade de vida da mãe, dentre elas o conflito de 
manter-se próxima ao filho em tratamento, mas também desenvolver o papel de mãe de outros filhos (Young et al, 2002b)

Na experiência de mães sul-americanas em ir para os Estados Unidos para tratamento da criança, a possibilidade da morte é o que motiva a sua decisão de sair do país. O impacto e choque do diagnóstico, o rompimento de suas vidas e o filho "tornar-se uma criança com câncer" causam preocupações constantes. Os desafios culturais com a língua, divergências de estilos de maternidade, modo de vida, alimentação são enfrentados com persistência e esperança, fé e conforto. As mães sentem que fazem qualquer coisa dentro de seu poder para restaurar a saúde da criança; parece que as mães transcendem o difícil caminho de sua situação de vida (Crom, 1995).

A mãe, além de responsável primária no cuidado da criança, é também responsável por atuar em situações particulares ocasionadas pelo tratamento, como a dor, o sofrimento, vulnerabilidade e mudanças de comportamento. Para ela, o cuidado à criança é um trabalho em período integral, que consome suas vidas e não permite utilizar o tempo com outras atividades. Relatam a necessidade de serem guardiãs da criança, protegendo-a de infecções e outros perigos potenciais ou até fatais em decorrência do tratamento. Este cuidado é planejado e quando ele não ocorre como esperado, desencadeia um sentimento de frustração e estresse (Clarke et al, 2005).

O processo de tornarem-se pais de uma criança com câncer começa quando os pais recebem a notícia de que algo está errado. Tornarem-se pais de uma criança com câncer é uma notável transição biográfica. Embora não eles mesmos doentes, os pais experienciam muitas das consequências da doença, incluindo a ruptura biográfica, compromisso na função dos papéis e a diminuição da qualidade de vida (Young et al, 2002a).

$\mathrm{Na}$ trajetória da doença, os sintomas do câncer são vividos pela criança e pela família em diversos períodos de transição, e contribuíram na reflexão dos papéis, responsabilidades e como eles existiam como família. Os sintomas conduzem a momentos interacionais na vida das crianças e 
suas famílias, existindo uma relação interdependente entre sintomas, câncer e o modo de ser no mundo. Os períodos de transição identificados vão desde a manifestação dos primeiros sintomas, que não indicam o câncer nem interferem nos papéis e nas atividades da família, passando pela percepção de que eles significam algo mais sério, pelo momento do diagnóstico, visto como um golpe e no qual o foco da vida da família foi essencialmente determinado pelos sintomas. O caminho das mães foi estritamente associado à criança, tornando-se mais vigilantes em cuidar da criança e dar mais atenção aos sintomas, protegendo-a de estresses adicionais. Cuidar de sua criança torna-se prioridade para as mães. (Woodgate e Degner, 2004). Pais de crianças com câncer descrevem que assumiram um papel importante na comunicação com o filho doente durante período do diagnóstico, manejando o que, quando e como suas crianças foram informadas sobre sua doença. (Young et al, 2003).

Assim que os pais e mães recebem o diagnóstico de câncer de seus filhos, eles iniciam um processo contínuo para aprender a viver com a doença da criança como parte integral de suas vidas. A resposta inicial ao diagnóstico é a percepção de que seu mundo havia acabado, já que o conhecimento que tinham acerca da doença os aproximava da idéia de morte iminente. Mediante a possibilidade de a criança sobreviver, os pais e mães decidem fazer tudo que estivesse ao seu alcance para manter a criança viva e começam a reorganizar suas vidas ao redor da doença da criança, vivendo um mundo de esperança mesclado a um temor constante de que a doença volte a atacar. Além disso, é diferente a forma como pais e mães assumem as diferentes fases do tratamento devido ao fato de que os pais não estão tão envolvidos quanto as mães, que assumem o cuidado do filho doente, da casa, do esposo e de si mesma. (Catillo e Catherine, 2003)

Ao vivenciarem as demandas do tratamento, pais de crianças com câncer relataram a importância de manterem alguma semelhança com a situação anterior e a família unida. Alguns mencionam a necessidade de continuar a trabalhar em meio-período como uma forma de fazer algo que antes eles faziam. O pai é quem assume a responsabilidade por trabalhar, 
enquanto a mãe assume a responsabilidade de estar com a criança no hospital. Os pais experienciam mudanças nos seus papéis usuais, o que muitas vezes é um papel conflituoso: a mãe renuncia o seu papel de cuidar dos outros filhos e manter a vida diária da casa e da família. Os pais que não haviam até então se envolvido com o cuidado do filho agora têm que aprender como lidar com ela. Além disso, eles vivenciam o conflituoso papel entre estar no hospital com o filho e manter a responsabilidade de conduzir todas as suas obrigações no local de trabalho (McGrath, 2001).

Descrições dos pais de crianças em tratamento por câncer acerca de como eles participaram de cuidado revelam a proteção como tema emergente, definida como pais falando e agindo em favor à sua criança, como um intercessor e defensor, para assegurar que as necessidades de suas crianças serão satisfeitas. Os esforços de proteção são mais aparentes em dois importantes períodos: a fase do diagnóstico, procurando uma explicação médica para os sintomas e persistindo para ter um diagnóstico exato, e na fase do tratamento, informando-se sobre o estado médico da sua criança e necessidades, decidindo sobre o tratamento médico de suas crianças, limitando e restringindo alguns procedimentos com suas crianças e assegurando suporte e promovendo o relacionamento com a equipe médica (Holm et al, 2003). 


\subsection{Justificativa, perguntas da pesquisa e objetivos}

Com base na revisão da literatura, foi possível identificar alguns componentes significativos para a compreensão da experiência da família da criança com câncer, onde a ênfase é dada, sobretudo, às dificuldades psicológicas de pais, mães e crianças com câncer. Percebe-se, no entanto, uma deficiência referente à compreensão mais profunda do papel da mãe, em especial quanto ao entendimento do processo social incluindo os comportamentos da mãe relacionados a uma reflexão da construção da parentalidade mediante essa experiência.

Sendo a mãe, em muitos estudos, identificada como a principal fonte de suporte e quem geralmente assume o cuidado da criança na situação de doença (Dupas et al, 1998; Bessa, 1997; Brown e Barbarin, 1996; Young et al, 2002b; Eiser et al, 2005; Shapiro et al, 1998; Svavarsdottir, 2005; Mercer e Ritchie, 1997; Yeh, 2002; Yeh, 2003; Clarke et al, 2005; MacGrath, 2001, Goldbeck, 2001, Leavitt et al, 1999, Castillo e Catherine, 2003), interessounos compreender:

- Quais seriam, no âmbito do câncer infantil, as dimensões do ser mãe na experiência do diagnóstico de câncer do filho?

- Quais os significados que a mãe atribui à doença do filho?

- Como a mãe vivencia o seu papel de mãe frente a esta situação?

De acordo com a revisão de literatura realizada, percebemos que a experiência da mãe de uma criança com câncer pode, muitas vezes, ser limitada aos sentimentos, aos fatores de ajustamento psicossocial ou estratégias de enfrentamento. É necessário, no entanto, ampliar a compreensão da experiência da mãe. É necessário considerar também como o evento câncer do filho ocorre na vivência da mãe de uma forma integrada, de modo a englobar todos os aspectos da sua experiência.

A perspectiva do cuidado da criança com câncer pela mãe requer uma mudança de paradigma no caminho do pensar sobre esta experiência. Mais especificamente, antes de focalizar no sofrimento psíquico das mães nesta situação, é pensar na força que possuem essas mães, em como elas 
assumem a responsabilidade de ser mãe frente à doença da criança (Clarke et al, 2005).

Estas considerações aproximam a categoria parentalidade do contexto de assistência de enfermagem à família na situação do câncer, justificada pela relevância da compreensão das dimensões que envolvem a experiência de ser mãe de uma criança que vivencia o diagnóstico de câncer. Ser mãe é fazer o papel de mãe, cuidando do filho e proporcionando apoio através de comportamentos que visam suprir as necessidades da criança. De acordo com a literatura, ser mãe é um papel multidimensional, ou seja, abarca dimensões na relação familiar como proximidade, suporte, monitorização, comunicação, conflito e aceitação (Snider et al, 2004). Sendo a experiência de vivenciar o câncer do filho um tempo que traz consigo novas demandas e rotinas, a mãe tem que monitorizar a criança de acordo com estas novas necessidades; a mãe, dentro de uma situação conflituosa, deixa de ser mãe de uma criança considerada "sadia", para ser mãe de uma criança que vivencia uma doença.

As abordagens tradicionais investigam os aspectos psicossociais da doença na infância representando a parentalidade em termos de como os pais se ajustam adequadamente à doença de sua criança. Exploram os elos entre o ajustamento parental e características individuais, como os traços de personalidade, estilos de enfrentamento, percepção da doença ou coesão familiar (Young et al, 2002b).

Compreender a experiência da mulher ao ser mãe da criança com câncer, os significados atribuídos por ela à doença do filho, ao tratamento e ao impacto no cotidiano familiar, bem como ao prosseguir sua caminhada sendo mãe, são fundamentais para o cuidado. Acreditamos que a mãe não necessita, no momento do diagnóstico, somente de orientações acerca da patologia, tratamento e rotinas, mas de suporte para continuar desenvolvendo seu papel de mãe nesta nova situação. Compreender a experiência presente na construção deste papel fornecerá elementos para direcionar mais precisamente as ações de apoio à mãe. Cuidar da criança com câncer significa cuidar também de sua família, e a compreensão desta 
experiência possibilita vislumbrarmos novos caminhos para que a essência do cuidar possa promover o suporte necessário e suprir reais necessidades da mãe enquanto pessoa e sujeito ativo neste processo.

Considerando que a experiência da mulher que vive a experiência de ser mãe de uma criança com câncer demanda melhor compreensão e que a construção deste papel nesta situação necessita de cuidadoso apoio para garantir a plena vivência da experiência pela família na complexa trajetória da doença, estudos necessitam ser realizados para trazer à luz novos aspectos que necessitam ser considerados pelo profissional no cuidado de famílias e de crianças com câncer.

Assim, este estudo tem como objetivo:

- Compreender a experiência de ser mãe de uma criança com câncer. 
2. Metodologia 


\subsection{Referencial Teórico: Interacionismo Simbólico}

Baseado na preocupação em compreender, numa dimensão mais profunda a natureza das interações e a dinâmica social que envolve 0 indivíduo, o Interacionismo Simbólico configurou-se como a perspectiva teórica deste trabalho.

As idéias centrais do Interacionismo Simbólico baseiam-se no processo de interação, no qual os indivíduos são ativos e aprendem a dar significado às coisas, valorizando, sobretudo, o significado que o ser humano atribui às suas experiências (Dupas et al, 1997; Charon, 1989). Estes interagem agindo, percebendo, interpretando, agindo novamente. Assim, sendo o indivíduo ator e reator no processo, é imprevisível e ativo no mundo (Charon, 1989).

As três premissas básicas do Interacionismo Simbólico, segundo Blumer (1969) são:

1. O significado das coisas (objetos físicos, outros seres humanos, idéias, situações da vida cotidiana) resulta ou emerge da interação social que os seres humanos estabelecem uns com os outros. Esta premissa possibilita entender, na presente pesquisa, que a experiência em vivenciar o câncer do filho se associa às interações que a mãe estabelece naquele momento de sua vida com a criança, com a família, com os profissionais e todas as pessoas com quem interage no processo, com a própria doença e com ela mesma.

2. Os significados são manipulados e modificados pelo ser humano por meio de um processo interpretativo que ele utiliza ao lidar com o que encontra. Não se considera a interpretação uma simples aplicação dos significados estabelecidos, e sim um processo formativo no qual os significados são usados e revisados como instrumentos que guiam a ação. Com base nessa premissa, fica evidente que os significados de conviver com o câncer surgem e se modificam nas interações que a mãe da criança estabelece nas situações vivenciadas (consigo mesma, com as outras pessoas, com a doença, situações e objetos). 
3. Os seres humanos agem em relação aos objetos físicos, outros seres humanos e situações da vida cotidiana com base nos significados que elas têm para eles. Tais significados influenciam a formação do comportamento da pessoa, e conhecê-los pode nos levar a compreender a ação humana. Compreendemos, assim, que a ação da mãe em deparar-se com a doença do filho está baseada no significado que ela atribui às coisas com as quais interage.

Alguns conceitos, de acordo com Charon (1989) são fundamentais para a compreensão da perspectiva do Interacionismo Simbólico:

Símbolos: São objetos sociais utilizados para representar e comunicar algo. São definidos na interação e são significativos, já que nós entendemos a sua representação, e significantes porque utilizamos os símbolos pelo significado que acreditamos que tem sentido para o outro. Assim, o símbolo não somente representa e comunica, mas também envolve uma compreensão.

Self: É um objeto social, portanto, emerge da interação social. É o objeto dos nossos atos, em constante mudança para 0 ator, porque é continuamente definido e redefinido na interação social. É o meio interno que guia os nossos atos. O self permite que o indivíduo volte para si mesmo, para a sua situação e imaginar-se nela. Assim, somos capazes de julgar nós mesmos e estabelecer uma identidade. $O$ self é um objeto social que $O$ ator controla.

Mente: Não é um objeto social como o símbolo e o self. É atividade. É toda ação que o indivíduo faz através e em direção a si. É todo pensamento e toda manipulação ativa de símbolos na conversação consigo mesmo e com o seu self. Sendo atividade, a mente é um processo não mecânico e apesar de não ser objeto, pode transformar os objetos. A mente é uma atividade que muda a nossa relação com o ambiente, dentro de uma manipulação ativa. Ela nos faz mais conscientes do mundo a nossa volta, pois faz 
indicações com relação ao nosso self, tem habilidade de controlar ações e de resolver problemas.

Assumir o papel do outro: É o mesmo que assumir a perspectiva do outro, ou seja, ver o mundo a partir do ponto de vista dele. Envolve o uso dos símbolos já que usamos a estrutura simbólica do outro e envolve também o self, importante objeto na interação e porque precisamos transcender nosso próprio ponto de vista para fazer parte do outro e assumir sua perspectiva. Envolve a ação da mente, pois assumir o papel do outro é um ato contínuo a medida que encontramos outras pessoas. Assim, é um processo que acompanha toda interação humana, toda comunicação simbólica; é imaginar o mundo a partir da perspectiva do outro, sem deixar de lado nossa própria perspectiva; é a qualidade que mais me aproxima do outro e enriquece a comunicação humana. Não é um objeto, mas uma habilidade socialmente desenvolvida através das interações sociais.

Ação humana: É um objeto social e interpretada simbolicamente. Cada ação tem uma meta e envolve uma tomada de decisão feita pelo ator, ou seja, planejamos e usamos os objetos sociais de acordo com os nossos planos, definindo a situação. Este é o principal elemento para iniciar a ação e envolve uma interação com o self e com o outro. A ação não pode ser compreendida isoladamente, mas sempre em um contexto.

Interação social: É uma ação social mútua, simbólica, que envolve o assumir o papel do outro. Ou seja, é o que as pessoas fazem e é influenciado pelas ações que acontecem com o passar do tempo e nas definições a partir do que os outros fazem. Assim, a interação social envolve atores em ação social mútua, comunicando-se simbolicamente, assumindo o papel do outro e interpretando uns aos outros. Ela cria a sociedade, ou seja, a sociedade depende dos indivíduos continuamente interagindo uns com os outros e consigo mesmo. 
Além das premissas básicas de Blumer (1969) e dos conceitos fundamentais para a compreensão de uma perspectiva interacionista simbólica, Charon (1989) nos remete às cinco idéias centrais do Interacionismo Simbólico. Essas idéias devem estar claras na escolha do referencial teórico em uma pesquisa interacionista, já que são elas que irão fundamentar a formação do conceito. São elas:

O papel da interação social: O interacionismo simbólico tem seu foco na natureza da interação social. Ou seja, a interação é a sua unidade de estudo. O ser humano tem uma imagem ativa, em constante interação, formando a sociedade. Assim, a sociedade é constituída por indivíduos interagindo, em um processo dinâmico. As pessoas mudam constantemente nesta interação social.

O papel do pensamento: A ação humana é causada não somente pela interação entre indivíduos, mas também pela interação com ele mesmo, ou seja, pensar sobre determinada situação específica, que está presenciando.

O papel da definição: O ser humano não percebe ou sente seu ambiente diretamente; ele define sua situação como uma ação revelada. A definição é o resultado da interação social e do pensamento. O que nós fazemos não resulta simplesmente da realidade como ela é, mas de como nós definimos o que ela é.

O papel do presente: $O$ presente não se refere a um dia, mas a uma situação presente, o agora. Nossas ações resultam do que está ocorrendo em nossa presente situação. O nosso passado vem à nós no presente, mas as ações dependem de como nós pensamos agora.

O papel do ser humano ativo: O ser humano é descrito no Interacionismo Simbólico com ser ativo e livre; é ele quem interage, define, pensa, aplica seu passado no presente e toma decisões baseado na situações imediatas. 
O Interacionismo Simbólico, desta forma, é uma perspectiva que busca compreender o comportamento humano, influenciado pelos símbolos, e não pelo instinto. Esses símbolos mudam de acordo com as experiências e interações. O comportamento de um indivíduo é produto da sua história de vida, continuamente modificada pelas interações e experiências vividas.

Retomamos, então, sob esta perspectiva, a concepção de família enquanto um "grupo de indivíduos (atores), chegando às situações com outros significantes ou grupos de referência, como símbolos, perspectivas, self, mente e habilidade para assumir papéis. Cada ator tem um passado a resgatar para ajudar a definir a situação e cada um tem uma visão de futuro. Os atores dão significado às situações usando estes instrumentos, às vezes prestando especial atenção àqueles com quem interagem na situação, outras vezes usando algo localizado fora da situação como guia" (Angelo, 1997)

Considerando assim a mãe da criança com câncer, interagindo com outras pessoas e eventos e consigo mesma, a perspectiva interacionista, através do processo interpretativo, permite conhecer e compreender essa realidade se definindo, bem como compreender como a circunstância, ser mãe de uma criança com câncer compõe a sua história. O Interacionismo Simbólico torna possível compreender como a mãe, na situação de câncer do filho, interage com o ambiente, com os outros indivíduos e com seu próprio self, construindo dessa forma o papel de ser mãe de uma criança com câncer. Esta construção é um processo dinâmico, que envolve definir situações de acordo com as perspectivas desenvolvidas e alteradas nas interações sociais (Charon, 1989). 


\subsection{Referencial Metodológico: Interacionismo Interpretativo}

Na busca de compreender a experiência de ser mãe de uma criança com câncer, escolhemos o Interacionismo Interpretativo como referencial metodológico. De acordo com Denzin (1989) este método tem como objetivo obter descrições densas e detalhadas das vivências biograficamente importantes que alteraram a forma de agir das pessoas inseridas em um determinado contexto desencadeando uma significação/ressignificação que altera o ser no mundo. $O$ foco de estudo é a experiência desta pessoa que altera e modela os significados atribuídos por ela para si mesma, bem como para os seus projetos de vida. Estas experiências de vida significativamente importantes recebem o nome de epifanias, e têm influência direta na forma como o indivíduo irá interagir com e em seu contexto. Segundo o mesmo autor, as epifanias também podem ser compreendidas como momentos interacionistas que são marcantes na vida da pessoa e que tem grande poder de criar transformações a partir de suas experiências. Ela ocorre em todas as situações interacionais problemáticas nas quais o sujeito se confronta e experiencia a crise. As epifanias, segundo Denzin (1989):

- "Alteram o direcionamento da vida;

- Exercem efeitos nos níveis mais profundos do ser;

- São relembradas de forma que as experiências possam ser relatadas;

- Ocorrem em situações problemáticas que necessitam ser reconsideradas pelo indivíduo;

- Constituem-se em fenômenos interacionais;

- Alteram-se no decorrer do tempo, visto que os significados são atribuídos na interação".

O estudo interpretativo, tendo como foco a epifania, tenta descobrir a complexa inter-relação entre o universal e o particular, entre a desordem privada e as questões públicas na vida da pessoa. Assim, todos os estudos interpretativos são biográficos e históricos; são sempre providos de momentos históricos e sócio-culturais que envolvem a experiência de vida das pessoas. O pesquisador, ao ouvir estas experiências detalhadamente, é 
capaz de esclarecer os momentos de crise que ocorreram na vida daquela pessoa. Assim, existe uma "interação" entre a pessoa que conta a estória e o pesquisador, de quem é exigido a habilidade de falar e ouvir o outro, incluindo ele mesmo. $O$ interacionista interpretativo tenta ver o mundo e seus problemas como eles são vistos pelas pessoas que vivem no interior deste mundo.

O Interacionismo Interpretativo tenta fazer do mundo da experiência vivida algo acessível ao leitor, trazendo-o para a situação, não somente descrevendo-a, mas trazendo também os pensamentos e sentimentos, tornando aquele momento vivo. Podemos dizer que o Interacionismo Interpretativo:

1. Utiliza estudos de caso e métodos biográficos;

2. Encontra as crises e epifanias da vida dos sujeitos;

3. Conecta as experiências, os problemas pessoais para as questões públicas e instituições;

4. Ocupa-se de sofisticado rigor;

5. Apresenta o fenômeno para ser avaliado na linguagem, sentimentos, emoções e ações daqueles que estão sendo estudados;

6. Segue os cinco passos da interpretação: desconstrução, apreensão, agrupamento, construção e contextualização;

7. Situa claramente o pesquisador no fenômeno que está sendo avaliado.

A interpretação é um processo que segue em busca do significado de um evento ou experiência. Compõe uma tríade, ou seja, uma pessoa, um objeto, evento ou processo, e a ação tomada com relação a este objeto, evento ou processo. Desta forma, o significado é interacional e interpretativo. Para alcançar este objetivo, faz-se necessário a obtenção de descrições densas, considerada por Denzin (1989) a "pedra-angular" no estudo interpretativo. É a descrição densa que permite desvendar o significado que dá forma a experiência das pessoas e os subsídios para o processo interpretativo.

A descrição densa ultrapassa os limites do fato por si só e da aparência superficial. Ela apresenta detalhes, contexto, emoção e as 
relações sociais que unem pessoas umas às outras; as vozes, sentimentos, ações e significados dos indivíduos interagindo são ouvidas. Uma descrição densa é biográfica, histórica, situacional, relacional e interacional. A descrição densa é interpretativa: ela apreende as interpretações das pessoas que conduzem aos eventos; ela relata as interpretações que são feitas pelos que estão interagindo; ela proporciona as razões para as interpretações do pesquisador dos eventos e significados. 
3. Realizando a pesquisa 


\subsection{Passos Metodológicos}

\section{Participantes do estudo e aspectos éticos}

Para garantir os direitos das participantes do estudo, foram observados todos os aspectos presentes na Resolução CNS 196/96. Antes de iniciarmos o processo de coleta de dados, o projeto foi submetido à apreciação e obteve aprovação do Comitê de Ética em Pesquisa da Escola de Enfermagem da Universidade de São Paulo (Anexo 1). Foi solicitada a autorização da instituição e o projeto de pesquisa foi aprovado pelo Comitê de Ética do IOP - Instituto de Oncologia Pediátrica, local de coleta de dados.

Foram selecionadas mães de crianças com diagnóstico de câncer cujos filhos estavam em atendimento oncológico. Seis mães foram contactadas no IOP e as entrevistas foram realizadas na instituição, no ambulatório de quimioterapia. As participantes foram selecionadas após observação-participante durante quimioterapia ambulatorial. As mães foram abordadas individualmente e convidadas a participar da pesquisa, compartilhando comigo a sua história. Neste momento, foi explicado para as mães o objetivo do trabalho e como a entrevista seria realizada. Apesar de ser oferecida para a mãe a possibilidade de realizarmos a entrevista em uma sala privativa, todas elas preferiram realizá-la no próprio setor, onde seus filhos estavam recebendo quimioterapia. Foi incluída no grupo de participantes uma sétima mãe que se interessou em compartilhar sua experiência. Apesar de não pertencer ao serviço, a mãe apresentava todos os critérios e condições para ser inclusa. A entrevista foi realizada no próprio domicílio da mãe.

Não foram delimitados idade ou nível sócio-econômico da mãe, bem como idade, tipo de câncer ou tempo de tratamento da criança. Não foram incluídas no estudo mães de crianças em TMO, de crianças fora de possibilidade de cura ou em estado crítico ou instável.

Mediante interesse em compartilhar sua experiência, foram fornecidas às mães informações oralmente e por escrito sobre os procedimentos utilizados no desenvolvimento da pesquisa. O Termo de Consentimento 
Livre e Esclarecido (Anexo 2) foi lido e explicado junto a cada mãe e após a leitura e explicação, sanadas possíveis dúvidas. Considerando que o consentimento para participação na pesquisa é um processo, foi ressaltada que sua participação era voluntária, bem como a possibilidade da interrupção de sua participação em qualquer etapa do estudo, sem qualquer prejuízo, e a destruição ou disponibilidade das fitas gravadas em caso de desistência.

Foi solicitada às mães autorização para a gravação da entrevista. Foram garantidos também o anonimato das participantes, o respeito e a confidencialidade das informações fornecidas aos pesquisadores, enfatizando sua utilização restrita aos estudos propostos. As entrevistas foram realizadas após o consentimento livre e esclarecido da mãe em participar do estudo. Cada mãe assinou o Termo de Consentimento em duas cópias, uma que permaneceu em posse do pesquisador e outra recebida pela mãe.

\section{Coleta de dados}

Alguns dados foram coletados com todas as mães visando a caracterização do grupo de entrevistadas. Como estratégia para aproximação e com a finalidade de construir a história da formação e evolução da família e de compreender a dinâmica familiar, realizei a construção do genograma antes das entrevistas. Assim, foi possível a coleta de informações como idade da mãe, escolaridade, cidade de origem, ocupação, número de filhos, experiências anteriores de doenças e/ou hospitalização do(s) filho(s), e informações sobre a criança, como idade, diagnóstico, tempo e tipo de tratamento.

Antes de cada entrevista, eu apresentava para as mães a proposta de um local para sua realização. Porém, apesar de ter disponível uma sala privativa na qual poderíamos estar durante a entrevista, todas as mães preferiram permanecer junto ao filho em quimioterapia.

As informações coletadas que demonstram as características das mães participantes da pesquisa e de suas crianças estão descritas a seguir: 


\section{Mãe 1}

36 anos, do lar, ensino fundamental incompleto, mora na cidade de São Paulo. É casada e tem 2 filhos: um menino de 11 anos e uma menina de 3 anos. O diagnóstico de Rabdomiossarcoma da menina de 3 anos aconteceu em março de 2005. A criança foi submetida, em 10 meses de tratamento, a cirurgia para retirada do tumor e quimioterapia. É a mãe quem acompanha a filha no processo de tratamento.

\section{Mãe 2}

41 anos, cabeleireira, ensino fundamental completo, proveniente do estado de Sergipe. É casada, tem dois filhos: um menino de 12 anos e um menino de 11. O filho de 12 anos está em tratamento por Leucemia Linfoblástica Aguda recidivada. O diagnóstico aconteceu em março de 2002. Em maio do mesmo ano, a família mudou-se para SP para dar continuidade ao tratamento do filho que se iniciou em Aracaju. O primeiro tratamento com quimioterapia durou 2 anos e 1 mês. Após 1 ano e 6 meses fora de tratamento, aconteceu a recidiva, pela qual está em tratamento quimioterápico há 2 meses. A mãe é o membro da família que acompanha o filho no processo de tratamento.

\section{Mãe 3}

32 anos, do lar, ensino fundamental completo, proveniente do interior do estado de São Paulo. É casada e tem um filho de 5 anos. A criança teve o diagnóstico de Leucemia Linfoblástica Aguda aos 3 anos. A mãe, vendedora de loja de roupas antes do diagnóstico de leucemia do filho, interrompeu a atividade em decorrência das demandas do tratamento da criança. Desde então, há 2 anos e 1 mês, a criança está em tratamento quimioterápico. A mãe é quem acompanha o filho no processo de tratamento. 


\section{$\underline{\text { Mãe } 4}$}

36 anos, trabalha em uma loja de materiais de construção que pertence à família, ensino médio incompleto, proveniente da cidade de São Paulo. Viúva desde 2003. Tem uma filha de 12 anos. A criança teve diagnóstico de Astrocitoma de baixo grau em 2003, pouco antes do falecimento do pai. Em dois anos de tratamento, a criança foi submetida à cirurgia, quimioterapia e radioterapia. Quem acompanha a criança no processo de tratamento é a mãe.

\section{Mãe 5}

38 anos, do lar, ensino médio completo, proveniente de Belém/PA. Casada, tem duas filhas: uma menina de 9 e uma menina de 4 anos. A filha de 9 anos teve diagnóstico de Linfoma de Não-Hodgkin. Até o diagnóstico da filha, trabalhava como gerente de uma loja de fotografia, interrompendo suas atividades para vir morar em São Paulo para realização do tratamento, em setembro de 2005, dias após o diagnóstico. O esposo e a filha mais nova permanecem morando em Belém. A criança foi submetida a cirurgia e quimioterapia. Assim, quem a acompanha a criança no processo de tratamento é a mãe.

\section{Mãe 6}

24 anos, artesã, desenvolvendo suas atividades no lar, ensino médio completo, mora na cidade de São Paulo. É casada e tem dois filhos: um menino de 8 anos e uma menina de 2 anos. $O$ diagnóstico de Rabdomiossarcoma da filha aconteceu quando a mesma tinha 10 meses de idade. Desde então, a criança foi submetida à cirurgia, quimioterapia e radioterapia. Atualmente, após 1 ano e 2 meses do diagnóstico, está no último ciclo de QT para reestadiamento. É a mãe quem acompanha a filha no processo de tratamento. 


\section{Mãe 7}

35 anos, do lar, ensino médio completo, é da cidade do Rio de Janeiro/RJ. É casada e tem uma filha de 10 anos. A criança está em tratamento por recidiva de Osteossarcoma. O diagnóstico aconteceu em fevereiro de 2003 e o tratamento quimioterápico iniciou-se no Rio de Janeiro. Em junho do mesmo ano, mãe e filha mudaram-se para São Paulo para prosseguir o tratamento na cidade. A mãe abandonou a atividade de autônoma, no comércio de alimentos para acompanhar a filha. Após cirurgia e quimioterapia, no final de 2003 a criança teve alta do tratamento e retornaram ao Rio de Janeiro. Em fevereiro de 2006, dois anos e 4 meses fora de tratamento, aconteceu a recidiva do Osteossarcoma. Mãe e filha retornaram a São Paulo e foi reiniciada a quimioterapia. Atualmente, mãe e filha moram em uma casa de apoio oferecida pela instituição e é a mãe o membro da família que acompanha a criança no processo de tratamento.

A coleta de dados foi orientada pelo método biográfico, que permitiu investigar a experiência das mães em determinado momento de sua vida, a partir de narrativas. Segundo o Interacionismo Interpretativo, a narrativa é uma estória que conta a sequência de eventos temporal e causal, que são significantes para o narrador e o pesquisador, que tem um começo, um meio e um fim. Nesta perspectiva, a entrevista requer estar trabalhando com uma série de informações que o pesquisador quer e deseja responder, na qual os significados, compreensões e interpretações não podem ser padronizados, ou seja, obtidas por um questionário formal e fixo.

Considerando que no estudo interpretativo o pesquisador busca descobrir como a problemática em torno da experiência é organizada, percebida, construída e atribuído significado pelos indivíduos em interação, a estratégia para coleta de dados foi a entrevista do tipo semi-estruturada, orientada pela questão norteadora: "Conte para mim sua estória de viver a experiência de ser mãe de uma criança com câncer." 
A fim de buscar profundidade e maior detalhamento da experiência e visando explorar o conjunto de processos psicoafetivos que se desenvolvem e se integram na experiência da mulher sendo mãe de uma criança com câncer, foram utilizadas outras questões:

- Como foi descobrir que seu filho tinha câncer?

- O que mudou na sua vida, como mãe, após o diagnóstico?

- Como você percebeu esta mudança?

- Como você vê sua vida de mãe antes e depois do diagnóstico?

- O que é importante para a senhora durante esta fase da vida de sua família?

As narrativas foram gravadas e transcritas na íntegra logo após a realização da entrevista.

\section{Análise dos dados}

Para análise dos dados obtidos através das narrativas das mães, seguimos os passos propostos pelo Interacionismo Interpretativo (Denzin, 1989):

1. Delimitação da questão em estudo, que requer habilidade de pensar reflexiva, histórica e biograficamente e consiste em formular a questão visando esclarecer como o processo ocorre na experiência, sofrendo influência da própria história do pesquisador.

2. Desconstrução e análise crítica das concepções prioritárias do fenômeno, ou seja, descobrir as concepções existentes com relação ao fenômeno em estudo, posicionar-se criticamente frente a estas concepções, e a seguir, apresentar pré-concepções e estudos anteriores que envolvem a compreensão do fenômeno. Além disso, é também trabalhar em um texto além de seu nível metodológico, mostrando tudo aquilo que foi dito, como o que não foi dito (Mohr, 1997)

3. Apreensão do fenômeno, localizado e situado no contexto; é apresentar as biografias, histórias de vida que abordam um fenômeno e localização das epifanias que envolvem o fenômeno em questão através de múltiplas histórias pessoais. 
4. Redução do fenômeno, isolando-o do contexto em que ele aconteceu através da localização e isolamento de frases chaves, interpretando-as e buscando significado para quem as pronunciou, explicitando a interpretação para, então, examinar o significado das frases e sua conexão com o fenômeno.

5. Construção do fenômeno, no qual se articulam novamente os dados através dos significados que emergiram na fase anterior, formulando-se uma nova estruturação do fenômeno, interpretando o processo como um todo e reconstruindo a experiência vivida.

6. Contextualização, que recoloca o fenômeno no contexto dos participantes, interpretando-o e proporcionando-Ihe significado.

Em um primeiro momento, após a transcrição das entrevistas, foram realizadas a leitura atenta e re-leitura das narrativas das mães, visando compreender a experiência como um todo e os significados atribuídos por elas à sua experiência.

Após essa leitura, as vivências relatadas foram quebradas em pequenas frases, através do que foi possível a identificação das unidades experienciais reveladas nas narrativas. Em seguida, em um processo minucioso de compreensão da carga semântica e das evidências contidas nas narrativas das mães, as unidades experienciais foram comparadas umas às outras de acordo com o seu significado na experiência, pelas suas similaridades e divergências. Posteriormente, as unidades conectadas pelo mesmo significado foram agrupadas.

O agrupamento das unidades experienciais permitiu a identificação de categorias e suas subcategorias, de temas e seus subtemas, que revelaram os significados e as vivências desveladas nos universos que compõe a experiência de ser mãe de uma criança com câncer. Assim, à luz dos temas, subtemas, categorias e subcategorias foram possíveis a compreensão da experiência e a identificação das epifanias, que serão apresentadas a seguir. 


\section{Resultados}


4.1. Compreendendo a experiência de ser mãe de uma criança com câncer

A análise minuciosa dos dados obtidos através das narrativas das mães será apresentada de acordo com as dimensões que compõe a experiência de ser mãe de uma criança com câncer. As unidades experienciais foram analisadas de acordo com seu significado na experiência da mãe. As unidades experienciais foram comparadas umas às outras, o que possibilitou categorizá-las, ou seja, agrupar as unidades experienciais conectadas pelo mesmo significado, permitindo-nos, assim, revelar dois temas: VIVER O TEMPO DA DOENÇA $\boldsymbol{A}_{2}$ que integra os subtemas Descobrir-se mãe de uma criança com câncer e Arriscar-se com o tratamento e VIVER UM TEMPO DE LUTA PELA VIDA DA CRIANÇA, que integra os subtemas Preparar-se para um tempo de batalha e Lutar pela vida da criança. Cada um dos subtemas é composto por categorias e subcategorias, que ofereceram a base para interpretação e compreensão da experiência de ser mãe de uma criança com câncer.

As dimensões da experiência de ser mãe de uma criança com câncer serão apresentadas na seguinte ordem: primeiramente, o tema VIVER $\boldsymbol{O}$ TEMPO DA DOENÇA, os dois subtemas, e suas respectivas categorias e subcategorias. Em seguida, apresentaremos o tema VIVER UM TEMPO DE LUTA PELA VIDA DA CRIANÇA, os subtemas e as categorias e subcategorias que os compõe e se integram na experiência de ser mãe de uma criança com câncer.

\section{VIVER O TEMPO DA DOENÇA}

VIVER O TEMPO DA DOENÇA representa a descoberta vivenciada pela mãe acerca da doença do seu filho e o início do tratamento oncológico. Representa também o tempo de se tornar mãe de criança com câncer e todas as circunstâncias desencadeadas por este evento. É quando a mãe percebe-se frente a uma situação de ameaça à vida do filho, de urgência em 
agir que a própria situação do câncer exige e de incertezas acerca do futuro que permeiam aquela situação, até então desconhecida. Ao descobrir a doença de seu filho, a mãe sai da condição de ser mãe de uma criança que ela conhecia como uma criança sadia para se tornar mãe de uma criança com câncer. Assim, a mãe percebe que é necessário aceitar-se como tal e adaptar-se a esta nova condição. Além disso, este tema representa a decisão da mãe em assumir todos os riscos e ameaça que a doença representa. Ela não sabe quais serão as conseqüências e nem tem a garantia de que o tratamento vai dar certo, sabe que se arriscar é sua única alternativa a fim de buscar a recuperação da saúde e integridade da criança. É arriscar-se mesmo diante de todas as incertezas e de toda a sensação de impotência por não poder livrar o filho do sofrimento que a doença the acarreta. É ver sua vida transformada de repente, sem aviso prévio, e muitas vezes não entender ao certo o que está acontecendo. Ao assumir os riscos e do tratamento, a mãe procura viver o presente, dia após dia, e fazer tudo o que pode ser feito para aliviar o sofrimento do filho. Ao mesmo tempo, é viver uma busca constante em acreditar no futuro livre deste sofrimento. Assim, VIVER O TEMPO DA DOENÇA revela uma conversa da mãe consigo mesma, um olhar direcionado para si vivendo agora uma situação nova como mãe, uma experiência que nunca havia se deparado anteriormente. $O$ trabalho interior da mãe começa pela aceitação de que 0 filho tem câncer e de sua nova condição como mãe e é continuamente permeado pelas incertezas inerentes à doença e à necessidade de afastar a ameaça de morte da criança.

Este tema é composto por dois subtemas: Descobrir-se mãe de uma criança com câncer e Arriscar-se com o tratamento. Como já mencionado, cada um deles é composto por categorias, representadas no diagrama 1. As categorias serão apresentadas após a definição de cada subtema, algumas compostas também por subcategorias, que serão descritas ao serem apresentadas as categorias. 


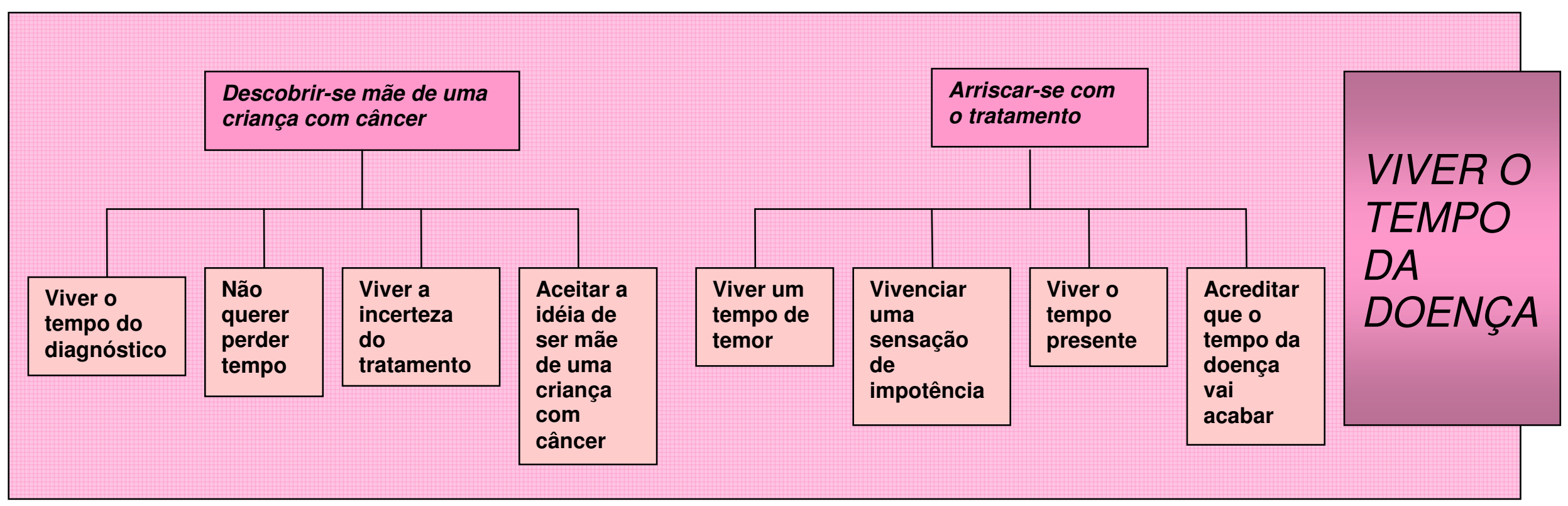

Diagrama 1 - Tema VIVER O TEMPO DA DOENÇA, seus subtemas Descobrir-se mãe de uma criança com câncer e Arriscar-se com o tratamento e as categorias que os compõe. 


\section{Descobrir-se mãe de uma criança com câncer}

Este subtema representa a difícil experiência da mãe que envolve receber a notícia de que seu filho está doente, bem como as vivências que permeiam o início do tratamento oncológico. Tal descoberta é permeada pelo choque inicial em se deparar com o diagnóstico de câncer do filho, pela mudança que acontece repentinamente na sua vida, bem como pela desestruturação na dinâmica familiar e nos papéis de cada um de seus membros que a doença acarreta por sua característica ameaçadora da doença. Descobrir-se mãe de uma criança com câncer envolve também a tentativa de retomar um estado de equilíbrio para poder estar junto ao filho, desenvolvendo o seu papel de mãe. Além disso, é viver a urgência em tomar uma atitude frente a essa ameaça e de correr contra o tempo, a fim de que o tratamento comece logo; é conviver com as incertezas e a insegurança, pois a mãe se depara com o universo desconhecido da doença. Descobrir-se mãe de uma criança com câncer é aceitar que a vida mudou e tentar adaptar-se a esta nova condição.

Descobrir-se mãe de uma criança com câncer é composto por quatro categorias: Viver o tempo do diagnóstico, Não querer perder tempo, Viver a incerteza do tratamento e Aceitar a idéia de ser mãe de uma criança com câncer. A primeira categoria, Viver o tempo do diagnóstico, é composta pelas subcategorias: Viver uma mudança inesperada, Viver uma ameaça à vida do filho, Tentar recuperar o equilíbrio. O subtema, as categorias e subcategorias que o compõe estão representadas no diagrama 2 . 


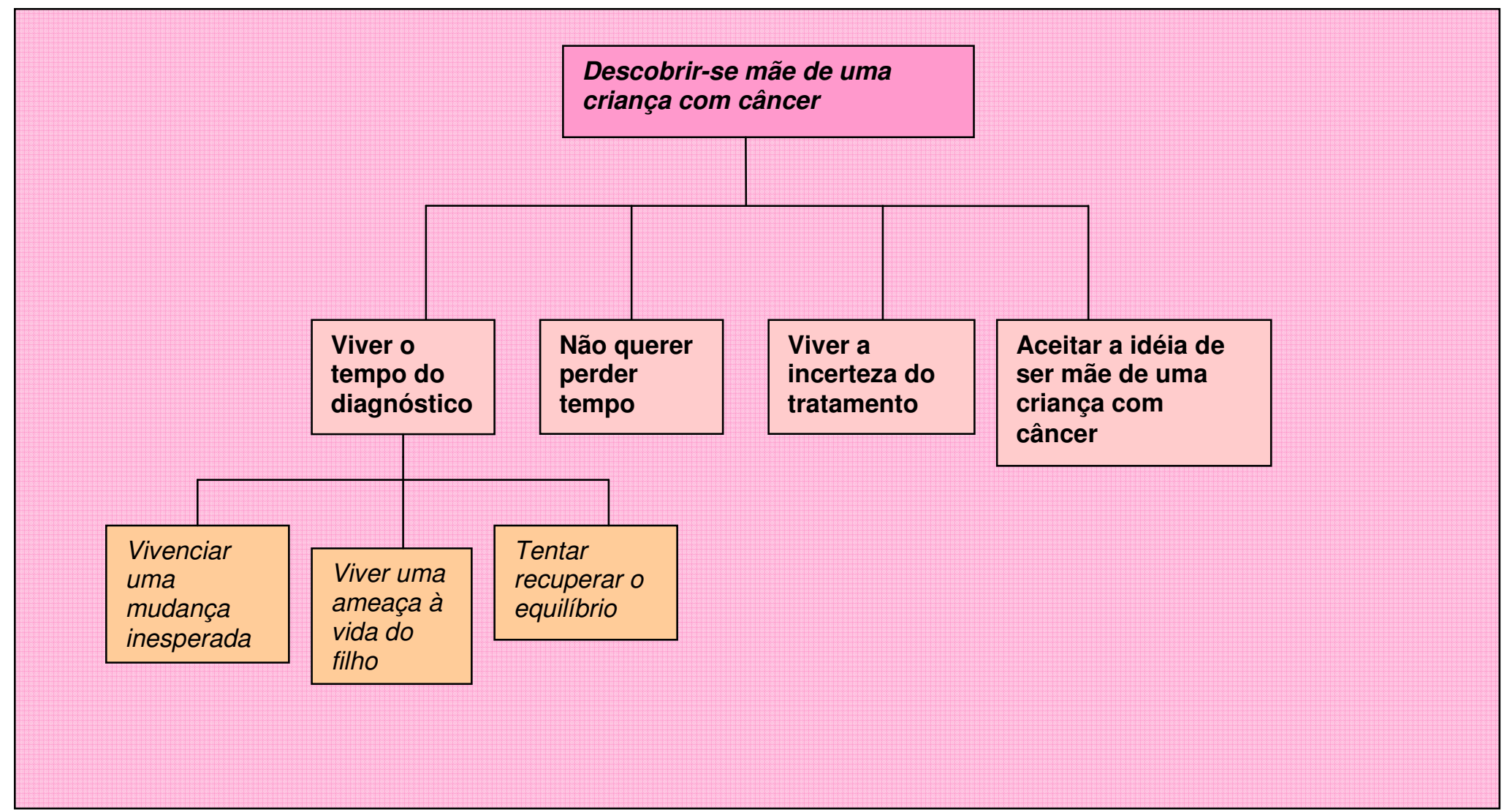

Diagrama 2: Subtema Descobrir-se mãe de uma criança com câncer, categorias e subcategorias que o compõe. 


\section{Viver o tempo do diagnóstico}

Esta categoria representa a sucessão de momentos vivenciados pela mãe, repletos de mudanças repentinas e de intensas transformações sua na vida e de sua família. Além disso, é viver um tempo de ameaça à vida da criança pela gravidade da doença, ainda tão obscura e incerta. Revela-se também na experiência como um tempo de desestruturação na sua vida, porém, a mãe procura não se entregar ao desespero, e tenta recuperar o equilíbrio visando dar forças para o filho doente e prosseguir a caminhada em um tempo que ela sabe que será um tempo difícil.

Receber a notícia de que seu filho tem câncer é Vivenciar uma mudança inesperada, algo que a mãe não quer acreditar ser verdade. A mãe não consegue ver o seu filho como uma criança doente, ou seja, ela não consegue neste momento associar o seu filho com a sua doença. É o choque de saber que o filho tem câncer e que esta doença não é uma doença qualquer, e sim, uma doença grave. A mãe não compreende porque isso aconteceu na sua vida e com seu filho, uma criança saudável, ativa e vivendo sua infância plenamente. $O$ câncer, que até então era uma doença distante, ou que ela não imaginava que pudesse um dia estar tão próxima, agora faz parte da sua existência. A doença invade sua vida e a vida de sua família de forma avassaladora, transformando-a repentinamente. Isso desperta na mãe uma sensação de fragilidade e de falta de controle. É quando a mãe e sua família iniciam a trajetória dolorosa de vivenciar o câncer do filho. É um momento de refletir, questionar e pensar sobre o tratamento e de muitas vezes, não saber para onde ir, por onde começar. É experienciar um vazio por não compreender ao certo o que está acontecendo, por perceber que sua vida já não é mais e não será como era antes; é experienciar um vazio por ter sua trajetória de vida, até então planejada e previsível, rompida pela doença e pela difícil experiência de vivenciar esta descoberta. 
Assim, o começo é muito doloroso porque eu não tinha conhecimento quase nenhum sobre câncer, principalmente em criança, já que a minha família não tem e a família do meu marido também não tem. E quando você na realidade, quando você recebe a notícia que você tem um filho com câncer, você já imagina que aquilo é o fim... e você leva isso por algum tempo. (Mãe 2)

Foi me sentir, foi assim... Quando eu recebi a notícia, o que meu filho tinha, que ele ia começar fazer o tratamento, eu me vi num buraco, e eu queria entrar dentro desse buraco e que ninguém me achasse! Porque eu acho que a gente nunca espera que vai acontecer com a gente. Apesar de hoje em dia a gente ver muitos casos, mas eu falo: "Poxa, com o meu filho, uma criança que sempre foi sadia, uma criança que nunca ficou internado, sabe, nasceu já normal, faz aquele exame do pezinho, tudo normal, como é que eu vou reagir perante essa situação?" (Mãe 3)

Quando eu abri o exame, eu comecei a chorar. O pai dela não queria que eu abrisse, mas eu abri. Pelo que li, eu sabia que não tava normal, porque tinha medida e tudo. Eu olhava para ela e chorava. (Mãe 4)

A gente não tem nem palavras, por que pra mim, quando eu soube, eu jamais, a gente não quer acreditar que é com a gente, né? Quer dizer, no que vai acontecer.

No início eu não acreditei, eu disse "Eu não acredito... Com a minha filha?". (Mãe 5)

E assim, choro, sofrimento, eu olhava pra ela e não via essa doença, porque a menina super boa, a A. com 8 meses ela tinha 12 quilos! Eu olhava cabeluda, nossa, um cabelão, tudo cheião, assim. "Gente, eu não sei, eu olho pra ela eu não enxergo essa doença". Era uma coisa assim, de uma hora pra outra a sua vida se transformar? (Mãe 6)

Ah, foi uma bomba! Foi uma bomba realmente que caiu na cabeça da gente, da família inteira, né? Ninguém imaginava uma situação dessa... Mas foi muito desesperador, realmente, a gente é ser humano, mesmo estando com Deus, mas a gente sente porque é difícil, e é um tratamento doloroso, então tem muita coisa que vem na cabeça, assim, que a gente fica meio que, meio que preocupado demais. (Mãe 7)

Ao mesmo tempo em que percebe sua vida transformada inesperadamente pela doença, a mãe percebe que a vida do seu filho está ameaçada. Viver uma ameaça à vida do filho é perceber que o futuro projetado de acordo com as expectativas da própria criança e da família 
agora pode não acontecer. Além disso, apesar de não conseguir ver seu filho como uma criança doente, é vivenciar o temor da incerteza de voltar a ver o seu filho saudável e brincando, vivendo seu tempo de criança, o que gera sentimentos de angústia e desorientação. Saber que o filho tem câncer e perceber que sua vida está ameaçada remete a mãe a sentimentos de tristeza e de uma perda antecipada, uma sensação de que o seu tempo como mãe daquela criança pode acabar. Essa sensação permanece com ela durante um tempo, por não conseguir ainda acreditar que a doença pode ter cura. A ameaça que a doença representa à vida da criança remete a uma reflexão sobre as suas condutas como mãe até então, e envolve questionamentos acerca da sua dedicação, proximidade e atenção à criança antes da doença, dos seus possíveis erros como mãe e do porquê aquilo aconteceu com ela e com seu filho. Viver uma ameaça à vida do filho é viver a incerteza do futuro é não ter controle sobre o dia de amanhã.

Ela ficava, ela é muito sapeca, a A., entendeu? E ela ficava deitadinha, com a boca toda cheia de ferida, com tantos dias sem comer, sem beber água, aquela carinha triste, foi pior essa época do que a época quando eu soube o que era realmente a doença dela. Pra mim foi a pior época. Eu pensei que não ia ver mais minha filha sorrindo, brincando, do jeito que ela é. Porque ela é assim, ela é arteira o dia inteiro, sabe, ela não pára, ela pula, ela brinca, só quando está fazendo quimio, que aí dá uma caída nela, mas... A não ser, as meninas ficam doidinha! (Mãe 1)

É assim, é... Viver o aprendizado porque no começo, você se sente... É um choque, é um choque pra você, é um choque pra família inteira. E aí com o tempo você passa, você é uma pessoa apressada, você prepara o futuro dos filhos, você imagina que o filho vai estudar, que o filho vai fazer uma faculdade, que o filho é isso, que o filho é aquilo... De repente você se vê nessa situação em que tem essas... tem essas... alguma coisa que vai impedir de você concretizar aquilo que você imaginou! De cara você pensa logo assim. E depois como você não tem muito conhecimento, quando você é mãe e recebe a notícia que seu filho está com câncer, aí você já imagina também que: "Pronto, a minha vida acabou, junto com a dele".(Mãe 2)

É um peso, sabe, parece que cai, assim, em cima de você. Porque que nem eu falei, no meu caso eu sempre trabalhei fora. Eu sempre trabalhei fora e, assim, não acompanhava $o$ 
meu filho, 24 horas, entendeu? Então a primeira pergunta que eu fiz para mim mesma foi: "Onde será que eu errei? O que eu deixei de fazer para essa criança que foi chegar nesse ponto de uma leucemia?"... Porque assim, a gente leiga no assunto, a primeira coisa que eu sempre soube é que talvez viesse de uma anemia. Essa leucemia foi uma anemia que não cuidou direito e que virou leucemia. Mas ele nunca teve anemia! Levava no posto, tudo assim certinho, era sempre "está jóia, está com o peso ideal, está crescendo, conforme tem que crescer", essas consultas de rotina do mês, e nunca dava nada diferente... De repente chega e fala que é uma leucemia? Você perde tudo, você não sabe o que você faz. (Mãe 3)

Aí, Nossa Senhora! Aí o mundo acaba, você fica sem chão, você não sabe o que pensar, parece que na hora, pra falar a verdade, a gente, é como se a gente levasse assim, como se fosse falar assim: "A sua filha, já era..." Na hora, a gente tem essa sensação, porque você não sabe, é uma doença tão grave, tão séria, que pode levar a isso mesmo, também... (Mãe 6)

Apesar das mudanças repentinas e da ameaça à vida do filho ao descobrir-se mãe de uma criança com câncer, a mãe busca Tentar recuperar o equilíbrio. A doença é algo que a desestrutura, mas ela busca uma sustentação no momento difícil e crítico em que parece que sua estrutura desabou. Ela procura não se desesperar, pois isso não a ajudaria, e tenta recuperar a calma. Desesperar-se não resolveria a situação difícil que está vivendo, pelo contrário. Ela sabe que precisa lutar, e o desespero diminuiria suas forças para estar junto ao filho.

Então, é... eu falei assim pra minha irmã, minha irmã veio e falou pra mim, esse pessoal que tava lá em casa, eu falei assim: "Se eu me desesperar resolver o caso da minha filha, eu me desespero agora! Eu viro meus cabelos, eu dou uma de louca agora, mas não vai resolver o caso dela!" Vai resolver o caso dela? Não vai! Eu vou deixar ela mais desesperada ainda, e eu tenho que ter força pra lutar junto com ela. (Mãe 1)

Que já pensou uma mãe ela se sentir totalmente fora de si, o que vai fazer, o que deixa de fazer, e acompanhando a criança? De que forma você ia acompanhar? Se nem você sentia, você não sabia como receber aquela notícia, depois que recebe então... Como você poder ajudar uma criança se você não está bem, se você não está com seu pé no chão ali, sentindo que pode fazer algo? (Mãe 3) 


\section{Não querer perder tempo}

Ao Descobrir-se mãe de uma criança com câncer, a mãe vivencia uma fase de urgência e pressa em iniciar o tratamento. Apesar da sensação de fragilidade e de falta de controle ocasionada pela transformação que a doença acarreta, a mãe sabe que a vida da sua criança está ameaçada. A mãe não pode parar e ficar esperando o que vai acontecer, ao contrário: ela precisa agir. A mãe sabe que pode fazer algo e que alguém pode ajudá-la nesse momento difícil. Assim, ela quer chegar logo ao hospital e deseja que o tratamento se inicie o mais breve possível. A mãe não quer perder nenhum segundo mediante a situação de saber que o filho tem câncer e quer ter a sensação de que está na frente da doença que está avançando; é como se o seu tempo precisasse ser mais rápido do que o tempo da doença.

Quando o pai dela chegou, eu falei que eu tinha lido e que não ia contar para ele, mas que no outro dia a gente ia para o hospital. Aí ele pegou e exame, viu o que estava escrito e falou: "Vamos para o hospital agora". (Mãe 4)

Até então, a doutora veio no outro dia e falou "Olha, mãe, eu não sei que tipo de tratamento ela vai fazer, mas eu vou te encaminhar pra um lugar que só trata disso, de crianças e adolescentes, um hospital muito bom". Aí encaminhou pra cá e a gente, imediatamente, sabe, eu não queria perder nenhum segundo que fosse. Queria logo que entrasse em tratamento, desesperada pra isso, entra, entra, entra. Por mim, na primeira consulta, já fazia! (Mãe 6)

Mas, logo que a gente soube também não perdeu tempo, sabe, procuramos logo um médico pra poder ver como é que ia fazer... Ela foi num ortopedista, e o ortopedista falou que era

pra gente procurar um oncologista, o mais rápido possível e no mesmo dia a gente conseguiu marcar uma consulta com o oncologista pra ver. Ele passou vários exames, e ela já diagnosticou. Daí pra cá a gente não perdeu tempo. Porque a gente sabe que essa doença ela corre contra o tempo, a gente, ela é muito rápida, então se a gente bobear ela passa a frente e a gente fica pra trás, então a gente tem que ir na frente dela. (Mãe 7) 


\section{Viver a incerteza do tratamento}

Esta categoria revela a insegurança vivenciada pela mãe que permeia o momento da chegada no hospital, a primeira consulta, a primeira quimioterapia. A mãe tem dúvidas sobre a doença, sobre como cuidar da criança, como agir mediante a nova situação em que se encontra e as novas demandas de cuidado que o tratamento oncológico exige. A mãe experiencia as dúvidas e a insegurança referentes às necessidades ocasionadas pela terapêutica. Por não ter conhecimento suficiente sobre o câncer e o seu tratamento, ela não sabe se o que está fazendo é certo, se sua maneira de agir e cuidar do filho está correta. A mãe percebe-se tendo dúvidas sobre como cuidar do filho, algo que ela sempre fez como mãe, sobre como será o tratamento, e também sem saber para onde aquela situação a levará. Ela vivencia o medo da quimioterapia e seus efeitos, algo que a deixa horrorizada e apreensiva; vivencia o medo de que algo dê errado com o tratamento, colocando seu filho em uma situação de risco ainda maior, agravando seu estado; o medo do próprio ambiente hospitalar, tão desconhecido, novo e assustador para ela. Neste tempo de incerteza e insegurança, a mãe volta-se totalmente para o tratamento do filho, concentrando-se integralmente nas suas necessidades e também tentando retomar algum controle da situação, evitando que algo de errado aconteça.

Quando eu vim aqui, a primeira vez, que eu fiquei olhando tudo assim, eu não tinha noção de câncer. Eu não tinha, não vou falar que tinha porque eu não tinha, na minha família nunca teve ninguém com isso... Ninguém, nem meus avós que já morreram, e eu nunca conheci, nunca convivi com ninguém com essa doença. Tinha uma vizinha minha, mas eu não convivi com ela, então eu não tinha noção de câncer, eu não tinha noção assim de um tratamento, como era... Eu só ouvia as mães falarem, sobre quimioterapia. Aquilo já me deixava, sabe, aquilo que eu escutava já me deixava horrorizada. (Mãe 1)

Como eu falei, no começo a gente se concentra praticamente vinte e quatro horas no tratamento. O medo de alguma coisa dar errado é enorme! A gente se sente insegura, porque tudo é novo, né, você busca informação, mas tudo é novo e existe aquela coisa de 
você ter o diagnóstico e você ainda não acreditar muito... é futuro muito incerto na verdade! O medo sempre aparece, mas... com o tempo é que você vai perceber o quanto você viveu esse período mais pra o que tava doente, deixando o restante de lado... (Mãe 2)

E nesse período de tratamento, foi assim... Eu me senti totalmente assim, como eu vou te dizer, sem os pés no chão! Me senti totalmente perdida sobre a situação. Como cuidar, o que fazer pra melhorar. Porque primeira coisa mexe muito com o sistema psicológico, tanto meu como dele, a criança fica mais, assim, agressiva, que a gente tem que estar tendo muita paciência pra tudo. Pelo decorrer do tratamento, foi havendo assim, dificuldades, entendeu, o que eu posso fazer pra estar ajudando? Será que a minha medida vai estar certa ou não? (Mãe 3)

No começo, assim, não foi muito bem, não, porque até aceitar a idéia, você não sabe como, o que vai vir pra frente... Porque geralmente, assim, o pessoal escuta coisas horríveis dessa doença, né? Eu até então não sabia como é que ia ser, e era totalmente ignorante a respeito da doença e tudo. Então, assim, pra mim, foi um impacto muito grande. Eu não sabia, fiquei totalmente sem chão, e não sabia como que ia ser. (Mãe 6)

Aí eu fiquei pensando assim: "Nossa...". Na hora você assim, você fica sem rumo, foi uma noite que eu não dormi, uma dor de cabeça explodindo, explodindo, não parava, tomava remédio e não passava essa dor de cabeça, eu olhava assim pra ela, ela dormindo, ficava imaginando um monte de coisa, "Meu Deus, como é que vai ser daqui pra frente, como é

que é esse tratamento, será que ela vai passar mal?" Você não sabe, eu mesmo era totalmente ignorante, "Como é que vai ser, será que ela vai vencer?", e ficava pensando mil coisas na cabeça... (Mãe 6)

\section{Aceitar a idéia de ser mãe de uma criança com câncer}

Representa um tempo que se faz necessário assumir não somente a doença e as mudanças que se desencadeiam a partir do diagnóstico, mas sim, um tempo para aceitar a doença na vida do seu filho e na sua vida. Aceitar-se enquanto mãe de uma criança com câncer permite que ela assuma que seu filho está vivenciando a doença, não escondendo o que está acontecendo das outras pessoas que com ela e com a criança convivem e acostumando-se com a sua nova situação, uma situação difícil, mas que é necessário se adaptar para prosseguir na sua trajetória. 
Eu acho que também é importante a aceitação, principalmente da mãe. E não esconder de ninguém. Todo mundo aceita, gosta dela e isso é importante, senão a criança acaba ficando mais constrangida. (Mãe 4)

Aí, veio aquela coisa de diagnóstico, de transferência de um hospital pro outro e aqui, assim, tendo contato com outras mães que eu fui sabendo e me adaptando com a idéia, de ser, mãe... Muitas crianças que hoje estão curadas e outras infelizmente não conseguem, mas aí cada caso é um caso. Mas pra mim assim, agora a gente está acostumando com a situação, mas no começo, pra mim foi muito, super difícil, é difícil até hoje, mas no começo é mais... Pra mim foi assim... (Mãe 6) 


\section{Arriscar-se com o tratamento}

Arriscar-se no tratamento é o subtema que representa o primeiro passo da mãe na luta contra o câncer do filho. É viver um tempo da doença em que se arriscar é sua única opção para não perder a criança, apesar de toda insegurança ocasionada pela doença. É assumir todos os riscos frente à ameaça que a doença representa para a vida do seu filho, apesar de ainda não estar claro todos os elementos que envolvem essa batalha, e nem qual será o seu resultado. Além disso, é um tempo da doença em que a mãe vivencia o temor de não saber o que vai acontecer no momento seguinte e precisa estar alerta e disponível para qualquer situação emergencial que venha a ocorrer. Ao arriscar-se com o tratamento neste tempo de doença, a mãe experiencia uma sensação de impotência por não ser capaz de livrar o filho do sofrimento. Ao arriscar-se com o tratamento, jogando todas as suas cartas na mesa, a mãe vive um tempo de centrar-se somente no tempo presente. Porém, ao mesmo tempo em que sua atenção está centrada no presente, valorizando as experiências dia após dia e não utilizando suas energias para fazer planos futuros, a mãe se permite pensar em um tempo sem a doença. Neste sentido, permite também que a esperança venha a crescer e ser um elemento fundamental no tempo em que os riscos permeiam a vida de seu filho.

Arriscar-se com o tratamento é composto por quatro categorias: Viver um tempo de temor, Vivenciar uma sensação de impotência, Viver o tempo presente e Acreditar que o tempo da doença vai acabar. $O$ subtema e suas categorias estão representados no diagrama 3. 


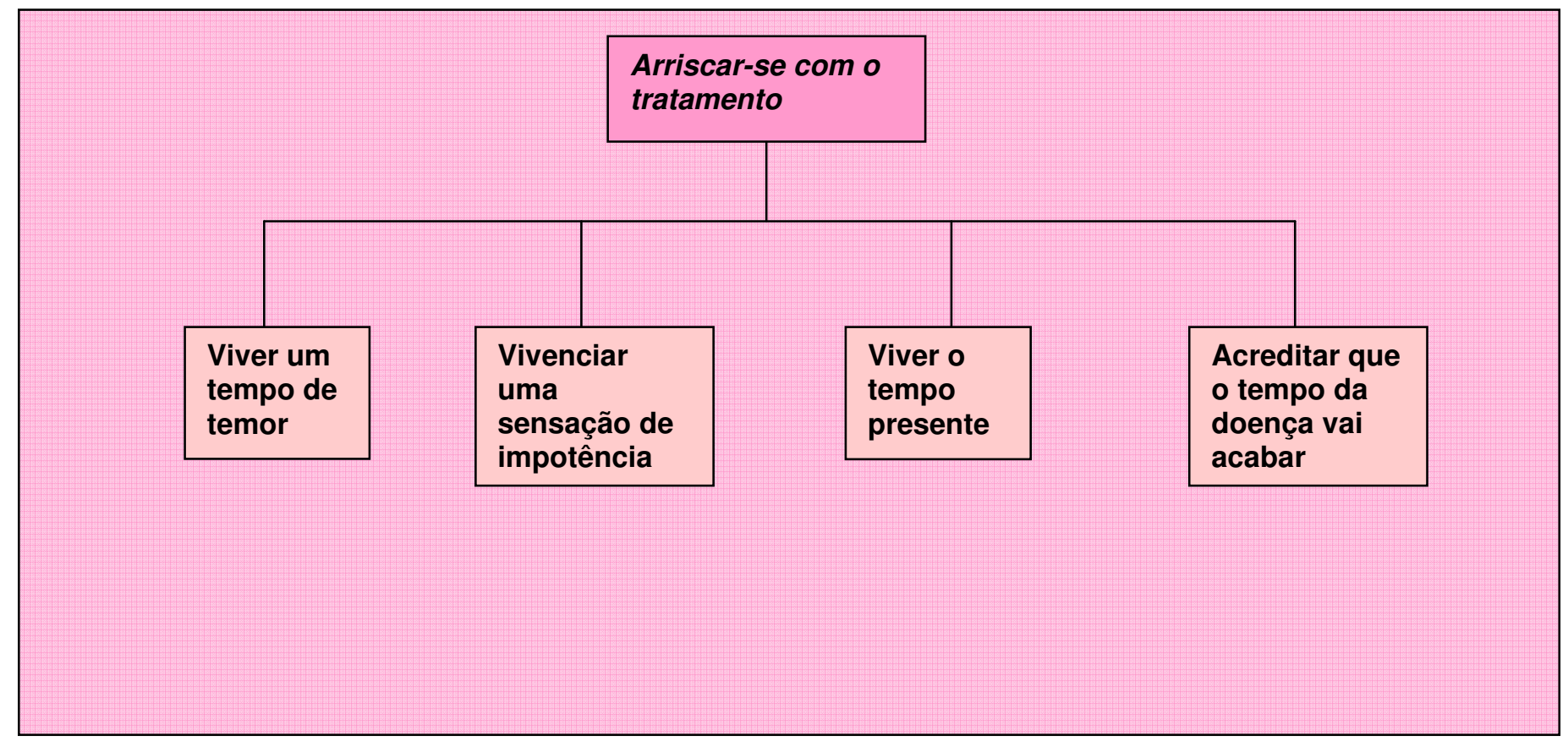

Diagrama 3: Subtema Arriscar-se com o tratamento, categorias e subcategorias que o compõe. 


\section{Viver um tempo de temor}

Quando a mãe decide arriscar-se com o tratamento contra o câncer do filho, ela passa a Viver um tempo de temor, que representa um tempo de escuridão. A mãe sai de uma condição de vida e passa a viver entre a casa e o hospital. Isso significa viver sob a apreensão e a ansiedade de que, a qualquer momento, durante o dia ou durante a madrugada, a vida do seu filho possa estar em risco e seja necessário agir. Viver um tempo de temor revela que a vida planejada e previsível, na qual existia um controle acerca da situação, não existe mais. Agora, neste tempo de temor, o que vai acontecer no momento seguinte é uma dúvida. É um tempo em que sair de casa passa a ser menos freqüente, o que gera uma sensação de ser prisioneiro da doença, e no qual os relacionamentos ficam mais limitados e estreitos. Ao mesmo tempo, ir ao hospital é algo que acontece rotineiramente e, às vezes, diariamente, sendo preciso abandonar as demais atividades para levar a criança para um atendimento. A vida da mãe e da família transforma-se em uma correria, e ela precisa agir a fim de proteger sua criança do perigo que a doença pode lhe trazer. Assim, viver um tempo de temor é vivenciar um tempo da doença que põe a vida do seu filho em risco e justamente por isso é necessário arriscar-se com o tratamento estando a todo tempo disponível para ajudá-la.

O maior problema de viver aqui é assim, eu não me sinto... eu não saio, nos fins de semana, dificilmente eu saio de casa a não ser que na casa de algum parente. Eu me sinto meio presa aqui! Eu não consegui em S.P. fazer amizade, é como se fosse um mundo que você vive mais fechada, é você e sua família! Eu não consegui fazer amizades, tipo sair ou viajar um pouco com alguém, a gente vive mais, esses quatro anos dentro de casa. Fim de semana quase que a gente não sai.(Mãe 2)

Então, assim, pra mim a correria é essa, é tipo assim, estar de noite, na madrugada, dormindo, a A. acordar com febre, e ter que vir pro hospital. Já ficar preocupada porque que origem de febre é essa, de onde está vindo? (...) Aí, a correria é essa, de tratamento pensar "Está com febre, vamos pro médico", "Ah, será que ela vai ficar boa hoje?", de viver naquela ansiedade, aquela apreensão, tanto é que engordei 8 quilos, do começo do tratamento pra 
cá, porque é muita ansiedade, muita correria, e meu marido também. Pra ele, porque ele trabalha a noite... Ele trabalha a noite... Hoje mesmo, amanheceu o dia, chegou 6 horas em casa, pegou a gente, veio pro hospital. Aí já pega um pouco de trânsito, porque eu sei que ele não dormiu, está com cara de cansado, aí deixa a gente aqui, vai pra casa e dorme até a hora de eu ligar de volta pra ele vir, pra poder trabalhar de noite. Não fica corrido só pra mim, mas pra ele também. Às vezes tem que deixar tudo lá no serviço pra poder estar correndo atrás. Ele é nosso meio de transporte, se acontecer alguma coisa, ele que vem, ele que leva, ele que trás. Então sai correndo, de onde ele tiver pra vir levar pro hospital. Nossa vida é essa agora: hospital-casa, hospital-casa. Quando tem um tempo assim, pra lazer, que ela está bem, que a gente está tudo bem, a gente aproveita. Eu concordo, assim, de estar saindo pra aliviar o estresse dela e da gente também. (Mãe 6)

Então é aquela correria, corre pra um lado, corre pro outro, aí quando dá uma febre, corre pro hospital... Liga, "Ah, a A. deu febre", "Ah, traz pro hospital", vem! "A plaqueta tá baixa, vem pro hospital", "Vem pro hospital!". É aquela correria, de acordar: "Nossa, hoje eu não tenho consulta, ai que bom!", "Ah, hoje eu tenho", "Vou ficar quinze dias sem vir pro hospital, ah, que bom!" É aquela, coisa, desse jeito. (Mãe 6)

\section{Vivenciar uma sensação de impotência}

A decisão da mãe em se arriscar com o tratamento significa não somente viver a apreensão que envolve viver um tempo de temor, mas também conviver uma sensação de impotência. Representa o sofrimento experienciado pela mãe ao ver seu filho sofrer ou mesmo por perceber que há certas coisas que gostaria de fazer para aliviar a dor da sua criança que não estão ao seu alcance. Esta é uma situação difícil e entristecedora, pois presenciar o sofrimento do filho é algo que ela não quer que aconteça, desejando livrá-lo daquilo. Ela se dispõe a trocar de lugar com o filho, assumindo a sua dor se fosse possível, ou querer tirar a doença da criança com as próprias mãos. Porém, ela sabe que isso pode acontecer, o que the traz uma sensação de impotência. Ao presenciar junto ao filho todas as experiências deste tempo de doença, a mãe vivencia o sofrimento do filho como seu próprio sofrimento. Assim, mesmo não sendo com ela, é sentir a mesma dor que o filho sente. Vivenciar a sensação de impotência ao 


\section{presenciar o sofrimento do filho é considerado uma das piores vivências desta experiência.}

Quando ela teve a mucosite, quatorze dias lá na cama. Aí quem teve que ter força de leão fui eu! Pra segurar a barra porque ela ficou muito revoltada, tinha dia que, teve vez que três enfermeiros teve que segurar ela, ela ficou revoltada demais... Aí ela queria comer, ela tinha fome, não agüentava. Por que a mucosite dela foi muito feia, muito feia mesmo. E em casa, também, ela teve alta e ficou mais quatorze dias com a boca ferida. Em casa ela quebrava as coisas, você tentava dar alguma coisa pra ela comer, ela jogava longe. Então teve muita dificuldade nesse tempo, foi a pior parte, eu não desejo pro meu maior inimigo. Ela chorava a noite, ela gritava. (Mãe 1)

É difícil porque assim, quando você tem um filho que tem uma febre, uma gripe, você já fica desesperado. É doloroso assim, porque a vontade que a gente tem é de tirar a doença com a mão, e a gente sabe que não é possível. E o tratamento é sofrido, principalmente leucemia e você fica meio impotente na situação, de ver ele sofrer e não poder ajudar. A única ajuda que a gente pode dar é procurar ser forte, que nem sempre é fácil, e se manter firme, né?(...) É assim... Quando a gente diz que gostaria de tirar a doença com a mão é porque quando você tem um filho você quer proteger ele acima de qualquer coisa. Então se de repente você vê seu filho sofrendo, se você pudesse oferecer um braço pra ser furado no lugar dele, oferecer, se fosse fazer uma cirurgia você faria no lugar dele. É assim que a gente se sente, gostaria que a coisa fosse em você e não nele.

Então por isso que quando você recebe um diagnóstico assim, principalmente de uma doença tão séria, então você diz assim: "eu gostaria de tirar com a mão". Tirar com a mão é tirar o sofrimento, é não ver sofrer... Quando você tem filho que vê ele crescendo, você não

se prepara pra esse tipo de coisa. Você pensa em tudo menos nisso, essa é que é a realidade. (Mãe 2)

Quando você vivencia junto com a criança o que está passando, você acaba adquirindo pra você também aquilo. Eu não sentia porque não me picava, não fazia o que fazia com ele, mas no coração eu sentia a mesma dor que meu filho, de ver ele ali, de estar fazendo, de estar colocando um procedimento nele, eu também sentia dor por dentro, que eu acho que toda mãe sente, entendeu?(Mãe 3)

Se cada picada pudesse dar em mim, se eu pudesse estar no lugar dela... Mas infelizmente, né? Tem que ser... Tem que ser ela que tem que passar... E eu também, né? Eu como mãe e ela como filha... É desse jeito que eu me vejo... (Mãe 6) 


\section{Viver o tempo presente}

Para que seja possível viver o tempo da doença arriscando-se com o tratamento, vivenciando um tempo de temor e de sensação de impotência, é necessário viver cada momento da experiência. Isso significa viver um dia após o outro, tendo como foco o hoje, o agora. Envolve uma decisão da mãe sobre como usar melhor o tempo que ela tem. Assim, a mãe decide que vai utilizar seu tempo de forma diferente, fazendo tudo que for possível para a criança. Isso permite aprender com a experiência de ter um filho vivenciando o câncer, não se apegando ao que já se passou, o que torna o dia de hoje cada vez mais importante. Ela não faz mais planos para o futuro, pois o futuro ainda não pode ser vivido. O passado é algo que permanece na sua memória e que jamais será esquecido. Porém, ela não vive em função do passado e do que sofreu com o filho, pois isso já se foi e nem do futuro, que ainda não lhe pertence; a mãe vive em função de um dia após o outro, sendo cada dia uma nova oportunidade para lutar. Viver o presente em um tempo de arriscar-se com o tratamento é um aprendizado, uma habilidade que ela desenvolve e que a permite aprender a cada dia algo novo enquanto mãe.

E você passa a ser mais tolerante, mais paciente, e a planejar menos o futuro! Você passa a ver mais o hoje, o futuro não interessa tanto quanto antes de você ter uma notícia assim! Isso é um aprendizado! (Mãe 2)

Esquecer? Jamais a gente vai esquecer tudo isso... Porque fica gravado na memória, no coração, cada momento que passou, tudo que foi passado, mas assim... O bom disso tudo é pôr as partes boas, o que trouxe de bom pra gente. (Mãe 3)

Agora eu não faço mais planos, eu vivo um dia de cada vez... Porque às vezes você faz um plano e Deus tem outro.(Mãe 4)

Então, a gente procura pensar muito assim, daqui pra frente! Porque eu procuro colocar na minha cabeça é assim, deixe pra trás o que já passou, pra mim já passou, agora é um dia 
após o outro, vamos ver no que vai dar, não sei quais os planos de Deus, mas a gente está vivendo do jeito que tem que ser. Teria que ser assim, né?(Mãe 6)

Você tem em mente: "Ah, meu filho vai crescer, tudo, tal, tudo, vai ser isso, isso, isso". Hoje pra mim não, cada dia é uma vitória, entendeu? Cada dia hoje, eu acho que tem mais importância do que antes... Não que antes não teria, mas hoje eu acho que é uma coisa mais forte, sei lá, dentro de mim... Hoje é uma coisa mais forte, parece que eu amo mais, entendeu? Eu vivo em função deles! Aí quando eu estou mal assim, "Ah, a A. está mal", "A A. hoje está ruim, mas ela vai ficar boa, ela está tomando antibiótico, ela vai melhorar, e o outro (filho), está bem aqui, olhando pra mim, precisando de mim, então vamos levantar essa cabeça e vamos seguir em frente". (Mãe 6)

\section{Acreditar que o tempo da doença vai acabar}

Ao mesmo tempo em que a mãe aprende a viver um dia de cada vez para que possa oferecer o melhor e tudo que seu filho precisar, aproveitando o seu tempo com ele, ela também é capaz de ter esperança que este tempo terá um fim. Isso significa que a mãe acredita que tudo aquilo que estão vivendo, ela e sua criança, vai terminar bem e que vão vencer a luta contra a doença. É pensar e viver o presente, mas projetando no futuro a confiança de que a criança pode ser curada, que um dia ela estará a salvo da doença. A mãe acredita que a cura é possível, tem fé que tudo vai dar certo e que terá a recompensa pela sua luta: ver o filho bem. Isso permite que a mãe possa vislumbrar a felicidade para o seu filho e sua família longe da doença. Não significa viver em função do futuro, pelo contrário. A mãe vive em função do presente, um presente no qual faz parte acreditar em um tempo sem a doença, nunca perdendo a esperança. A esperança que seu filho vai vencer a doença é a âncora para que ela não se perca e não desanime, e que motiva todas as suas decisões como mãe, apesar das barreiras enfrentadas dia após dia. Fé, confiança e esperança são elementos fundamentais para prosseguir nesta luta e acreditar que o tempo de doença acabará. 
O que é importante? Pra mim? Com sinceridade? É que ela fique boa, só isso. Pra mim, é a única coisa que eu quero na minha vida, que ela fique curada!

Eu tenho fé em Deus nisso, que ela vai ficar boa. Pra mim, a única coisa que importa agora no momento é isso. Que ela fique boa, que nem agora ela fez, o tumor sumiu, né? Então eles fizeram uma biópsia no local, quarta-feira passada, pra saber se a quimio matou a raiz, né? E só vai sair o resultado, por isso ela está fazendo quimio, ainda porque o resultado não saiu. Dra. E. falou que enquanto não tiver o resultado tem que fazer né? Só sai a semana que vem o resultado da biópsia, aí tendo, ela para o tratamento e fica para o controle. E é isso aí, a única coisa que eu quero é que ela fique boa, só isso.

(Mãe 1)

Então acho que o importante é isso, você passar, ser o mais transparente o possível, e levar a sério em primeiro lugar, eu acho que a mãe e o pai têm que levar a sério esse tratamento, saber que é um tratamento sério, mas que hoje graças a Deus, a medicina está bem avançada e a gente tem uma esperança. Eu acho que se tiver um pingo de esperança, a gente tem que se agarrar nela, confiar em Deus e ver que um dia a gente vai ganhar, vai vencer tudo isso e ter a vitória. (Mãe 3)

Ah, o que eu queria deixar assim sabe, não sei como mensagem, não sei, pra todos que passam por isso é que nunca deixem de ter esse pinguinho de esperança. Por que por mais que você veja uma escuridão, esse túnel, vamos dizer assim, de coisas só ruins, de coisas que você não tem esperança, que você pode sim acreditar, que lá no fim, por tudo que você passar, mas lá no fim sempre vai ter uma luz. E que essa luz vai ser de grandeza, vai trazer muita alegria, tudo aquilo que um dia você achar que está perdido, que nada é perdido, que basta você buscar, você confiar, você crer, se entregar, que tudo vai vencer, que tudo pode.

(Mãe 3)

Então, eu peço assim, hoje, é que ela fique muito bem, nossa! Que ela saia do tratamento curada, totalmente dessa doença. E que a gente fique sempre saudável vivendo daqui pra frente. O que passou, passou! Entendeu? Pra mim, o mais importante hoje é isso, é a cura dela, é a gente viver, feliz pra sempre... Essa é a minha vontade... O que eu quero é que agora dê tudo certo, ela vai fazer os exames de novo. Tenho fé que vai dar tudo certo. Ela vai ficar fora de tratamento, e a gente só vai vir aqui pra controle, pra ver as pessoas que ficaram, os enfermeiros e os médicos, só pra dar um "alô"... Só pra dar um "alô" e agradecer, só tenho a agradecer agora. Está bem, graças a Deus deu certo, está respondendo bem ao tratamento e daqui pra frente, que nem eu te falei. Com saúde, e indo pra frente. Enfrentamos, e se tiver que enfrentar algumas barreiras também, tem que enfrentar, né? Não andar pra trás, tem andar pra frente... É assim que eu penso... 
É isso que eu tento passar pra ela, sempre pensar no melhor, que vai dar certo, porque realmente essa doença ela é muito cruel. Muito cruel, quando a gente pensa que está tudo bem, ela vem e pega a gente de novo, mas a gente tem que estar forte pra lutar de novo contra ela, entendeu?(...) Porque eu procuro assim, eu sou uma pessoa muito positiva, sempre pensando o melhor, sempre pensando que vai dar tudo certo. Não vou te dizer que é fácil, não é fácil. Mas a luta é grande, mas a gente tem que estar sempre com força, até para dar força pra eles, porque eles precisam. Se eles, as crianças verem que a gente está triste, pessimistas, aí eles acabam achando que "poxa, é o fim do mundo, né? Não tem jeito..." (Mãe 7) 


\section{VIVER UM TEMPO DE LUTA PELA VIDA DA CRIANÇA}

Este tema representa a dimensão dos comportamentos da mãe que se expressam nas interações consigo mesma, com a criança e com todos os elementos envolvidos na experiência de doença do seu filho, evidenciando a construção do seu papel de mãe de uma criança com câncer. Viver um tempo de luta pela vida da criança inicia-se quando a mãe se prepara para este tempo, no qual ela busca conhecer a doença do filho, buscando os subsídios necessários para que possa lutar. É como se este conhecimento Ihe proporcionasse mais armas para combater o câncer, seu inimigo. Além disso, se ao preparar para um tempo de batalha para viver a luta pela vida da criança, a mãe precisa fazer escolhas, reavaliando e delimitando prioridades e redefinindo papéis. Ao se preparar para a batalha, a mãe decide que a prioridade para a sua vida neste momento é o filho com câncer, e, muitas vezes, é preciso ausentar-se da família em uma busca incansável de um lugar seguro onde possam lutar. Estando preparada, a mãe então vive a luta em si, expressando um conjunto de comportamentos tendo como foco a manutenção da vida da criança frente à ameaça que a doença representa. Expressa dimensões do papel de mãe, como a proximidade e disponibilidade para com o filho, a necessidade de protegê-lo e o suporte que the é oferecido baseado nas suas necessidades frente a doença e o tratamento. Além disso, é fortalecer-se e fortalecer seu filho, pois é uma luta que os consome enquanto pessoas. Tudo isso faz com que a mãe se sinta doando-se por completo, dando tudo de si para o filho e podendo viver a experiência de ser mãe de uma criança com câncer em sua plenitude.

VIVER UM TEMPO DE LUTA PELA VIDA DA CRIANÇA é composto por dois subtemas: Preparar-se para um tempo de batalha e Lutar pela vida da criança, e as categorias de cada um deles estão representadas no diagrama 4. 


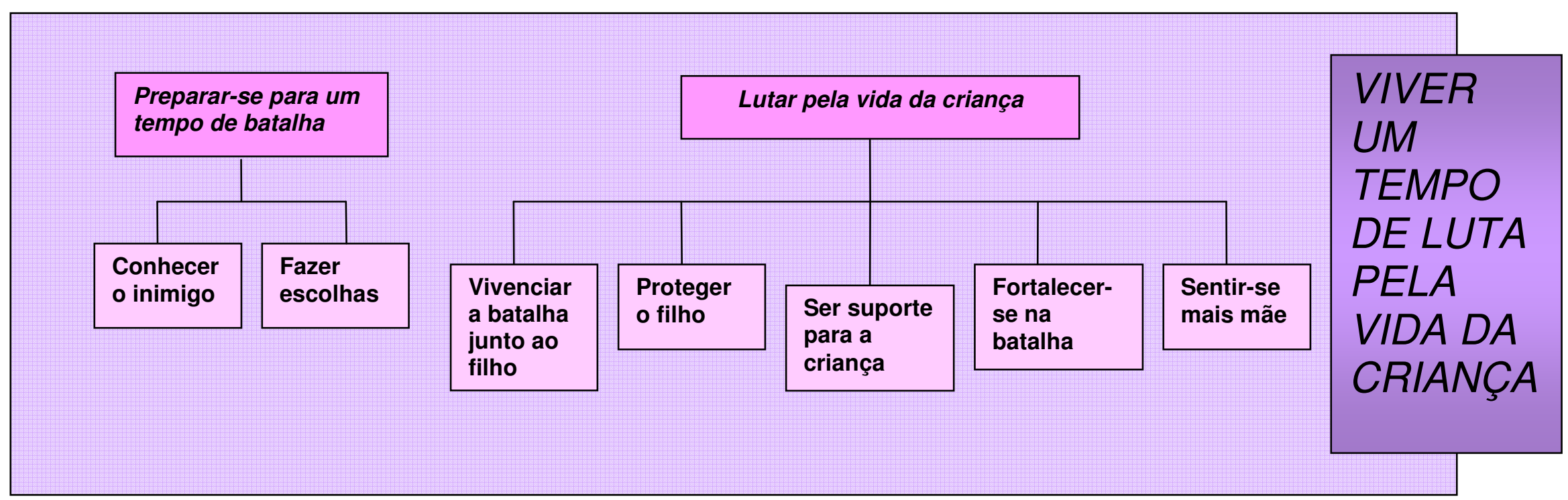

Diagrama 4 - Tema VIVER UM TEMPO DE LUTA PELA VIDA DA CRIANÇA, seus subtemas Preparar-se para um tempo de batalha e Lutar pela vida da criança e as categorias que os compõe. 


\section{Preparar-se para um tempo de batalha}

Preparar-se para um tempo de batalha é o subtema que revela como a mãe se prepara para o tempo difícil que enfrentará ao lutar contra a doença. É um tempo em que obstáculos estão presentes, mas que ela busca elementos que considera importantes para assumir a luta junto ao filho com câncer. É o tempo de conhecer a doença do filho, sua inimiga na batalha, tendo mais armas para lutar; é o tempo de fazer escolhas e tomar decisões mediante as circunstâncias em que ela e sua família se encontram em decorrência do câncer do filho. É quando a mãe estabelece junto a sua família uma prioridade: a vida da criança. A partir daí, todo esforço, dedicação e reorganização da mãe e da família tem como foco o filho doente. Para isso, muitas vezes, é preciso ausentar-se do convívio familiar para acompanhar a criança no lugar seguro escolhido para o tratamento.

Preparar-se para um tempo de batalha é composto por duas categorias: Conhecer o inimigo e Fazer escolhas. Fazer escolhas é uma categoria composta por quatro subcategorias: Decidir que a criança é prioridade, Reorganizar-se tendo a criança como prioridade, Precisar ausentar-se da família e Escolher um lugar seguro. O subtema, as categorias e subcategorias que o compõe estão representadas no diagrama 5. 


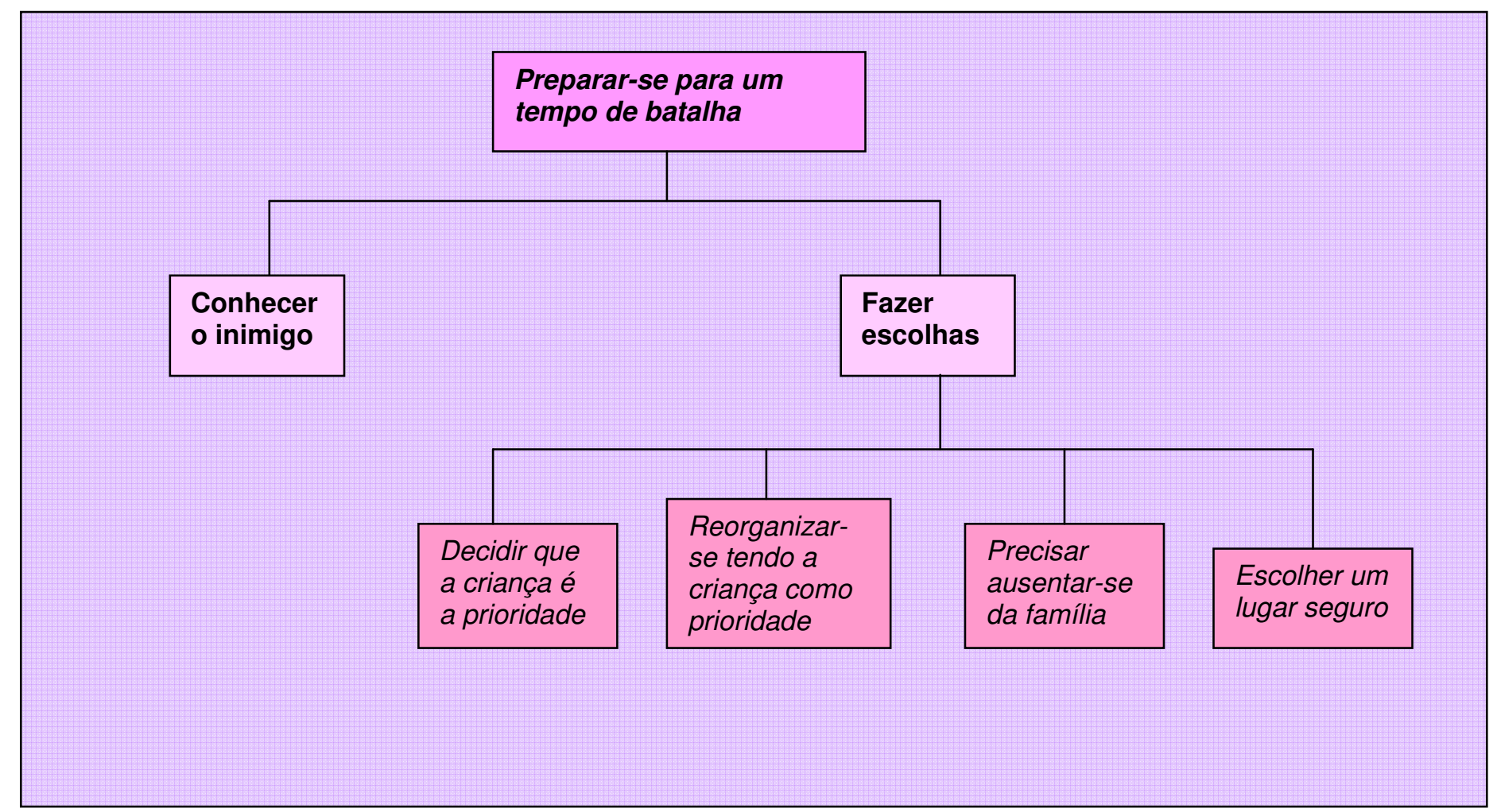

Diagrama 5: Subtema Preparar-se para um tempo de batalha, categorias e subcategorias que o compõe. 


\section{Conhecer o inimigo}

Com o objetivo de se preparar para um tempo de batalha, a mãe percebe que é fundamental saber quem será o seu adversário na luta. Esta categoria revela a busca da mãe em compreender a doença da sua criança, contra a qual ela se prepara para a combater junto ao filho. É buscar informações sobre o câncer através da leitura e conversando com os profissionais da equipe envolvidos na assistência. Este conhecimento the fortalece e proporciona segurança para prosseguir como mãe junto ao filho. Neste tempo de batalha, a mãe busca conhecer realmente quem é o inimigo, o qual ela tem consciência não ser um inimigo qualquer, e sim, uma doença séria. É neste tempo, de conhecer sobre a doença, que a mãe percebe que não está sozinha na batalha e que existem muitas outras crianças e famílias lutando contra o câncer. Esta troca de experiências, que acontece ao conhecer a história de vida e da doença de outras crianças e famílias, faz com que a mãe perceba que a luta é possível, e alimenta a sua esperança neste tempo de lutar pela vida da criança. Ela sabe que cada criança tem a sua luta, por caminhos e em condições muitas vezes diferentes do seu filho. Perceber que não é a única, algo que ela tinha a sensação até então, é algo que a faz unir forças para seguir.

Mas até aí, quando o resultado saiu, que eu fui saber foi aqui mesmo o que ela tinha. Mas eu não fiquei desesperada não! A hora que a médica falou que o rabdomiossarcoma era um tumor maligno. Eu não fiquei desesperada não. Eu só olhei pra ela e falei assim: "É um tumor maligno?" Ela falou: "É, o rabdomiossarcoma é um tumor maligno, mas é de bom resultado, o tratamento tem um bom resultado, tal, tal"... E, fui seguindo, aí aqui que fui conversando com uma mãe, conversando com outra, aí que eu fui ficar mais tranqüila, porque eu vi que o caso da minha filha, graças a Deus, não era tão... Que aqui tinha coisa pior... Que o caso dela... Que graças a Deus ela não sente nada, nessa região aqui. Eu só vi mesmo porque ele enraizou pra fora, graças a Deus que ele enraizou pra fora, porque se tivesse enraizado pra dentro, eu ia descobrir já tinha tomado conta dela, porque ela não sentia nada! (Mãe 1) 
Só o tempo, você vai passando a conhecer melhor, vendo outros casos, os médicos vão conversando com você, como é o caso daqui, você passa a acreditar, e com a evolução também. Você começa a ler muito, que foi o que eu fiz, sobre o problema. Começa a assistir televisão, por exemplo, que sai muita coisa, muita notícia, que surgiu um remédio novo, então você passa a acreditar mais, e se sentir mais forte pra continuar. (Mãe 2)

Depois quando você, como que eu falo, assim... Debate, você vê outras crianças, quando eu entrei no G. e vi outras crianças iguais a ele... Quer dizer, ele ainda não tinha ficado aquele jeito mas ia ficar, né? Então, aquilo, eu falei: "Não, aqui eu vou ter que buscar, aqui eu vou ter que ser forte, né? E aqui eu vou ter que sentir meus pés no chão novamente, eu tenho que sentir que eu não posso fugir da realidade, que eu tenho que assumir isso que está acontecendo e eu tenho que encarar de frente mesmo para eu conseguir passar alguma coisa pro meu filho, né?"(Mãe 3)

Claro que uma criança é diferente da outra, a reação, como vai reagir a uma quimio, a cada processo, cada um reage de um jeito. Mas eu procurei me agarrar, me fortaleceu isso em saber que outras crianças tinham o mesmo grau do meu filho, passavam por tudo aquilo,

outras não passavam, quando tinha que fazer o líquor, tinha que sedar, tinha umas dormiam, outras não, que era o caso do meu, que era difícil dormir, então assim, eu busquei trocar experiências. (Mãe 3)

No começo, no primeiro hospital, assustaram a gente um pouco. Disseram para mim e para o meu esposo que queriam conversar com nós dois juntos, pois as mudanças seriam radicais. Aí falaram do cabelo, das infecções, mas não falaram que cada pessoa responde de um jeito, que cada pessoa é uma pessoa. Aí achamos que ela ia passar por tudo isso. Aí, aqui que falaram, quando ela começou a quimio, que cada um é de um jeito. (Mãe 4)

Entramos aqui, cheguei assustada, cheguei lá embaixo assustada, eu olhava assim, eu imaginava... Até então, eu sabia que tinha essa doença, mas parece que não tem em criança, porque no lugar onde eu moro é só ela. De criança só, de vez em quando aparece algum adulto assim, mas quando eu cheguei aqui e que eu vi tanta criança na mesma situação, tanta criança, eu não sabia.

Aí eu fiquei meio assustada e falei: "Nossa, não é só eu, que estou nessa batalha, tem muita gente que nem eu". Então a gente vai se conhecendo, tem a primeira conversa com a médica, que vai cuidar dela, todas as coisas que falam, dos riscos que têm, e dos que não tem também, das chances que têm também. Aí é o que vai dando mais uma força pra gente também, aqui aí tem os voluntários que ajuda a erguer o nosso ânimo, e dar mais esperança também. (Mãe 6) 
Aí a gente foi se adaptando porquê? Porque a gente tem que se adaptar, juntos, dando força pra ela. É pequenininha, tudo bem, mas já entende, está entendendo o que é uma agulhada, essas coisas. Não sabe porque que é que está aqui, não conhece nem o problema dela, mas eu já sei. (Mãe 6)

E é assim, eu vejo, eu costumo falar pra ela que também que ela não é a única... Porque quando a gente descobre, parece que a gente é o único, a gente pára assim: "Puxa, com a minha filha? Só eu?" Aí quando a gente chega num hospital que a gente começa a ver, quando chega numa casa de apoio, como é o meu caso a gente passa a ver tanta coisa, tanta coisa até pior, aí a gente pára pra pensar: "Eu não sou a única mesmo, e eu tenho que lutar! Muito!"... (Mãe 7)

\section{Fazer escolhas}

Preparar-se para um tempo de batalha é, além de conhecer contra quem irá lutar, um tempo de fazer determinações e escolhas, que representa a tomada de decisão da mãe mediante as necessidades que a batalha contra o câncer lhe impõe. Assim, é necessário avaliar quais as suas prioridades mediante essas demandas, o que acarreta conseqüências para sua vida e a vida de sua família. A partir do momento que a mãe percebe que pode perder o filho, ela toma uma decisão: a de que a criança é o mais importante. Conseqüentemente, é necessária uma reorganização da mãe e da família redefinindo papéis, abdicando de atividades e também fazer uma nova escolha: a de qual lugar o tratamento da criança será realizado. Esta decisão é ancorada pela segurança que a instituição lhe proporciona e envolve enquanto conseqüência, a necessidade de se ausentar da família.

Viver um tempo de luta pela vida da criança é, além de buscar conhecer o inimigo na luta, um tempo de tomar uma série de decisões mediante as demandas da doença. Quando a mãe se prepara para o tempo de batalha, é necessário definir as prioridades naquele momento. Decidir que a criança é prioridade é quando a vida e a cura da criança passam a ser não somente o que há de mais importante na vida da mãe e da família, mas 
também o foco de atenção, a preocupação maior para todos. Ter a criança curada é o que impulsiona todas as demais decisões necessárias nesta experiência e o que a mãe e a família mais desejam neste momento de suas vidas. Além disso, decidir que a criança é prioridade é também batalhar não somente pela sua cura do filho, mas para que ela tenha uma vida no futuro como todas as outras crianças e que seja feliz, apesar de todas as preocupações presentes na experiência de vivenciar o câncer.

\begin{abstract}
Nesse momento o que é mais importante pra mim é ele! É o J., que está tratando. É o tratamento dele em si, essa é a parte mais importante da nossa vida em relação a tudo! Mas depois disso vem a estrutura, se eu puder manter ele, o pai e o irmão, todo mundo junto, em harmonia, essa é a segunda parte mais importante da minha vida nesse momento! Mas... o mais, mais importante mesmo é o tratamento do meu filho! É a batalha para que ele tenha uma vida no futuro normal, ou o mais normal que a gente possa oferecer. Mas o principal hoje é o tratamento, que graças a Deus está indo bem.(Mãe 2)
\end{abstract}

O que é importante, nessa fase? Ela, né! Ela é o mais importante... Pra família toda é ela... A preocupação ainda é muito grande... Os amigos, me ligam pra saber dela, a minha exchefe, me liga: "Como é que está a sua filha", eu digo, "Ela está ótima!". Eles gostam de ver minha força... Tem uma amiga que diz: "S., acho que se fosse eu, eu não ia agüentar... "eu digo, "la sim, menina, Deus te dá força, pra ti agüentar..." Agüenta, a gente agüenta... Eu digo que Deus prepara a gente pra tudo, né... Então a L. é o centro hoje, de tudo... A preocupação toda é ela...(Mãe 5)

O que é mais importante pra mim? Agora a gente não pensa em outra coisa a não ser a cura dela, né? É, acho que é a coisa mais importante, realmente, tanto pra mim, quanto pra minha família, né? Porque pára tudo, fica todo mundo com o pensamento voltado pra aquilo. Por mais que cada um tenha sua vida, tem seu trabalho, mas eu acho que no momento $o$ que está realmente em foco, é a cura dela, o tratamento dela, tanto pra mim quando pra minha família! Pro meu esposo, sabe... Eu sei que vida continua, a gente tem que trabalhar, cada um tem sua vida, né, mas é geral, todo mundo, todo esse desenho que você fez (genograma), todo mundo pensando no tratamento dela, é mensagem todo dia, por telefone, todo mundo pensando que vai dar certo... Eu acho que é o essencial.(Mãe 7) 
Ao decidir o que é mais importante na sua vida e na vida de sua família neste tempo de lutar pela vida do filho, a mãe precisa Reorganizar-se tendo a criança como prioridade. Isso significa refletir sobre o que é possível e o que não é possível assumir e sobre o que será necessário abdicar para que possa ficar mais próxima e disponível para o filho em tratamento. Reorganizar-se tendo a criança como prioridade revela a reorganização da família e dos papéis que cada membro assume tendo como foco a criança doente. Mediante as demandas da doença e ao decidir que a criança é prioridade, a mãe também precisa, muitas vezes, abdicar de suas atividades, desmarcar compromissos se a criança não estiver bem, mudar de emprego ou abandonar suas atividades, deixar para depois os planos de trabalhar, mudar de cidade para a realização do tratamento. Além disso, a mãe vivencia com sua família algumas privações, como viagens e lazer, e não podem mais fazer tudo que faziam antes. Porém, são decisões sem limites, situações em que ela se dispõe a fazer tudo o que for possível e necessário para recuperar a saúde e lutar pela vida do filho. Ela não se arrepende de suas decisões apesar de toda mudança que geram na dinâmica familiar e nas condições da família, pois o que importa é a criança ficar bem.

Mudou tudo, né? Por que eu tive que sair do serviço, assim, não que eu me arrependa, minha filha está em primeiro lugar! Mas eu tive que sair do serviço, tudo isso, mudou...

(Mãe 1)

Porque eu acho que mais que a mãe tenha sofrido, por mais que a mãe não tem tempo, ela tem sim! É ela querer esse tempo que ela tem pro filho! Eu vejo por mim que eu busquei esse tempo! Eu larguei meu trabalho, eu larguei minha casa, e fui atrás do meu filho, fui atrás da vida do meu filho, que para mim era o mais importante, sempre foi. (Mãe 3)

Eu sempre trabalhei fora, trabalhava numa concessionária. Quem cuidava da A. era a minha mãe, que mora na mesma casa. Depois do diagnóstico e da morte do meu marido, eu deixei o meu trabalho e fui para a loja de materiais de construção que era do meu marido. Eu me virei em 10. Primeiramente, por cuidar da casa, da filha e do tratamento, de todos os exames que ela tem que fazer. Marco tudo. Eu é quem traz ela para o hospital. Em casa, ela fica com a avó. Agora eu não posso mais fazer o que eu fazia antes. Agora a 
QT é mais fraca, mas tem coisa que nem tem mais como fazer, viajar. Sempre carreguei ela junto, então hoje tenho que me privar dessas coisas. (Mãe 4)

Olha, eu não posso nem dizer que (a mudança de cidade e deixar o trabalho) foi difícil, a prioridade é ela. Eu não pensei nem na minha pequena o dia que eu vim pra cá! Eu só pensei nela. (...) Eu poderia estar na casa de apoio, eu não fiquei porque eu não poderia ter um computador na casa de apoio, eu não poderia estar falando com a minha família todo dia, ela não ia ter a liberdade que ela tem em casa, então tem tudo isso, né? É muito bom, mas outro lado, você precisa ter a liberdade, e estou aqui, tranqüila, sabe, porque com uma estrutura dessa... Não estou preocupada com emprego nenhum pouco, estou preocupada com a saúde dela, só me interessa isso... A saúde dela. (Mãe 5)

Mas assim, a mudança foi totalmente radical. Posso trabalhar? Não. Por causa dela. Não posso. Um compromisso, você nunca sabe se ela vai estar bem naquele dia. Marca uma consulta, marquei. "Ah, mas a A. está internada, está tomando antibiótico"... Desmarquei. Ah, tem uma consulta com o outro... "Ai, pode levar ele pra mim, eu não vou poder porque preciso ficar com a A., preciso que levar no médico, tem consulta com ela". Aí vai minha sogra lá, corre com o outro no médico, vai lá. Então, quer dizer, muda de uma hora pra outra, é uma correria assim, preciso dar conta de dois. Um precisa de assistência médica também, graças a Deus é saudável, mas tem outra que, infelizmente, está lutando pra voltar a ser saudável.(Mãe 6)

Em conseqüência da decisão de que a criança é a prioridade e da reorganização da família tendo como foco a manutenção da vida da criança, a mãe, muitas vezes, vive a situação de Precisar ausentar-se da família. Isso ocorre pela necessidade de mudar de cidade para o tratamento, ou mesmo da ausência do lar pelas internações freqüentes e, algumas vezes, longas do filho. Esta é uma das piores vivências da experiência de ser mãe de uma criança com câncer, já que a mãe preocupa-se com a família e gostaria de estar também com os outros filhos que ficam em casa. Freqüentemente, a mãe não tem tempo para se dedicar a eles, que, por sua vez, também sentem essa mudança. Ela, como mãe, assim como o marido e os filhos, também precisa de atenção da família. A mãe busca alternativas, ou seja, falar sempre que possível ao telefone e ver a família aos finais de semana, como uma forma de amenizar as conseqüências da ausência e da 
separação e manter-se próxima daquelas pessoas que também fazem parte da sua vida.

É difícil também por você ter outros filhos, por você deixar o outro filho um pouco só, deixar... é difícil conciliar assim, trazer pro hospital, ficar dias no hospital, às vezes internar, passar três dias sem ver o outro filho, isso também é muito difícil!

Por ele, eu to falando no caso de ser mãe né, por ele e pelos que ficam em casa. No caso é mais um. Equando eu vim pra cá, eu vim só com ele. Fiquei uns dois meses sem o outro. É quase impossível você cuidar de um pensando que o outro está um pouco distante de você. Pra conciliar isso não é fácil! E é nisso que se concentra o pior, é ver o filho sofrer e você não poder ajudar, a não ser procurar estar do lado e a ausência do outro, talvez dos outros, que ficam em casa. É assim que eu vejo ser mãe de paciente com câncer. (Mãe 2)

Primeiro eu tive que sair da minha cidade e deixar meu filho lá. Passei dois meses aqui e era aquela coisa... Chorava praticamente todos os dias, junto com meu filho! A falta, procurava falar, toda vez que eu podia no telefone com ele, isso é muito difícil, tanto pra você quanto pro irmão que está sozinho. Com o tempo eu trouxe pra cá, mas mesmo assim não ficou comigo, ficou com uma irmã, seis meses, ela cuidando dele e eu cuidando do que tava doente. E eu via fim de semana. (Mãe 2)

Estou tranqüila que minha filha está bem lá, eu falo com a minha filha todo dia, eu vejo minha filha pelo computador, eu vejo me marido, converso com ele, a hora que dá ele vem aqui, eu to tranqüila. Minha família está estruturada, não teve, assim, nenhum desfecho por causa da doença dela. Tem muitas famílias que isso destrói, né... Por causa da doença... A minha não, até agora... parece que uniu mais ainda. (Mãe 5)

Ah, é difícil porque você se sente cansada, às vezes você fala assim: "Meu Deus, tanto tempo, eu estou tão cansada...". Às vezes você passa o dia todo aqui, sentada, do jeito que eu estou, deitada aqui com ela, no colo. Aí você chega em casa parece que você andou o dia inteiro, uma falta de ânimo, você olha pro filho, ele "Ah, mãe", isso, isso, isso... "Fiz isso na escola", "Ah, meu filho, tá bom, amanhã a gente conversa direitinho, a mãe não vai pro hospital, a gente conversa direitinho, vamos dormir que a gente conversa amanhã..." Sem ânimo... Totalmente sem ânimo "Ah, mãe, mas me pega no colo", "estou tão cansada", e ele tão grandão pra ficar no colo... Tinha uma hora... Eu sinto que ele sente também, mudou também a vida dele. Porque era tudo em função... Ele foi filho único durante seis anos, aí veio a A., ficamos com ela normal, sem nenhum problema durante, o quê, dez meses, e aí foi o tempo da cirurgia e tratamento. De repente, de uma hora pra outra vira aquela correria, 
às vezes não tem tempo pra ele, tipo assim, de às vezes eu ficar aqui no hospital e passar dias e dias sem ver. Entendeu? (Mãe 6)

A mudança assim, afastar do marido, do pai, isso foi uma mudança que ela realmente sente muito. E eu também porque é triste, né, você querer ficar perto de um ente querido e não tem como. Então, você querer dividir, nem sempre dá pra dividir todos os detalhes, porque por telefone é rapidinho, então não tem como. Então, realmente, essa é uma dificuldade, uma mudança que a gente sente bastante. Ela sempre foi muito apegada ao pai e sente muita falta dele. Eu também sinto. É só nós três, né, então, o trio, saiu uma pontinha daquele triângulo, realmente faz falta. E da família mesmo, né, porque a minha família é muito unida (...) Então nós somos muito unidas, meu pai é muito unido com a gente, mora também junto no mesmo quintal. Então a gente procura entrar sempre em contato, a gente procura ligar sempre, tudo... Porque eles ficam preocupados comigo aqui sozinha e eu preciso realmente da atenção deles, preciso ouvir, ela também, ouvir a voz deles. Então isso foi realmente uma mudança que marcou, uma coisa que ela sente muita falta dos primos, são menores, ela é a mais velha, então ela sente demais a falta deles. Como não tem irmão, trata como se fosse irmão, criado tudo junto, todo dia ali, então essa foi uma mudança radical para ela.(Mãe 7)

Sendo a criança a prioridade da sua vida neste momento de preparação e junto a quem ela irá enfrentar um tempo de batalha contra a doença, a mãe precisa encontrar segurança em uma instituição para a realização do tratamento. Escolher um lugar seguro se inicia com a percepção de que é necessário encontrar um local que ofereça condições e recursos suficientes para o tratamento do filho. Além disso, envolve uma série de decisões, inclusive a decisão de deixar a cidade onde vive com a família para ficar com a criança em um outro lugar que the ofereça essa estrutura e lhe proporcione segurança. A mãe busca se informar através de outras mães que também viveram o câncer do filho e entra em contato com hospitais. Para fazer esta escolha, ela não pensa em outra coisa a não ser a criança; ela se prepara, não se abala e nem se importa com a estrutura que o local oferece para ela, pois o foco da sua decisão é o filho. Ela precisa acreditar na equipe, nos profissionais aos quais ela confiará sua criança. A mãe precisa da segurança de que o hospital e os profissionais responsáveis 
pelo filho estarão batalhando pelo mesmo objetivo que ela durante este tempo de luta.

Aqui, é normal! Não é ruim, vou falar pra você que é ruim. Que nem eu falei, tem gente que reclama do hospital. Reclama das enfermeiras, reclama disso, eu não vou falar porque eu não tenho do que reclamar daqui! É como se eu tivesse em casa, quando ela está internada, quando ela está aqui (no ambulatório), é como se eu tivesse em casa. (Mãe 1)

Porque o N. é muito bom de se morar, mas quando chega um problema de saúde, pelo menos na capital onde eu estou, eu vi que não tinha estrutura pro tratamento dele. Como a maioria das mães que eu converso de lá, quem pode tira e quem não pode se arrisca e é muito difícil! A sobrevivência de um paciente com câncer num lugar sem estrutura além de ser doloroso e difícil pro paciente é doloroso também pra mãe, pra família, no geral. E no meu caso, eu sempre fui muito teimosa em relação a tudo, foi mais difícil porque ninguém acreditava, achavam que eu queria demais pra ele. "Ah, você não tem condições, porque você quer? Porque você quer tirar daqui?". Só que eu sempre fui muito obstinada por eles e se alguém dissesse que tinha tratamento fora do país e eu tivesse condições ou me dessem uma passagem, chegasse a isso, eu ía embora. Por isso eu estou aqui! Então como foi que eu cheguei aqui? Cheguei aqui, eu saí procurando várias mães na minha capital A. que tinham passado por esse tipo de problema e conheci mais ou menos umas cinco e a maioria tinham tirado pra fora e os filhos estavam muito bem. E logo que começamos, um mês depois ele teve um derrame, um derrame cerebral, teve uma hora e meia de convulsão e quando os médicos conseguiram entubar falaram pra mim que tinha sido um derrame, que ele estava... que ele estava em coma, talvez ele não voltasse a andar, falar e só o tempo poderia dizer o que ía acontecer. E a médica do tratamento falava que não tinha nada a ver com o problema e não tinha nada a ver com as quimioterapias. Aí eu liguei para vários hospitais de fora de A., tipo H.C., B., C., eu ligava e eu conversava com alguns médicos que queriam me atender e falavam que as quimioterapias poderiam levar a isso e eu fui conversar com ela e ela falou que não tiraria as quimios, esse tipo de quimio que causava isso, só tiraria se tivesse um choque anafilático. Aí eu vi que não tinha mesmo condições de continuar lá! Falei com ela pra ela me encaminhar e ela disse que não, que lá tinha tratamento e que não ia me encaminhar, e eu vim pra cá sem encaminhamento através de uma mãe de lá que fazia tratamento aqui em S.P., que conhecia o Dr. S.. Foi ele que com muito boa vontade falou pra essa mãe que se não desse pra ficar na clínica dele ele trazia pro G., que ele tinha uma instituição que tratava de crianças com câncer. Foi assim que eu cheguei ao G.. (Mãe 2) 
Outra coisa muito importante que acontece aqui em S.P., é que os médicos, eles não enganam você. Eles são muito sinceros. Eles sempre falam a verdade, como seu filho está, o que é que pode acontecer, eles orientam muito, isso deixa a mãe mais segura. Depois do que eu passei, então, você tem bem mais segurança. Então nessa segunda, nessa recaída do meu filho, eu me senti bem mais segura! E dá até pra conciliar um pouco, dar mais atenção em casa, ao marido, ao filho que ficou, devido a essa segurança.

(Mãe 2)

E eu saí de madrugada, liguei pra doutora, ela falou pra gente estar indo pro hospital mais próximo, a gente foi tudo, mas lá nesse hospital não era assim um hospital que fazia o acompanhamento oncológico, era um hospital normal. E lá a gente pegou uma médica de plantão, e eu lembro que ela ligou pra Dra. S. mas mesmo assim ela quis ela diagnosticar, então ela queria fazer uma lavagem no G. Era uma coisa que não podia ser feita. Sabe então, a insegurança de ter um hospital que faz o tratamento e de repente você ter que ir para outro que não está acompanhando o caso, que não sabe desde o começo o que ele passou, que não tem todo o acompanhamento, então essa foi outra dificuldade que eu tive. De deslocar de um hospital para o outro, como o G. ainda não tem hospital permanente então tive que ir pra lá. Então uma segunda dificuldade que a gente teve, que eu tive, foi essa. (Mãe 3)

Porque eu sei da doença, aí quer dizer, quando eu descobri, eu não pensei duas vezes, eu vir pra S.P., eu sabia que a minha filha menor estava bem, tem a minha mãe, tem as minhas irmãs, tem um monte de gente pra cuidar dela lá (...) Quer dizer, eu só pensei no momento nela, não pensei no meu emprego que eu larguei, não pensei em nada, nada, nada... Minha única idéia era ela. O objetivo era ela, é ir daqui com ela curada, eu acredito que ela já até esteja, não pensei, eu não me preocupei com meu emprego, não pensei mesmo. Tanto é que quando eu vim pra cá, eu soube que tinha casa de apoio. Quando eu vim pra cá, o meu marido tava com medo: "Tu é louca, tu vai assim pra lá, tu não sabe como é a estrutura lá". Eu olhei e disse: "Olha, P., eu posso até ficar sentada lá numa cadeira, a noite inteira do lado da minha filha, mas contanto que eu traga ela curada! Isso pra mim não é problema nenhum!" Quando eu cheguei aqui e eu vi toda essa estrutura, não era nada do que ele estava pensando, tanto é que quando ele veio também, ele viu como a estrutura era boa, tinha casa de apoio se eu quisesse ficar...( Mãe 5)

Foi uma coisa meio que de surpresa, né? Não tínhamos planos, nem condições também...

Então, e eu assim, sem saber realmente se íamos ficar muito tempo, mas nós viemos preparadas. Porque eu conhecia já, sabia de casa de apoio, sabia que tinha possibilidade da gente, se o caso de ela ficar, tinha como, só que eu vim com meu marido, eu e ela. E chegamos aqui, passamos no consultório, não tinha vaga em nenhuma casa de apoio, falei: 
"Ai, meu Deus, e agora?", mas tudo bem. Ficamos dois dias num hotel, a assistente social disse que ia conseguir uma vaga pra gente, conseguiu, nessa que nós estamos até hoje. Foi uma mudança assim, um pouco radical, né? Mas foi uma escolha nossa, que ficar lá e ela ficar sem a perna e a gente ficar aqui por um período mesmo sem saber quanto, eu não me importei, e nem ela. (Mãe 7) 


\section{Lutar pela vida da criança}

Na experiência de ser mãe de uma criança com câncer, viver a luta pela vida do filho é viver junto a ela todos os momentos da batalha contra a doença, estando próxima e disponível em todos os momentos desta jornada. É também proteger o filho de qualquer acontecimento eventual que possa colocar sua vida em risco, tendo um cuidado especial com ele, um cuidado maior do que o que ela já tinha como mãe, observando mínimos detalhes que antes talvez ela não distinguiria como importante. É permitir que a criança viva seu tempo de criança, ao mesmo tempo em que é também colocar limites dentre as atividades que a criança quer realizar, em decorrência das peculiaridades da doença. Ao lutar pela vida da criança, a mãe é o seu suporte. Isso inclui preparar a criança para a batalha, transmitindo força e segurança, para que a criança também possa confiar que tudo vai dar certo. Ser suporte é também revelar para ela a doença contra a qual estão lutando, falando sobre a doença da maneira certa e na hora certa. Por fim, para ser suporte é necessário contar com a ajuda da criança, esperando que ela colabore com a equipe e consigo mesma. Lutar pela vida da criança representa também a busca da mãe em se fortalecer para viver essa batalha junto dela, já que a luta é de ambos e nenhum dos dois pode desanimar. Fortalecer-se envolve assumir aquela luta como se fosse dela e vivenciar a necessidade de cuidar de si mesma e da família, da qual ela faz parte. Tudo isso faz com que a mãe se sinta mais mãe da criança, pois agora, ao viver o tempo de lutar pela vida da criança, ela percebe-se fazendo mais do que fazia antes e mais do que achava que seria possível. Ela percebe-se vivendo plenamente aquela experiência em uma relação de amor ainda maior do que sentia antes da doença.

Lutar pela vida da criança é um subtema composto por cinco categorias: Vivenciar a batalha junto ao filho, Proteger o filho, Ser suporte para a criança, Fortalecer-se na batalha e Sentir-se mais mãe. São compostas por subcategorias e estão representadas no diagrama 6. 


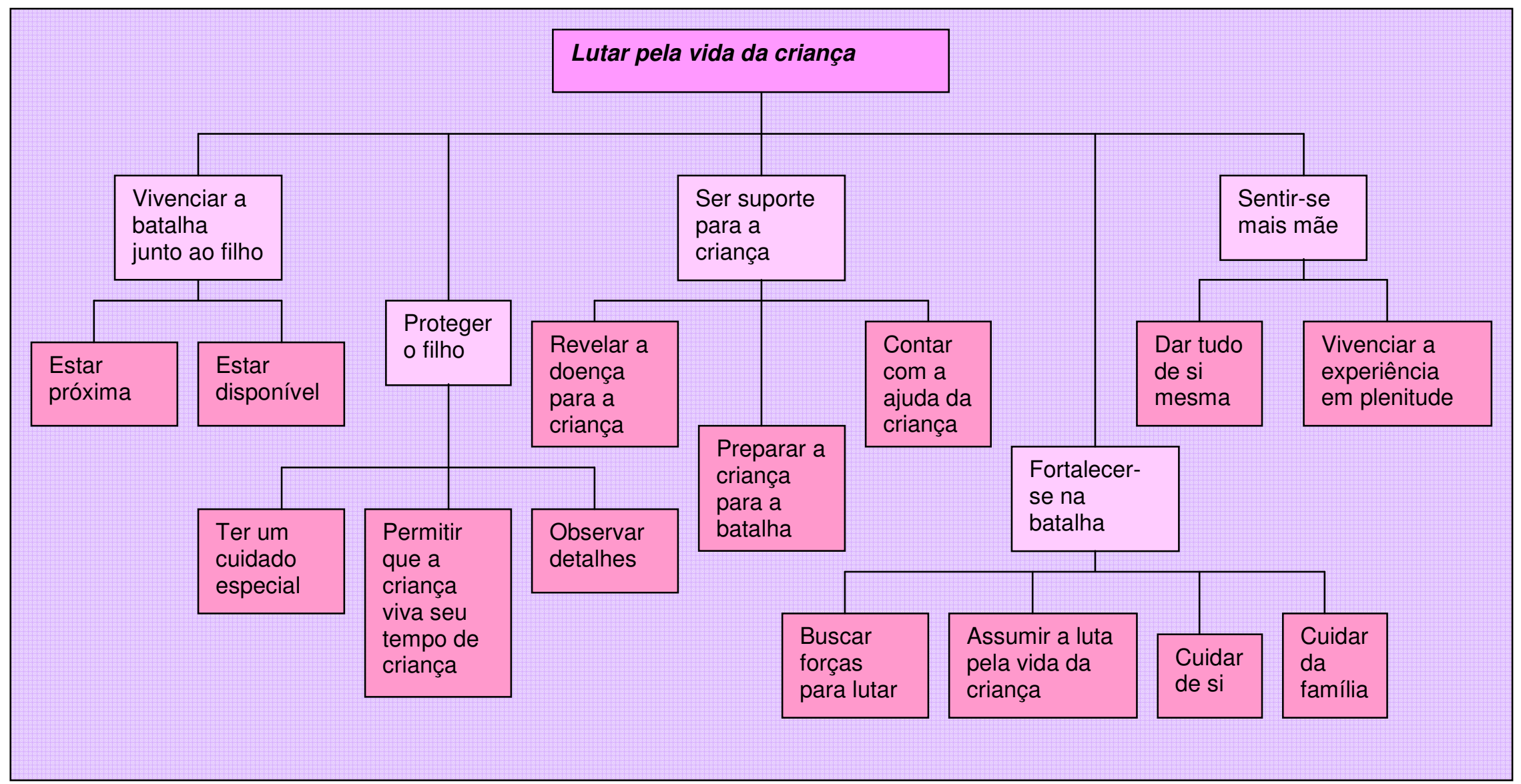

Diagrama 6: Subtema Lutar pela vida da criança, categorias e subcategorias que o compõe. 


\section{Vivenciar a batalha junto ao filho}

Ao vivenciar a experiência de ser mãe de uma criança com câncer vivendo um tempo de lutar pela vida do filho ameaçada pela doença, a mãe busca acompanhá-lo em todos os momentos da experiência da doença. Esta não é uma tarefa fácil. Estar próximo e disponível a todo tempo ao filho doente significa, muitas vezes, ficar longe dos outros filhos, da sua casa, da convivência familiar. Além disso, a disponibilidade é algo que ela precisa buscar, abdicando de determinados compromissos como mãe e como membro da família, do trabalho e outras atividades que a impedem de estar junto à criança. A mãe, ao vivenciar a batalha junto ao filho, torna-se mãe em tempo integral, sem descanso, e passa a viver em função da criança que está doente. Desta forma, estar disponível permite que mãe e filho permaneçam mais próximos, sendo a disponibilidade e a proximidade condições que acontecem de forma integrada ao vivenciarem esta batalha contra o câncer.

Durante toda a trajetória da doença, a mãe procura Estar próxima ao filho, estabelecendo esta relação de proximidade durante todos os momentos, inclusive os de internação. É estar junto durante um procedimento, sempre se mostrando forte e reconhecendo as necessidades da criança somente ao olhá-la. Esta relação de proximidade que a mãe estabelece com a criança se fundamenta na percepção de que a doença é séria e os procedimentos aos quais a criança é submetida the causam desconforto e sofrimento, sendo necessário assim que ela permaneça ao lado do filho. Lutar pela vida da criança permanecendo próxima a ela faz com que a mãe se sinta privada de fazer algo pelo filho quando, em determinada situação ou procedimento, ela não pode permanecer junto dele. Não saber o que está acontecendo é algo difícil, pois apesar da confiança que tem nos profissionais, sabe que quem melhor conhece sua criança é ela. Além disso, estar próxima na luta pela vida da criança permite ampará-la em uma situação difícil. Desta forma, a mãe deseja estar junto ao filho, 
poder tocá-la e não quer sair do lado da criança, presenciando todas as situações que ela vivencia. A mãe entrega-se à criança, nunca a abandona e sente-se, então, mais próxima dela do que anteriormente à doença.

Ainda meu marido teve que sair, saiu chorando, meu marido é enorme! Ele é enorme, mas só tem tamanho! Só tem tamanho ele não agüenta, ele não segura pra dar injeção, não segura pra tirar sangue, então minha filha era tudo eu! Tudo eu.(Mãe 1)

Então, como mãe eu vejo assim, que foi uma experiência muito... Vamos dizer, até que boa em partes, de tudo isso eu vejo que pode tirar alguma qualidade, porque aí sim que está o prestar do seu filho, porque como mãe a gente sempre está ao lado do filho, mas nessa hora você está mais, você duplica, porque você acaba vendo o outro lado da criança que você ama, que você gerou, que você mais que você tem que dar uma atenção maior ainda por ser um caso especial, por você saber que está tratando de uma doença que é séria, não é uma doença qualquer. (Mãe 3)

Olha, o primeiro momento foi o momento quando meu filho entrou para uma sala de cirurgia, que foi pra colocar o cateter. Até ai ele nunca tinha passado por cirurgia nenhuma, então foi um momento difícil, assim... Porque a gente chegou no hospital e ele teve que entrar pra ir pro centro cirúrgico e não podia mais o acompanhamento do pai, mãe, e foi aonde eu me

senti bem enfraquecida de não poder estar junto com ele ao entrar dentro do centro cirúrgico. Ele entrou nos braços da psicóloga, da E. e eu tive que ficar dali daquela porta pra trás. Então pra mim foi uma dor muito grande que eu senti no coração. Apesar de eu estar confiante que tudo fosse dar certo, que eu estaria entregando ele nas mãos de pessoas capacitadas, pessoas formadas, mas eu me senti assim, como vou dizer... Incapaz, não sei se é a palavra certa, de estar junto, eu queria estar junto do meu filho! Foi uma separação, não sei se é esse termo que eu posso dizer, de acho que foi duas horas, mas que parecia que foi uma década! Foi muito tempo longe, eu queria saber o que estava acontecendo. Sabe, foi uma angústia, foi um aperto que eu nunca tinha sentido na minha vida. Então essa foi uma das dificuldades que eu passei, a primeira delas. (Mãe 3)

(...) Eu acho que como toda mãe a gente quer ver, a gente quer sentir, a gente tocar, presenciar o que a criança está passando! Não que falte a confiança nos médicos, na enfermagem, não é isso. É que como mãe a gente sabe, num olhar a gente reconhece seu filho, numa expressão do rosto a gente está conhecendo o que a criança está querendo dizer ou não. Então, pra mim, eu fazia questão de acompanhar tudo, eu nunca quis sair do lado dele, porque pra mim, eu queria ver no rosto dele, eu queria sentir também o que ele 
sentia, que queria de qualquer forma estar ali com a mão estendida, pra ele poder entender, confiar em mim, como mãe. E foi sempre assim eu acho que dá muito certo você abandonar mesmo, você se entregar pro seu filho de corpo, de alma, de coração, porque vale a pena. Você tem que estar sempre firme do lado dele, mostrando que você vai vencer junto com ele, né? (Mãe 3)

Além disso, a mãe procura Estar disponível, que significa concentrarse totalmente no tratamento da criança, dedicando-se integralmente ao filho doente e não ter tempo de pensar em outras coisas. Ela percebe que trabalhar fora ou desenvolver determinada atividade que seja necessário ficar longe da criança não é o mais importante, mas sim poder agir para suprir as suas necessidades em todos os momentos que ela precisar. Ela não relaxa em momento nenhum e deixa todo o restante de lado, já que existe uma ameaça à vida do filho. Assim não é permitido vacilar. Vivenciar a batalha junto ao filho com câncer é estar ao seu lado o tempo todo porque existe um medo muito grande de que algo ruim Ihe aconteça. Assim, é estar pronta para agir imediatamente, impedindo que algo dê errado, vivendo um estado de alerta e vigilância sem pausa, sem descanso. Ao estar disponível vivenciando um tempo de luta pela vida da criança ela busca ser paciente prestativa e ajudá-lo cada vez mais, dispensando toda atenção de que a criança necessita e passando o tempo todo ao lado dela. Ela fica hospitalizada junto ao filho, passa dias na instituição, sem voltar para a casa, e se sente mais atenciosa e dedicada com a criança.

Como eu falei, no começo a gente se concentra praticamente vinte e quatro horas no tratamento. O medo de alguma coisa dar errado é enorme! A gente se sente insegura, porque tudo é novo, né, você busca informação, mas tudo é novo e existe aquela coisa de você ter o diagnóstico e você ainda não acreditar muito... É futuro muito incerto na verdade! O medo sempre aparece, mas... Com o tempo é que você vai perceber o quanto você viveu esse período mais pra o que tava doente, deixando o restante de lado... (Mãe 2)

Não, no começo a gente não se dá conta, porque a gente se concentra totalmente no tratamento e porque você não tem muito tempo pra pensar em outras coisas. 
Eu pelo menos fiquei praticamente vinte e quatro horas praticamente vivendo pro J.. Eu quase me instalei no quarto dele, eu sou esse tipo de mãe exagerada... (Mãe 2)

Eu acho que o amor prevalece tudo, né? O amor ele é assim, de uma forma mãe pra filho, indiscutível. Eu acho que toda mãe deve amar seu filho, com problema ou não... Ela tem que ser a mãe que eu acho que em todas as horas ele deve contar, não só nas horas alegres, mas nas horas difíceis também, porque não? Eu acho que até aí tem que, como eu falei, bato muito nessa tecla, tem que doar muito mais do que a gente pode. Eu acho que o amor acima de tudo fortalece, ele é a base. Pra tudo que vai acontecer com a criança, o amor é a base de tudo. Se não tiver essa base com amor, não vale tudo aquilo que você faz. Mesmo você sabendo, mesmo você tenha, acho que certeza, que talvez seu filho pode não ser curado, ou há, que surge essa dúvida de um dia não ter a cura, eu acho que se você fizer com amor e você dedicar, todo segundo que você passar ao lado dele, eu acho que tudo se transforma. Tudo muda, tudo pode, tudo fortalece, acho que tudo crê quando você tem amor. (Mãe 3)

Então essa mãe $S$. depois do tratamento é uma mãe que eu acho que todas as mães são, mas que a gente tem que descobrir, tem que ir lá no fundo buscar essa mãe que existe dentro da gente. Porque eu acho que mais que a mãe tenha sofrido, por mais que a mãe não tem tempo, ela tem sim! É ela querer esse tempo que ela tem pro filho! Eu vejo por mim que eu busquei esse tempo! Eu larguei meu trabalho, eu larguei minha casa, e fui atrás do meu filho, fui atrás da vida do meu filho, que para mim era o mais importante, sempre foi. Então eu acho que é esse redescobrir que você pode, você consegue, se você realmente ama seu filho, você vai correr atrás, você vai procurar fazer de tudo de bom pra ele.

(Mãe 3)

Aí estou aqui, mas eu sempre fui muito dedicada pras minhas filhas, eu amo todas duas, sabe... Eu sempre me dediquei muito a elas, por mãe mesmo, eu que cuido, eu que dou banho, por mais que eu tenho uma pessoa que trabalhe pra mim, eu que gosto de dar banho, eu que gosto de arrumar, pentear o cabelo delas, sabe? Nunca deixei na mão de empregada, eu que gosto de cuidar! Eu sempre tive dentro de mim que, trabalhando, mas que quem cuidava delas era eu! Eu sou uma mãe assim. E até hoje... Essa aqui, eu digo assim: "Ai, meu Deus!!" Tudo que ela pede eu faço, tudo eu faço, sabe! Eu digo pra ela: "Não tem mais o que fazer pra ti, porque tu reclama, eu não sei mais o que fazer". Eu sou mãe assim. Não relaxa, nenhum momento... (Mãe 5)

Porque, assim, é difícil? É... por um lado eu já tenho outro filho, eu já cheguei a ficar aqui 11 dias direto no hospital, sem ir pra casa, com ela internada, com esse negócio de defesa baixa. Na primeira vez que baixou a defesa dela, ela teve uma bronquite, ficou 11 dias 
tomando antibiótico. Aí o outro fica em casa, você fica, assim, meio atordoada porque você tem o outro lá. (Mãe 6)

Realmente foi, foi um momento que eu acho até que eu me aproximei mais da T.... Porque quando a criança está normal, a gente até dá carinho, a gente conversa, a gente sempre foi muito amiga, mas quando está passando por uma situação assim, eu acho que a gente se aproxima mais... Ainda mais eu, estando aqui, meu tempo total é pra ela! Não tem nem marido, não tem mais ninguém pra dividir, o tempo é só pra ela! Então foi uma mudança muito radical, eu, mas eu não vou dizer assim que eu sinto... Eu sofro, claro, mas eu estou aqui com ela pra o que der o vier, não vou ficar também: "Ah, estou sofrendo, ah... ". Não, eu estou junto com ela, ela sabe disso mais do que tudo, sabe? (Mãe 7)

\section{Proteger o filho}

Vivenciar a luta pela vida da criança é buscar a todo o momento protegê-la das ameaças que a doença ocasiona. Proteção é algo que sempre fez parte do seu papel de mãe, mas agora, neste tempo de lutar contra o câncer, significa ter um cuidado maior do que o cuidado que sempre teve como mãe. É uma estratégia da mãe ao fazer o seu papel a fim de afastar a criança da ameaça representada pela doença. Ao proteger sua criança, a mãe busca cuidar da escola e do tratamento, das consultas e dos exames, e também mostrar os limites impostos pela nova situação difícil que estão vivendo. Ao mesmo tempo, é proteger a história do filho, permitindo que ele viva a sua infância em plenitude e que ele possa viver esta fase da vida como seus outros filhos, como qualquer outra criança. Proteger significa também observar todos os detalhes que antes da doença, talvez, passariam despercebidos e agir de forma a considerá-los como importantes. A mãe, ao viver a luta pela vida da criança, quer proteger o filho acima de qualquer coisa, tendo como propósito não permitir que nada de ruim Ihe aconteça.

Para proteger o filho, a mãe passa a ter um cuidado dobrado e minucioso. Ter um cuidado especial é ter um cuidado que é maior do que o cuidado que ela tinha antes da doença. É protegê-lo de complicações do 
tratamento mediante a sua vulnerabilidade e fragilidade, ocasionadas pelo câncer e o tratamento oncológico. Assim, ela tem um cuidado dobrado com a sua alimentação, higiene e busca proteger o filho de infecções. Ela se preocupa com o que pode ser feito e com o que não pode, visando ajudar para que a criança melhore. Preocupa-se também quando, apesar de todo cuidado especial, a criança apresenta algum agravo, como uma febre. Ter um cuidado especial ao lutar pela vida da criança é também protegê-la da doença cuidando do seu tratamento, marcando consultas e exames, cumprindo as orientações conforme as especificidades daquele momento. É, além disso, impor limites para a criança, de acordo com as restrições do tratamento. Para a mãe, este cuidado especial é necessário, seu desejo e propósito para proteger o filho são ainda maiores a fim de que nada de ruim aconteça a ele, afastando-o da ameaça que a doença representa.

Eu tive que ter um cuidado mais especial com ela, né? Que nem explicam aqui as nutricionistas, coisa de comida dela... Apesar de que graças a Deus, eu sempre fui, não é me gabando, eu fui sempre limpinha com ela, né? Mas eu tive que dobrar mais o cuidado com ela, entendeu? Criança, você sabe, qualquer porcaria quer pôr na boca. O único cuidado é isso, alimentação dela, porque ela é horrível pra comer... Desde antes de saber disso ela já era chatinha pra comer...E mudou só isso... que eu saí do serviço, e o cuidado com ela é mais dobrado... (Mãe 1)

É normal pra mim. Eu já tinha cuidado com ela antes, entendeu? Então assim, não vou dizer que sou um exemplo de mãe, tal, tal... Mas eu sempre tive cuidado, graças a Deus, com meus filhos, entendeu? Então pra mim, não teve muita diferença assim, como mãe, de uma criança com ou sem. Porque eu tenho ela com, e o outro sem... Então, não tem muita diferença, a única diferença que eu falo é que o dela, o probleminha dela eu tenho que ter mais cuidado... O probleminha dela tem que ter mais cuidado, assim, com alimentação, com essas coisas, defesa baixa, bactéria, essas coisas, bicho, lá em casa não tem bicho! Nenhum! Só tem dois passarinhos, do meu marido, só... só essas coisas... Mas pra mim, como mãe é comum, normal! (Mãe 1)

É assim que eu me vejo, eu me sinto mais mãe agora, eu sinto mais vontade de proteger, sabe, de... Se cada picada pudesse dar em mim, se eu pudesse estar no lugar dela... Mas 
infelizmente, né? Tem que ser... Tem que ser ela que tem que passar... E eu também, né? Eu como mãe e ela como filha... É desse jeito que eu me vejo... (Mãe 6)

A minha vida de mãe? Eu sempre fui bem dedicada a ela, porque eu parei de trabalhar pra ficar com ela, logo quando ela nasceu. Então eu fiquei, a vida dela toda, em casa. Mas agora, depois que começou o tratamento, realmente, foi uma mudança. Antes a gente ia no médico uma vez ou outra, era uma coisa bem mais tranqüila, não tinha tanta preocupação com cuidados especiais, porque criança tem cuidado, mas não é aquela coisa que nem agora... (Mãe 7)

Proteger o filho é também proteger a sua integridade enquanto pessoa, ou seja, é Permitir que a criança viva o seu tempo de criança. É permitir que ela continue escrevendo a sua história apesar de estar vivenciando um tempo de luta. Ela procura não fazer diferença ao cuidar dos filhos, permitindo que a criança possa brincar, e tenta educá-la como fazia antes da doença. A fim de protegê-la da exclusão do convívio social e com outras crianças, a mãe tenta transmitir para o filho a idéia de que a doença é uma fase na sua vida e que não vai impedir que ele continue sendo criança; que os efeitos do tratamento na sua aparência não mudam quem ele é enquanto pessoa. Ou seja, permitir que a criança viva seu tempo de criança significa também ajudá-la a compreender, aceitar e conviver com as mudanças e restrições que a doença lhe impõe, nunca deixando de proteger e supervisionar em suas atividades. Permitir que a criança continue vivendo seu tempo de criança apesar da luta vivenciada dia-a-dia contra a doença é ser a sua barreira se ela precisar se esconder, mas é também permitir que ela continue interagindo com outras crianças e com o universo do ser criança, proporcionando-lhe a certeza de que continua fazendo parte dele.

A minha mãe fica morrendo de cuidado com ela, pra ela não cair, meu marido, mas ela não pára! A perna é tudo roxa, pra você ter uma idéia, ela ter uma idéia (mostra as pernas da filha, que está no seu colo), tanto é que eu perguntei... ó... Que ela não pára um minuto, braço, cotovelo, é tudo assim, machucado, que ela não pára um minuto...E meu marido, ficam tudo secando, quando minha mãe está em casa, fica tudo que nem galinha secando 
ela. Eu não! Eu deixo brincar, deixa ela correr... Eu deixo ela brincar a vontade, eles não, ficam secando ela. Ela não gosta, sabe que fica em cima. (Mãe 1)

Eu trato ela normal. Eu trato ela como uma criança normal. Que nem eu falei pra C. a enfermeira, a enfermeira falou: "Não, você está certa mesmo"... Eu falei, eu não trato minha filha como doente, ela não é doente! Se precisar apanhar ela apanha! Se ela tiver aprontando e precisar tomar umas chineladas, ela toma! Entendeu? Porque isso aqui é triste, minha filha, se você deixar ela te faz de gato e sapato... Entendeu? Só a idade dela que é pouca, mas a mentalidade dela, ó (faz sinal de grande com a mão)... desse tamanho... Pergunta pras enfermeiras o que elas te falam! Então eu trato ela normal... Entendeu... Não trato ela assim, como... Meu marido não, meu marido, mas estraga, se eu dou um tapa nela ele briga, ele não gosta que bata nela. A minha mãe, a mesma coisa, tem uma irmã minha que misericórdia! A G., mais velha, se vê, ela já chama ela... De tanto que ela protege ela, se eu vou dar um tapa minha irmã toma frente, pega ela e sai correndo, é assim. Mas eu trato ela normal, se precisar bate, bato, não espanco! Mas se precisar levar uma chinelada, ela toma, se precisar tomar uma bronca, ela toma! Como outra criança normal, trato ela normal... (Mãe 1)

O G. se sentia rejeitado, porque quando caiu cabelinho, começou as fases assim, então ele não queria ver amiguinho dele, em casa, visitando, ele queria ficar sozinho... Então passa essa parte de experiência de você ensinar que não, que não é por causa da leucemia, por causa do câncer, que ele vai se sentir excluído, entendeu? Então esse lado de mãe que eu vi, assim, de poder passar isso pro meu filho. Uma doença não ia atingir as outras áreas de ser criança, que ele não ia deixar de ser criança por causa daquilo, porque o amiguinho ia achar que ele estava careca e ia dar risada, ou fazer alguma coisa. Não! Você entendeu?

(Mãe 3)

Até que chegou um dia, que partiu dela e ela disse assim, que não queria mais, que queria raspar a cabeça, porque ela não agüentava mais cabelo no corpo dela... Aí eu peguei ela num sábado, disse: “Você quer mesmo raspar?”, ela disse: “Quero", peguei ela, levei no cabeleireiro, raspou... Foi um choque, você ver... pra mim foi horrível, sabe? Aí peguei, raspei... Quando foi a tarde ela disse: "Mãe, vamos ao shopping?" Ela tinha um boné. Peguei, botei o boné nela, e fomos pro shopping. Chegou no shopping, eu percebi a L. se escondendo atrás de mim, sabe, o tempo inteiro, a barreira, eu era a barreira dela. Mas eu fiz que não percebi. Ela pegou, olhou pra mim e disse, nós nem demoramos, lá no I. "Vamos embora pra casa?" "Você já quer ir embora L., nós acabamos de chegar!" "Eu já quero ir embora...", "Porque você quer ir embora?" "Porque está todo mundo me olhando..." Eu disse, "Olha, deixa eu Ihe falar: se você que visse uma criança careca, você não ia olhar?", ela disse: "Eu ia", "Pois é, você é diferente pra eles! São crianças, minha filha, nem sabem 
o que está acontecendo... Quando olharem pra você, você dá um sorriso, que aí eles vão ver que você está bem, e não vão mais olhar pra você". Aí, passou. Nós íamos saindo do shopping e ia entrando uma criança, paraplégica, na cadeira rodas, só mexia os olhos, eu disse: "Olha, só essa criança, com certeza ela está feliz da vida por estar passeando no shopping. Ela não mexe as os braços, pernas, só está mexendo os olhos, você está vendo?" Ela disse, "Estou", "Pois é, você só não tem cabelo, e cabelo não faz falta... Cabelo não te muda em nada, só vai mudar tua aparência, só isso... O teu eu, de dentro, não vai mudar nada, você é você mesmo, acabou..." Desde aí, ela sai comigo hoje, ela tira o chapéu no meio da rua, se eu tiver no shopping, ela tira o chapéu, fica carequinha, ela não liga pra nada, ela vai pro aniversário com a amiguinha dela, as crianças chegam, perguntam pra ela, ela diz: "É porque eu faço um tratamento que cai o cabelo", fala assim... Super natural... (Mãe 5)

A mãe não somente tem um cuidado especial com a criança, com sua alimentação e higiene, e permite que ela viva seu tempo de criança apesar das restrições do tratamento, mas também procura estar atenta a tudo que acontece com ela. Ou seja, a mãe passa Observar detalhes, mesmo que mínimos, e que antes da doença provavelmente passariam despercebidos. São detalhes que ela não somente observa, mas também os valoriza porque sabe que podem ter um significado importante. Por exemplo, a atenção às reações da criança quando está recebendo quimioterapia, as mudanças que acontecem no seu corpo que podem indicar alguma resposta à determinada terapia. Tudo isso a mãe observa a fim de proteger a criança de qualquer complicação ou agravo a sua vida.

Voltamos pra S.P no dia 2 de janeiro, pra continuar o tratamento, só eu e ela. Quando a L. chegou em S. P., piorou. Começou a ter febre de novo, a hemoglobina abaixou muito... Aí dia 11 de janeiro a L. internou, porque tava com a defesa baixa, hemoglobina baixa, tava tudo baixo, internou. Aí ficou no antibiótico, e nisso o Dr. F., que é o médico dela tava viajando. E tava esperando ele chegar, pra tomar uma decisão, pra ver o que ele ia fazer com a L.. Quando foi no dia 17 de janeiro ele chegou. Passaram pra ele o caso dela, porque ela tava tomando sangue um dia sim, um dia não, e a hemoglobina não subia. E cada vez que ela tomava sangue eu percebia que a barriga dela tava desenvolvendo. Aí a médica 
percebeu isso, que tava desenvolvendo, aí quando o Dr. F. chegou, ele resolveu: "Vamos operar". (Mãe 5)

Aí vem aquela coisa, porque assim, a gente pensa assim, que vai ser o quê, um dia só de quimioterapia e daqui a 21 dias, vem e não tem. Aí depois vem aquela coisa de ciclo, são três dias direto, com hidratação, aí falei: "Nossa, ela vai ficar muito ruim!" Um medo, na primeira quimio eu fiquei apreensiva, olhando pra ver o que ela ia sentir, se ela ia ficar mal, se ela ia ficar isso, aí não sentiu nada, até hoje, ela faz as quimios normal. O problema dela é a defesa, que abaixa muito a imunidade, aí tem que ficar internada. (Mãe 6)

Você vê a vida de uma outra forma, porque você dá, assim, dá atenção aos mínimos detalhes. Coisas que às vezes você em casa, com uma criança normal, você passa despercebido, você não dá muita atenção, mas sendo uma criança que já faz um tratamento tão doloroso, já sofre, a gente tem um carinho especial. Todos os detalhes a gente pára pra observar, a gente pára pra dar atenção, por que às vezes em casa: "Ah, não dá, peraí, agora não!", não é? É assim, então aí é diferente: “Oi, que foi, filha, fala!”, a gente já... é diferente, é especial! (Mãe 7)

\section{Ser suporte para a criança}

Os comportamentos e atitudes colocados em prática ao preparar a criança para a batalha revelam-se em um papel da mãe da criança ao vivenciar o câncer do filho que é o de ser suporte para ela. A mãe revela para a criança quem é o seu inimigo e prepara a criança para a batalha, contando com a sua ajuda para lutarem juntas. Este papel envolve uma série de ações que envolvem dispor a criança em situação favorável para a batalha contra o câncer proporcionando-Ihe subsídios para que ela possa enfrentar a doença e não se entregar. Ser suporte é falar com a criança sobre a doença, estabelecendo um diálogo e mostrando para a criança o que é a doença de forma que ela possa compreender. Além disso, para ser suporte para o filho em tratamento, é necessário contar com a ajuda da criança nos procedimentos e na compreensão dos seus limites. 
A mãe não vive sozinha o tempo de luta contra o câncer do filho. Esta luta é também da criança e para que a criança possa lutar, a mãe precisa falar para ela sobre o que está acontecendo. Revelar a doença para a criança significa ser suporte para ela contando sobre a doença, explicando de uma forma que ela entenda e esclarecendo suas dúvidas. A mãe também estabelece um diálogo com o filho a fim de prepará-lo para procedimentos, intervenções, ida ao hospital e orientá-lo sobre as situações que irão enfrentar. Ela é suporte para a criança esclarecendo sobre a importância do tratamento para sua cura, mas também respeitando momentos em que não há nada a dizer. Além disso, revelar para o filho contra quem irão lutar significa não mentir, ser franca e não esconder o que está acontecendo ou o que irá acontecer. É falar sobre a doença na hora certa, e não ficar falando sobre isso o tempo todo, considerando que a criança continua sendo criança e a vida continua acontecendo para ser vivida. Ou seja, não é necessário falar o tempo todo, pois a doença não é a única coisa que a criança deve ter como foco de sua vida. Revelar para a criança quem será seu inimigo neste tempo de luta é uma situação na qual nem sempre a mãe sabe o que dizer, e a dificuldade em contar a verdade e falar sobre a doença com a criança muitas vezes estão presentes. Nestes momentos, para ser suporte para o filho na luta pela sua vida, ela utiliza os seus recursos como mãe, como sua habilidade em reconhecer as necessidades e respostas do filho mediante uma situação difícil e decide o que, quando e de que forma deve falar sobre a doença.

No dia que ele sentou no sofá e leu alguma coisa sobre isso e perguntou se ele estava com câncer, eu não tive coragem de falar. "Mãe, estou com câncer?". Eu parei, engasguei, e falei assim: "Não, você não está com câncer... Você está com um problema sério na medula que os médicos estão tentando resolver, que a gente vai procurar tratamento, você vai ficar bem, mas não é câncer". Aí ele falou: "Mas eu vi a A.M. na televisão sem cabelo e eu sei que ela está tratando de câncer e o meu cabelo também está caindo". É como se eu tivesse mentindo pra ele, mas eu não estava mentindo, eu estava só ocultando. Eu achava ele muito novo... Talvez seja percepção de mãe, eu não sabia a resposta certa naquele momento. Eu falei aquilo que eu achava que ele ia se sentir melhor de ouvir... Eu acho que 
acertei, porque depois ele olhou pra mim e falou assim: "Ah, mãe, graças a Deus, porque se hoje eu ouvisse isso, que eu estava com câncer, eu ia achar que não ía ter jeito pra mim". Se ele já começasse o tratamento pensando dessa maneira, a coisa poderia não evoluir como evoluiu. Com isso, com essa minha primeira experiência, que foi logo quando ele começou a quimioterapia, eu aprendi que a melhor maneira de lidar com esse choro dele, com esses momentos calados, com esses momentos de tristeza, é respeitando isso, por mais difícil que seja pra mim! (Mãe 2)

Então eu despertei para outros lados, outros sentidos, que talvez eu não teria. Eu procurei saber mais dele, o que ele sentia, o que eu podia fazer pra estar ajudando ele. Qual a dificuldade que ele tinha, o porquê, a gente começou a dialogar mais, apesar de no começo, ele tinha 3 anos só, mas ele sempre foi de perguntar tudo, e o que eu não sabia responder eu tentava esclarecer, pra passar pra ele de uma maneira fácil de entender também. (Mãe 3)

Eu lembro até hoje, quando foi diagnosticado o que ele tinha, ele virou pra mim, ele falou pra mim: "Mamãe, é sério o que eu tenho?", porque ele ouviu uma médica falando que era sério, que meu marido tinha perguntado, aí eu falei: "G., é sério, mas você não precisa ficar preocupado, filho, porque você vai sarar"... Eu falava, de qualquer modo, você entendeu, eu colocava o que era, mas ao mesmo tempo já dava que tinha solução. Porque criança, eu acredito que é assim: aquilo que você fala, pode passar anos, amanhã ou depois, vai ficar na cabecinha dele! Então se eu tivesse mentido, falado para ele que não era nada, que só uma gripe, ou que era uma tosse, eles mesmos... eles têm uma inteligência absoluta, eles sabem tudo, já nascem sabendo quase de tudo. Então a gente vê assim que não ia adiantar mentir porque ele ia cobrar de mim amanhã: "Poxa, mãe, você falou que não era tão sério, que era só uma gripe, alguma coisa assim, e como eu estou todo esse tempo, não saio do hospital?" Então não, sempre deixei claro, falei tudo o que era, do modo que ele pudesse entender, explicava. Quando tinha que ir pro hospital que ele sabia que ia ficar lá o dia inteiro, eu já falava: "Olha, amanhã a gente vai, é o dia que nós vamos ficar o dia inteiro".

"Ah, mãe", reclamava, como toda criança, mas ele já ia preparado para aquilo. Você entendeu? É diferente de você chegar, amanhecer o dia e falar "Vamos filho, vamos para o hospital.", "Mas hoje eu tenho, mãe, hoje eu tenho que ir?". Então é diferente você já ir preparando a criança para aquilo. Ele sente mais seguro, ele sente, entendeu, já vai amenizando. (Mãe 3)

O dia que eu descobri a doença dela, foi difícil pra mim chegar e contar, né? Aí, quem contou foi uma amiga minha que é pediatra. Aí quando ela foi contar pra ela, e ela começou a contar pra L. assim, com a estória da borboleta, a transformação da borboleta, como é que a borboleta passa a ser uma borboleta, toda aquela transformação da lagarta, tudo, 
então a L. aceitou, entre aspas né? Mas ela ficou preocupada, tanto é que um dia, a $L$. chorando, aí eu fui, conversei com ela novamente, expliquei, fui muito clara, fui muito clara com ela, eu disse, "Olha, você tem essa doença na sua barriga, que está crescendo, a gente vai ter que fazer um tratamento, vai cair o seu cabelo..." Expliquei tudo... (Mãe 5)

Ela está enfrentando tudo muito bem. Eu digo pra ela: "Nada eu vou esconder de você!" Tudo que ela vai fazer, eu conto pra ela, eu explico, eu mostro o desenho... Eu vou na Internet, eu mostro, "Olha, isso aqui, isso, isso..." Quando ela vai fazer o mielograma ela sabe como é, o líquor, eu explico... Na véspera da cirurgia dela, eu lembrei da minha quando eu tive ela. Aí peguei, comecei a falar pra ela, como foi, o corte, que eles deram a anestesia, só que eu quis ficar acordada, não quis dormir, aí eu não sentia as minhas pernas, aí eu disse pra ela: "Só que com você vai ser diferente, você vai dormir. Aí vão cortar a sua barriga bem no meio, vão tirar o carocinho que está dentro da sua barriga, aí depois vão costurar... Quando você acordar vai estar tudo costurado". Aí mostrei a minha...E ela aceitou numa boa também, aceitou, aí consegui ir pra sala de cirurgia segura, aceitou também. Tanto é que na sala de cirurgia, quando acabou a cirurgia, a menina levantou. Ela sentou na mesa, tiveram que deitar ela rápido... Sentou, menina! Mas ela ficou super bem, não escondo nada, nada dela. Eu digo, "Ó, quando doer eu vou te falar, se não doer, eu vou dizer também que não vai doer. Eu não vou te esconder nada, nada, nada! Eu quero só que você confie em mim..." E a gente vai até hoje, super confiante. Tanto é que ela não gosta, quando eu pai está aqui, eu digo: "Vai com o pai hoje lá pro hospital", "Ah, não mãe, que quero ir com a senhora". Ela não vem com o pai, só comigo, ela confia em mim, não confia em outra pessoa pra estar com ela, entendeu? Eu passei a confiança pra ela, e está aí, a L. está enfrentando numa boa. (Mãe 5)

Então, quando eu contei pra T. o que ela tinha, eu falei pra ela assim, ela tinha sete anos, e eu falei: "Filha, você tem uma doença", não escondi nada, falei: "você tem um câncer, não é tão fácil de curar como uma gripe, a gripe é muito mais fácil... Só que ela dá um pouquinho de trabalho, só que a gente vai cuidar e a gente vai vencer". Eu nunca escondi e falei que realmente a gente ia ter que lutar bastante, ia ter que ser forte, mas estamos aí, para o que der e vier, entendeu? (Mãe 7)

De início ela não sabia, eu não contei pra ela que o médico tinha falado que ia amputar. Primeiro eu queria saber o que esses aqui iam falar. la ter a hora certa de contar pra ela isso. Aí quando eles disseram que não precisava, que a gente ia ficar aqui, se a gente quisesse lógico, ela questionou: "Porque eu tenho que ficar aqui tão longe? Eu quero a minha família, eu quero ficar perto dos meus primos, perto do meu pai..." Eu falei, "Agora é o momento". Aí eu não precisei nem falar pra ela, ela mesmo foi muito esperta, foi colhendo, aí nós sentamos para conversar e falou: "Mas eu sei porque... Porque lá eles iam tirar a 
minha perna, né?" Falei: "É. Você prefere ficar lá?", ela: "Não mãe, não quero, eu prefiro ficar aqui". Aí ela com certeza entendeu, o porquê, mesmo a gente estando longe da família, do pai, de todo mundo, dos primos que ela adora, mas é preferível ficar aqui por um período para ela poder tentar conservar a perninha dela. Aí agora a gente está lutando de novo. $O$ médico falou que ela precisa tomar essas quimioterapias pra poder, o tumor diminuir, e eu creio que ele vai diminuir, pra eles fazerem uma outra cirurgia, que também não vai ser amputação, que eles vão conseguir tirar esse tumor e conservar a perna dela. Mas isso agora ela já sabe. Eu não fico também falando a todo momento, porque não tem porque, a gente deixa fazer o efeito da medicação porque aí a gente vê o que o médico vai falar.

(Mãe 7)

A mãe não somente busca falar sobre a doença com a criança na hora certa, da forma que considera adequada por conhecer melhor do que ninguém o seu filho, mas também busca Preparar a criança para a batalha. Significa fortalecê-lo de forma a não permitir que ele desanime, ou seja, fortalecê-lo a fim de não dar a chance de perderem a luta. Significa ser o suporte para a criança ao vivenciar a dor e o desconforto provenientes da doença e seu tratamento. Preparar a criança para a batalha exige ser mais paciente e tolerante, pois o filho precisa dela naquele momento. É transmitir força e segurança, cultivando na criança a esperança de que tudo vai dar certo. Envolve também ser amiga, respeitando seu silêncio quando não quer falar sobre a doença, dar apoio em uma situação difícil, amparar durante e depois de um procedimento doloroso e estender a mão, proporcionando-lhe segurança. A mãe faz tudo isso porque sabe que este é um momento na vida do filho no qual ele precisa muito do seu apoio, inclusive que esteja preparada para agir nos momentos em que não está bem. Para ser suporte da criança preparando-a para a batalha contra sua doença, a mãe procura passar força para ela em todos os momentos e nunca se mostrar enfraquecida, desabafando e chorando em um lugar onde a criança não a veja. Para a mãe, deixar transparecer seus momentos de fraqueza, angústia e desespero aproximariam a criança da idéia de que há algo errado, quando na verdade tudo que ela precisa é acreditar que vai dar certo. 
Quando ela teve a mucosite, quatorze dias lá na cama. Aí quem teve que ter força de leão foi eu! Pra segurar a barra porque ela ficou muito revoltada, tinha dia que, teve vez que três enfermeiros teve que segurar ela, ela ficou revoltada demais... Aí ela queria comer, ela tinha fome, não agüentava. Por que a mucosite dela foi muito feia, muito feia mesmo. $E$ em casa, também, ela teve alta e ficou mais quatorze dias com a boca ferida. Em casa ela quebrava as coisas, você tentava dar alguma coisa pra ela comer, ela jogava longe. Então teve muita dificuldade nesse tempo, foi a pior parte, eu não desejo pro meu maior inimigo. Ela chorava a noite, ela gritava. A Dra. C. que eu cheguei e falei com ela, foi aí que eu conheci a Dra. C., foi quando ela teve a mucosite... Falei pra ela que eu não agüentava mais, que eu nunca tinha visto a minha filha desse jeito, minha filha não era assim, que ela tava revoltada, tava fazendo isso, fazendo aquilo... Foi aí que ela falou pra mim: "Mãe, ela tá revoltada com você, porque é você quem traz ela para o hospital, é você quem fica com ela, é você não sei o quê..." Foi aí que eu conheci a Dra. C., foi a fase mais difícil, foi mais difícil do que eu ficar sabendo o que ela tinha. Te juro! (Mãe 1)

Então eu sempre procurava passar esse lado pra ele, de uma mãe fortalecida, uma mãe que queria estar ajudando, dando o que eu não tinha de mim pra ele, procurar... Mas não é fácil, porque você tem que ter muita fé, tem que confiar, principalmente ter a confiança no médico, nos enfermeiros, né? (Mãe 3)

O dar o carinho para a criança, a gente aprender, eu aprendi isso, que é muito importante você passar atenção, você aprende a ser mais atenciosa, mais paciente. Ter paciência de uma forma assim, que você às vezes pensa que não é capaz de ter. Porque situações às vezes assim, tão complicadas, você vê o filho chorando, o filho nervoso, porque mexeu muito com o sistema nervoso dele, toda a medicação, e naquela hora você ser paciente. Eu lembro quando a gente ia de ambulância e voltava de ambulância pra casa, ele ficava assim, meio que nervoso. Se o motorista corria um pouco mais, ele achava tava correndo

muito, que ia virar, ia doer, irritado, sabe? Às vezes me xingava: "Ah, mãe!", bravo, e naquela hora você ser paciente, sabe, você respirar e falar: "Não, o meu filho, ele não está bem, ele não está falando isso porque, vamos dizer assim, seja falta de educação, alguma coisa assim, mas é devido ao tratamento, as conseqüências do tratamento, deixou ele assim... Então perante essa hora eu vou tentar ser paciente o máximo paciente que eu puder para poder estar ajudando ele nesse ponto". Então eu acho que é isso, a diferença é buscar essa paciência, essa compreensão, que às vezes a gente não tem, né? Muitas vezes a gente fala: "Ah, já que está bravo, então vai ficar, ou não sei o quê..." Não... Você ser paciente até o último, que você consegue o aquilo você espera. (Mãe 3)

Porque eu acho que se eu não tivesse essa força que eu busco que é em Deus em primeiro lugar, eu não sentiria forte porque pelo meu marido, ele foi muito fraco perante a situação! 
Então qualquer coisa ele chorava, ele ficava todo emocionado, tal... E não que eu não tenha ficado, porque a gente tem coração, a gente é humana, a gente tem sentimento. Mas eu procurava desabafar em uma hora que talvez ele tivesse dormindo, uma hora que eu tivesse pra fora da sala, alguma coisa assim. Mas pra mim, pra mãe, eu acho que é um buscar lá dentro, assim, sabe, você ir lá no fundo mesmo, conscientizar, respirar e falar: "Não, eu tenho que ser forte, porque eu tenho que passar fortaleza pro meu filho. Se eu for fraca perante ele, ele também vai ser fraco", entendeu? Então eu sempre procurava passar esse lado pra ele, de uma mãe fortalecida, uma mãe que queria estar ajudando, dando o que eu não tinha de mim pra ele, procurar... Mas não é fácil, porque você tem que ter muita fé, tem que confiar, principalmente ter a confiança no médico, nos enfermeiros, né? (Mãe 3)

A A. sempre foi muito forte, parece que Deus já deu o dom, porque já sabia o que ela ia passar. Ela sempre quer que eu conte o que vai fazer no hospital. Quando tem um exame que eu não falo para ela, ela fica brava. "Porque escondeu de mim?". Na primeira cirurgia, eu escondi e ela ficou brava. O pai achava melhor não falar para não sofrer antecipado. Mas não sei se é bom esconder, não. Por pior que seja, ela fala: "Já que tem que fazer, vamos logo!". (Mãe 4)

Ela nunca foi necessário ir a um psicólogo por causa da doença... Eu digo: "Não quem tem que ajudar a minha filha sou eu mesma", e eu procuro ajudar ela ao máximo! Eu sou muito franca com ela. Ás vezes o que eu falo ela até chora. Ás vezes, machuca, ela chora dói, mas ela chora, mas ela pensa, depois ela vê que eu falei pro bem dela. Eu digo, "Olha, eu não falei pro seu mal, eu falei pro seu bem. Eu não quero ver você pra baixo, você tem que se erguer, L., não pode ficar pra baixo, não pode se deixar abater". Aí eu mostro pra ela o exemplo de outras crianças que estão piores que ela, sem perninha, sem braço, aí eu digo pra ela "Você tem que levantar, você está bem, você não tem nada! Você não pode deixar". Sabe, o adulto adoece mais rápido por causa da cabeça... Ele se deixa abalar... E a criança não... Se for natural, ela vai embora, e supera rapidinho... (Mãe 5)

Eu nunca, eu não choro perto dela... Eu tive uma fase que eu chorava todo dia, mas eu só chorava de noite... Ela tava dormindo e eu me desabava a chorar... Dentro do quarto, no escuro, mas na frente dela eu não choro, de jeito nenhum... Sempre eu to aqui, firme e forte... Se eu começar a lacrimejar eu vou pro banheiro e lavo o rosto, eu volto de novo, bebo uma água... E assim, eu estou levando até hoje, e se Deus quiser falta bem pouco pra gente terminar com tudo isso... (Mãe 5)

Foi no dia 11 de fevereiro, ela tava tomando sangue, ela começou a tremer, quando eu olhei os dedos dela todo roxo, dedo do pé... aí eu comecei a ficar preocupada... Aí eu chamei a enfermeira, eu fiquei apavorada, mas assim, eu ajudei ali naquela hora, passou tudo eu 
chamei a enfermeira, aí veio o médico, olhou, passou, tudo, depois que passou tudo, aí eu chorei, chorei... Enquanto ela tava passando mal eu reagi, né? Fui atrás, resolvi, mas depois que passou, a L. tava bem, pronto, eu desabei a chorar que eu não conseguia nem falar. Depois... Acabou... Nessas horas que eu choro, sabe, eu fico desesperada mesmo, se eu vejo ela passar muito mal, eu fico desesperada... mas fora disso, não... Eu to conseguindo passar força pra ela... E eu estou conseguindo, graças a Deus. (Mãe 5)

É assim que eu me vejo hoje em dia, entendeu? Só batalhando em função deles! O que eu puder fazer pra ver eles bem, eu vou fazer, eu vou fazer sempre! (Mãe 6)

Porque eu, procuro assim, eu sou uma pessoa muito positiva, sempre pensando o melhor, sempre pensando que vai dar tudo certo. Não vou te dizer que é fácil, não é fácil. Mas a luta é grande, mas a gente tem que estar sempre com força, até para dar força pra eles, porque eles precisam. Se eles, as crianças verem que a gente está triste, pessimistas, aí eles acabam achando que "poxa, é o fim do mundo, né? Não tem jeito...". (Mãe 7)

Ela também tem muita força, ela também me ajuda bastante, nisso tudo. Sabe, ela também é uma criança que está sempre pra cima, está sempre buscando... Ela acostumou, a gente conversa muito, eu procuro tirar todas as dúvidas dela que tem que esteja no meu alcance, o que eu não sei eu busco pra poder saber falar pra ela, e a gente vai...Eu tento ser amiga dela pra gente poder estar sempre junto, ela ter confiança em mim, e a gente vai seguindo... (Mãe 7)

Para ser suporte para o filho, a mãe precisa Contar com a ajuda da criança, já que a luta contra o câncer é de ambos. Isso significa que a criança também tem um papel importante na experiência da doença colaborando com a mãe e com a equipe na hora de fazer um exame, de puncionar um acesso, de não poder comer ou fazer algo que deseja. A mãe considera que tem coisas que a criança já compreende e pode cooperar para facilitar os procedimentos e o cumprimento das restrições decorrentes ao tratamento. Contar com a ajuda da criança neste tempo de luta torna mais amena a difícil tarefa de ser mãe e permite que suavize o preparo da criança nesta batalha. 
Tanto é que, graças a Deus, ela não me dá trabalho, a C. hoje mesmo hoje ela tava comentando... Ela nunca me deu trabalho pra puncionar, pra tirar sangue... Pra nada! Pra nada, nada... Pra tomar remédio é uma maravilha, adora tomar remédio. É que nem eu falei, Deus dá o frio conforme o cobertor, porque o meu outro filho de onze anos ele é triste pra tomar remédio! Ele morre com dor, mas não toma. Ele põe na boca, tira. A A. ela toma os comprimidos assim, que às vezes passam pra ela, desse tamanho, eu coloco na boca dela: "Mãe, ó, engoli!" (...) Então, não tive problema nenhum com ela pra fazer os exames. Pra você ter uma idéia ela foi fazer uma biópsia de medula, logo no começo, ela ficou de jejum, mandaram ela parar de comer oito horas da noite, pro dia seguinte, um dia antes. Ela foi fazer essa biópsia às duas horas da tarde, e ela não me deu trabalho. Com fome, nem água ela podia tomar! Ela fez a biópsia, no outro dia ela tava pulando, brincando, não teve nada. E até hoje ela é assim, ela não dá trabalho. As enfermeiras mesmo falam, a A. não dá trabalho pra puncionar, pra tirar sangue, não chora, pra tomar remédio, ela não dá trabalho, não... O único trabalho que ela me dá é que ela é uma pimenta! (Rs...) É porque agora ela está assim, tipo assim, meio injuriada, já de tanta coisa, mas no começo ela fazia quimioterapia dando risada, brincando o dia inteiro, chamando, gritando as enfermeiras, mexendo com um, mexendo com outro, pergunta pra elas, pra M.... Mas agora ela está meio enjoadinha, né... Acho que conforme vai passando o tempo eles fica mais estressado... (Mãe 1)

E acho importante a criança se ajudar também, cooperar, porque tem coisas que ela entende. Que nem ontem, na ressonância. Ela tava se mexendo e o médico disse que assim não conseguiria fazer e que achava melhor sedar. Aí eu disse que não, que ia conversar com ela. Aí pedi que ela colaborasse, que não iriam sedar porque ela já podia entender o que seria feito. Então tem se ajudar também, senão fica difícil. (Mãe 4)

Eu até agradeço a Deus porque ela é muito boazinha, sabe, ela me compreende bastante. A gente tenta conversar, e ela está sempre, é claro que na medida do possível, de uma criança, né, mas ela me tenta entender e seguir as coisas que eu falo, que é pro bem dela, né? Entendeu? É meio dengosinha, dengosinha é, mas também filha única, né, sabe como é... Carinhosa, filha dedicada... (Mãe 7)

\section{Fortalecer-se na batalha}

O fortalecimento da mãe na batalha contra o câncer da criança envolve primeiramente assumir para si mesma que aquela luta contra a doença que ameaça sua vida é também uma luta sua. Assim, é preciso 
encarar essa luta como algo que ela tem que enfrentar e não pode fugir. Para isso, é preciso buscar elementos que a fortaleçam a cada batalha, como a fé e a esperança de que aquela luta vale a pena. Para fortalecer-se na batalha é preciso também cuidar de si mesma, já que é uma pessoa que também sofre e tem a necessidade de recarregar essas forças, assim como cuidar da sua família, buscando a compreensão e suporte mútuo.

Buscar forças para lutar significa buscar elementos importantes para assumir a batalha contra o câncer do filho, já que essa luta também é dela. $A$ mãe busca força através da fé e da esperança de que tudo vai dar certo, da crença de que Deus está ao seu lado nesta luta, bem como das situações difíceis na vivência da doença. Ela acredita que pode suportar tudo o que está vivendo, pois tem um elemento que the serve de estrutura: a esperança e a confiança em Deus. O fortalecimento também se expressa no pensamento positivo e em coisas boas. Ao buscar forças para lutar, a mãe sabe que existem muitas pessoas que podem e estão dispostas a ajudar a ser forte e the oferecer apoio: os familiares, amigos, voluntários e profissionais do hospital e outras famílias de crianças com câncer. A esperança dos médicos na cura da doença do filho lhe dá subsídios para seguir em frente e não fugir da luta. É uma interação no qual a confiança se configura como um elemento fundamental. Além de buscar forças para si, ela busca ser a fonte desta força para outras mães. Ser fonte e ao mesmo tempo receptora dessa força representa momentos que se intercalam na construção de relações sólidas de ajuda entre as mães que vivenciam o câncer de seus filhos.

A gente escuta muita coisa, aqui, por exemplo, morte de criança, morte dali, só que a gente não pode pensar por causa do outro, cada um tem um caso diferente e hoje em dia eu... se fosse um tempo atrás eu acho até... poderia até ficar desesperada, mas hoje em dia não. $E$ os médicos também deram esperança pro caso dela. No caso dele eles deram esperança, que ela ia ficar boa, que ela ia ficar curada porque ela não tem massa cefálica, é isso que falam? É? Em outra região do corpo... Metástase...Isso. É só ali mesmo. Que ela ia ficar boa, que ia ficar curada. Me deram, me deu esperança pra lutar e seguir em frente! (Mãe 1) 
Eu não sei, não sei explicar sobre esse negócio de força, só, que só, a explicação que tem é que só Deus mesmo pra dar força pra gente. Eu acho, acredito nisso!

Eu acredito nisso, que só Deus mesmo pra dar força pra gente, pra ver o estado que minha filha ficou quando ela ficou internada por mucosite, foi muito triste... Olha, foi muito triste, foi a época mais triste que eu tive, foi quando ela ficou internada por mucosite. (Mãe 1)

A força que a gente busca é assim... Primeiro você exercita mais a sua parte espiritual. Isso na religião que você pertence, que você procurou, isso depende de pessoa pra pessoa.

Depois, aqueles amigos verdadeiros, as pessoas que você gosta, você procura, você ouve uma palavra, quando você tem pessoas, assim, que estão junto, pra conversar, mesmo pra te fazer uma visita, isso já é uma força! Você ter com quem conversar, isso vai te dando...

Você vai se sentindo também importante, você vê que não está só.

Então são nessas coisas, primeiro na parte espiritual, depois nas pessoas amigas, que no meu caso, como meus parentes são distantes, moravam longe da minha cidade, moram, eu não tive tanto apoio da minha família devido eles estarem longe.

Mas os amigos verdadeiros, eu contei com bastante gente. Isso é muito importante! Essa força vem daí. (Mãe 2)

Onde eu busquei? Primeiramente em Deus, que a gente sempre foi, de religião, a gente sempre foi católico, e eu sempre fui de ajoelhar mesmo nos pés do Senhor e falar, sabe, pedir: "Senhor, não me abandone nessa hora". Porque eu acho que a gente tem que crer, tem que crer que Deus ele não quer as pessoas, os seus filhos, com doença, ou... Então eu vi que eu tinha que buscar uma força, e essa força em primeiro lugar foi em Deus. Depois foi na... Na confiança da equipe médica, que eu busquei também essa força, o desvendar o que era uma leucemia, que grau que estava, o conhecer um pouco do que era o câncer. Então isso também que foi pra mim onde eu pude buscar essa força, o saber realmente $o$ que o meu filho tava tratando, porque até aí eu não conhecia, eu era totalmente leiga, não sabia nada do tratamento, o que era, como era, não sabia que tinha vários graus, e que tinha, que nem o dele é só no sangue, né? Então foi assim, foi buscando pra mim poder ter forças. (Mãe 3)

E é nisso que eu me seguro, eu acredito que tem um Deus do meu lado, entendeu, que me dá força, eu peço muita força pra Ele, aí é assim que Ele me dá... Na véspera da cirurgia, eu rezei muito a noite, pra Ele me dar força pra eu não chorar na frente dela de jeito nenhum, pra eu transmitir força pra ela entrar na cirurgia. E eu consegui fazer isso, eu não chorei, ela entrou na sala de cirurgia bem, a cirurgia dela foi rápida, entendeu... Quer dizer, eu me seguro nisso, é Ele que está do meu lado, dando força a mim e a ela. É aí que eu busco 
minha força, é Ele que me dá, não tem mais ninguém pra dar, né? A não ser Ele, tem gente que não acredita, mas eu acredito. E muito! (Mãe 5)

Eu busquei força da onde eu não tinha. Dentro de mim... Que nem eu te falei, no começo te derruba, você não sabe como vai ser, você fica totalmente frágil, sem saber de nada. Mas aí depois você põe a cabeça assim, parece que te dá aquele chocoalhão, assim e fala: "Se essa é a minha sina, eu vou lutar! Vou lutar até o fim e seja o que Deus quiser! E vamos lá". Aí chega aqui, tem casos, sabe, nossa, um menino tinha tratado, parecia outra pessoa, tinha o tamanho dela... Que nem um menino ontem, 18 anos já, eu falei: "Nossa, que maravilha, que bom que você está bem", ele falou "Que bom mesmo, a sua também vai ficar bem", eu falei "Se Deus quiser, vai sim". Então, assim, isso acaba te dando força. Aí vêm os voluntários, quando vê que você está um pouco triste, tem o "cantinho da paz" lá em cima, você sobe, tipo assim, quando a $A$. fica internada, às vezes está meio ruinzinha, às vezes está demorando pra sair, eu subo lá cima, dá aquela paz, entendeu? Aí vem os voluntários, conversam comigo, "Precisa de alguma coisa?"... (Mãe 6)

Essa força que a gente busca vem de Deus. Um pouco antes de ela ter esse problema, nós começamos a seguir a religião evangélica, e eu sempre, realmente, se eu não tivesse com Deus e não sei como seria, porque Ele que me dá essa força, sabe... Essa, como é que eu vou dizer, essa certeza de que no final tudo vai dar certo. Entendeu? Que a gente tem lutas, que a gente passa por lutas, mas a gente confia que vai dar certo. (Mãe 7)

Assumir a luta pela vida da criança é fazer tudo isso de cabeça erguida, mesmo que sozinha, se entregando ao filho doente e assumindo o que ela encara ser sua missão: lutar pela vida da criança para que ela fique novamente bem e curada. Para ela, não é possível fugir da realidade de que seu filho está vivenciando uma doença. Por isso é preciso seguir em frente, se mantendo firme, acreditando que pode suportar tudo aquilo que está vivendo. Para a mãe, essa situação difícil aconteceu na sua vida porque é capaz de superar. Assim, ela assume a luta pela vida da criança, enfrentando as barreiras do tratamento e lutando quantas vezes for necessário, já que tudo o que quer é ver seu filho bem e que ele se cure de qualquer jeito. Assumir e viver a luta pela vida do seu filho é algo que a faz buscar mais forças e saúde, para suportar as demandas da doença e tratamento e poder permanecer junto à criança sempre atenta às suas 
necessidades. Acreditar que a realidade é algo concreto e não há como escapar faz com que a mãe assuma a luta pela vida do filho como algo que Ihe foi conferido, e isso a mantém disposta a prosseguir, batalha após batalha de uma luta longa e difícil.

Por que todo mundo trabalha lá em casa, minhas irmãs, meu marido, e só fica mesmo eu e minha mãe, que eu moro em cima da casa da minha mãe, né? Então eu tenho que ter saúde, força, pra correr atrás de tudo, médico, internada é eu que fico, porque ela não quer ninguém, ela só quer eu, que eu fique com ela... (Mãe 1)

Que não é que Ele escolhe as pessoas... Eu acho, não é que Ele escolhe, mas permite que aconteça, uma pessoa assim, por exemplo, que nem uma irmã que eu tenho, lá, eu acho que ela não iria agüentar! Porque tipo assim, que nem eu te falei, se fosse com meu outro filho? Seria mais, um exemplo que eu to te dando, seria mais problemático pra tratar dele, entendeu? Porque ele pra tomar remédio ele é triste, pra tirar sangue, desde neném, sempre, sabe, deu trabalho, pra tomar injeção, tudo... É que nem assim, aquele ditado, que Deus não dá um fardo pesado, dá aquilo que você possa suportar, agüentar, entendeu?

(Mãe 1)

Eu sempre fui uma mãe muito dedicada, desde que eles nasceram, eu não saia mais, eu vivia muito pra ele, sempre vivi pra ele. Só que é aquela coisa, eu resolvia os meus problemas e os problemas dele sozinha! Eu achava que eu era suficiente pra resolver os problemas dos meus dois filhos. Então antes eu era assim, eu fazia, eu corria atrás, e hoje, com o aprendizado desse tempo, quatro anos de problema, eu acho assim, que tem que ter mais estrutura da família e eu... Eu me sinto mais mãe, mais tranqüila, mais serena, pra compreender também a parte do marido e do pai, e do homem também, em relação tanto a eles quanto a mim. (Mãe 2)

Primeiramente vem a culpa, o por quê, então esse é sentir o pé no chão, sem ter pé no chão, você sentir flutuando mesmo... Depois quando você, como que eu falo, assim... Debate, você vê outras crianças, quando eu entrei no G. e vi outras crianças iguais a ele... Quer dizer, ele ainda não tinha ficado daquele jeito mas ia ficar, né? Então, aquilo, eu falei: "Não, aqui eu vou ter que buscar, aqui eu vou ter que ser forte, né? E aqui eu vou ter que sentir meus pés no chão novamente, eu tenho que sentir que eu não posso fugir da realidade, que eu tenho que assumir isso que está acontecendo e eu tenho que encarar de frente mesmo para eu conseguir passar alguma coisa pro meu filho, né?" Que já pensou uma mãe ela se sentir totalmente fora de si, o que vai fazer, o que deixa de fazer, e 
acompanhando a criança? De que forma você ia acompanhar? Se nem você sentia, você não sabia como receber aquela notícia, depois que recebe então... Como você poder ajudar uma criança se você não está bem, se você não está com seu pé no chão ali, sentindo que pode fazer algo? (Mãe 3)

Por que assim, no dia que eu recebi a notícia, porque eu sempre falava, engraçado, uma semana antes eu tinha comentado pra minha irmã, eu disse pra ela assim: "A vida é interessante, a gente nunca sabe o dia de amanhã, olha só, eu to bem aqui, V." Meu marido tinha acabado de trocar de cargo, a gente tava super feliz, mas eu disse assim: "A gente nunca sabe o dia de amanhã, quem sabe é Deus". Quando foi uma semana depois, eu descobri o caso dela. Aí eu disse: "Se Deus me deu a missão, ele vai estar junto comigo pra me ajudar a cumprir!". E é nisso que eu me seguro, eu acredito que tem um Deus do meu lado, entendeu, que me dá força, eu peço muita força pra Ele, aí é assim que Ele me dá...

(Mãe 5)

É como se fosse sua missão. Tem que ter, vou cumprir, vou enfrentar de frente! Entendeu? Busco de lá de dentro de mim mesmo. Então é isso que me mantém! Vamos supor, hoje, essa força que eu tenho vem de dentro de mim, de ver ela bem, essa é minha força, de vontade, é o que eu mais quero ter, é ver a minha filha saudável de novo. É essa força que eu busco dentro de mim. (Mãe 6)

Enfrentamos, e se tiver que enfrentar algumas barreiras também tem que enfrentar, né? Não andar pra trás, tem andar pra frente... É assim que eu penso... (Mãe 6)

A gente tem que ver e pensar no porquê de a gente estar aqui. Por que será, né? Tem alguma coisa do porquê da gente estar aqui, passando por isso tudo. O que a gente tem que tirar de proveito, né, disso tudo. E eu acho que o proveito é esse. É a atenção, o carinho, tanto a ela quanto ao próximo, sabe, esse amor a vida, essa esperança que a gente sempre tem que ter, se agarra, né, pra viver, pra lutar pela vida deles. Então eu acho que isso tudo a gente vai aprendendo aqui, vai tirando... (Mãe 7)

Cuidar de si é procurar restabelecer suas energias para prosseguir na luta que assumiu pela vida do filho. Vivenciar a experiência de ser mãe de uma criança com câncer exige um sacrifício sem limites. Tudo que está ao seu alcance é possível de ser feito para manter a criança viva, junto dela. Assim, a cada batalha contra a doença, a mãe passa a viver mais para 0 filho que está doente do que para si mesma, se esquecendo muitas vezes 
das suas próprias necessidades, o que a deixa cansada e enfraquecida. Ela precisa recarregar suas forças, o que faz aproveitando os momentos de lazer que pode usufruir com a família. Desta forma, cuidar de si é um combustível para se manter firme na batalha pela vida do filho; é algo que ela considera importante não somente para si, mas para prosseguir na luta que assumiu.

O que nós, mães, pudermos fazer, pra melhorar a vida deles, independente do tamanho que seja esse sacrifício, eu acho que a gente tem que fazer. Agora uma parte importante também é você não se deixar totalmente de lado, entendeu? Isso, no começo, você não pensa, mas com o tempo você vê que é uma coisa importante, é que você procure, que se você estiver bem, você colabora melhor com eles! É a minha forma de ver (...) Como foi que eu exagerei, que eu acho... Eu exagerei assim... Com relação ao marido em casa, por exemplo, eu... Aquilo que eu falei ontem, eu tava revoltada, eu não aceitava ele como... Eu achava que ele não tinha que se meter em nada, que eu tinha que decidir tudo sozinha, na verdade eu deixei ele um zero à esquerda. E... Eu deixando ele de lado, eu também não pensava, não pensava na minha saúde, eu não pensava no que a gente, eu e ele tinha construído até aquele momento, então eu fui me deixando, eu não pensei em me cuidar, eu não pensei em procurar um psicólogo, eu achava que eu tinha que resolver tudo. Aí nesse sentido você se deixa de lado e exagera na dose. É quando você acha que pode resolver tudo sozinha, esquece da sua saúde, esquece da sua parte psicológica, esquece... E não é

bem assim! Se eu sou mãe e ele é pai, tem que ter a participação dos dois pra poder caminhar.

(Mãe 2)

Porque ao mesmo tempo que a gente tem que ser forte, em um certo momento que a gente se sente enfraquecida, com toda situação que está passando, você fica assim, enfraquecida. Tem uma hora que você também, como ser humano, precisa recarregar essas forças pra você passar pro seu filho. (Mãe 3)

Ah, é difícil porque você se sente cansada, às vezes você fala assim: "Meu Deus, tanto tempo, eu estou tão cansada...". Às vezes você passa o dia todo aqui, sentada, do jeito que eu estou, deitada aqui com ela, no colo. Aí você chega em casa parece que você andou o dia inteiro, uma falta de ânimo, você olha pro filho, ele "Ah, mãe", isso, isso, isso... "Fiz isso na escola", "Ah, meu filho, está bom, amanhã a gente conversa direitinho, a mãe não vai pro hospital, a gente conversa direitinho, vamos dormir que a gente conversa amanhã...". Sem 
ânimo... Totalmente sem ânimo "Ah, mãe, mas me pega no colo", "to tão cansada", e ele tão grandão pra ficar no colo... (Mãe 6)

Cuidar de mim também, porque eu também preciso. Porque às vezes as mães acabam esquecendo de cuidar delas, só que eu digo, eu penso assim: "Eu preciso cuidar de mim pra ter forças pra cuidar dela". Tanto na área física, quanto espiritual também. Eu preciso estar sempre bem, para poder dar forças pra ela. (Mãe 7)

Para se fortalecer na batalha, é preciso também Cuidar da família, na qual ela tem seu papel. Manter a integridade familiar e a estrutura da família na situação de batalha contra a doença de um filho é algo importante. A fim de alcançar ou manter este ambiente, procura ser mais maleável e estar o mais próxima possível do esposo e dos outros filhos. A mãe busca compreender e ser compreendida através do diálogo, tendo como objetivo a união entre os membros da família. A mãe, apesar de todas as exigências do tratamento, procura cuidar da casa e dos filhos e lhes oferecer atenção, bem como ter a certeza de que eles estão bem.

Mas é assim, com o tempo, com esse aprendizado que eu estou te falando, a gente vê que o básico de qualquer família que passa por isso, se a gente souber conciliar pai junto, mãe, irmão unidos, a melhora da criança é bem superior como naquele período que a coisa já não andava tão bem no ambiente familiar! A coisa se supera, entendeu? Quando a coisa não vai bem no ambiente familiar a criança em si não se sente... tão bem e não evolui tanto quando a coisa está mais equilibrada! Foi isso que eu aprendi nesses quatro anos. (Mãe 2)

A estrutura da família é manter a gente unido, né... É a conversa entre eu, o pai, os dois.....é não deixar que o J. sinta falta do irmão, do A., e se o A. tiver que sacrificar um pouquinho as férias dele, por exemplo, pra ficar mais em casa com o J., ele vai ficar, conversando bastante, mesmo com a idade de onze anos, eu não sei se ele entende bem, mas ele vai ficar porque é importante pro J. se sentir bem. Agora ele passa três, quatro dias

fora, na casa de um amigo ou de uma irmã, e o J. chora, sente falta. Então, mesmo sacrificando um pouquinho as férias do outro, que não está em tratamento, a gente sacrifica pra ver o irmão, o que está doente, se sentindo melhor. Então a estrutura em si é isso. É poder me sentir bem na união em casa, entre os quatro, pra que os quatro participem, 
mesmo meu filho com pouca idade, o outro. Ele tem que compreender, tem que participar, essa é a estrutura que a gente sempre busca.

Em relação à parte financeira, que hoje eu to trabalhando, no primeiro tratamento eu parei dois anos, mas o financeiro hoje pode não ser, assim, o suficiente pra gente viver bem, mas sendo só o suficiente pra gente sobreviver, a gente estando os quatro unidos pra ele se cuidar melhor, pra gente, eu tenho certeza, pra mim já está ótimo. Entendeu? É por aí...

(Mãe 2)

Estou tranqüila que minha filha está bem lá, eu falo com a minha filha todo dia, eu vejo minha filha pelo computador, eu vejo me marido, converso com ele, a hora que dá ele vem aqui, eu to tranqüila. Minha família está estruturada, não teve, assim, nenhum desfecho por causa da doença dela. Tem muitas famílias que isso destrói, né... Por causa da doença... A minha não, até agora... parece que uniu mais ainda. (Mãe 5)

Quando tem um tempo assim, pra lazer, que ela está bem, que a gente está tudo bem, a gente aproveita. Eu concordo, assim, de estar saindo pra aliviar o estresse dela e da gente também. (Mãe 6)

\section{Sentir-se mais mãe}

Ao vivenciar a luta pela vida do filho, protegendo e sendo suporte para ele, buscando se fortalecer e fortalecer a criança na luta contra a doença, a mãe é capaz de Sentir-se mais mãe. Esta categoria que representa uma redescoberta do seu próprio papel como mãe e permite atribuir um valor maior a si mesma, a tudo que é capaz de fazer, à criança, às coisas que antes eram consideradas pequenas e à própria vida. Antes da doença, a mãe sempre cuidou do filho, mas agora, sendo mãe de uma criança com câncer, ela cuida mais; ela sempre protegeu o filho, agora ela protege mais; ela sempre foi suporte para a criança, mas agora ela é mais... Assim, ela sempre foi mãe, mas agora se sente mais mãe.

$\mathrm{Na}$ experiência de ser mãe de uma criança com câncer, a mãe procura Dar tudo de si mesma, ou seja, a mãe sabe que sempre foi mãe daquela criança, fazendo seu papel, cuidando e protegendo o filho. Mas agora se sente mais mãe, pois o seu cuidado, a sua capacidade e 
necessidade de proteção, bem como sua atenção para a criança se tornaram ainda maiores. A mãe sente que é capaz de superar qualquer obstáculo que aparecer à sua frente e faria tudo de novo para o filho se fosse preciso. A sua capacidade de se doar aumenta, e ultrapassa todos os limites na luta pela vida do filho, fazendo tudo que faz para a criança não por uma obrigação de mãe, mas por amor. Para isso, ela busca ser mais compreensiva, paciente e aprende a ser ainda mais atenciosa com a criança. A mãe sabe que é necessário levar o tratamento a sério, porém, mais do que ter um cuidado especial, ela percebe que a forma como cuida é diferente e existe uma preocupação maior de não errar, de não deixar o filho sofrer ou ao menos, de aliviar este sofrimento.

Então, sinceramente, eu fazia mais eu fazia por amor a ele, né? Por amor mesmo, não fazia por fazer, por uma obrigação de mãe ter que fazer, que é o que eu te falei quando eu tinha antes ele sem o tratamento, eu fazia por uma obrigação de mãe, que eu achava que era minha obrigação e pronto. Hoje não, através do tratamento eu fazia de coração mesmo, do fundo do coração, porque eu sabia que meu filho precisava muito mais de mim, muito mais dessa mãe. (Mãe 3)

Eu acho que o amor prevalece tudo, né? O amor ele é assim, de uma forma mãe pra filho, indiscutível. Eu acho que toda mãe deve amar seu filho, com problema ou não... Ela tem que ser a mãe que eu acho que em todas as horas ele deve contar, não só nas horas alegres, mas nas horas difíceis também, porque não? Eu acho que até aí tem que, como eu falei, bato muito nessa tecla, tem que doar muito mais do que a gente pode. Eu acho que o amor acima de tudo fortalece, ele é a base. Pra tudo que vai acontecer com a criança, o amor é a base de tudo. Se não tiver essa base com amor, não vale tudo aquilo que você faz. (Mãe 3)

Se sentir capaz? É você dar sua vida, é você doar aquilo que você mais tem de bom, que é seu coração, seu amor, pra uma criança. Se sentir capaz é você, assim se tornar pra ele como um super herói, ele te reconhecer como um super herói, uma pessoa que todo tempo esteve ao lado, que eu nunca abandonei, nunca vou abandonar, que ele pode contar sempre com essa mãe, que sempre eu vou estar do lado dele. Isso é sentir capaz. (Mãe 3)

Então, como mãe eu vejo assim, que foi uma experiência muito... vamos dizer, até que boa em partes, de tudo isso eu vejo que pode tirar alguma qualidade, porque aí sim que está o 
prestar do seu filho, porque como mãe a gente sempre está ao lado do filho, mas nessa hora você está mais, você duplica, porque você acaba vendo o outro lado da criança que você ama, que você gerou, que você mais que você tem que dar uma atenção maior ainda por ser um caso especial, por você saber que está tratando de uma doença que é séria, não é uma doença qualquer.

Então aí vem um papel de mãe até mais prestativo, você quer, assim, como vou dizer, você quer que seu filho sare de qualquer jeito. Tem uma esperança que há uma salvação pra ele.

(Mãe 3)

O amor eu acho que foi o essencial desse tratamento, foi a base mesmo de tudo, foi esse amor tão grande que eu tenho pelo meu filho, que pra mim é a coisa mais maravilhosa na minha vida! E que eu faria tudo de novo! Faria, se fosse possível, e procuraria corrigir talvez alguns erros que eu tive para fazer sempre melhor e melhor... Sabe, que não há preço, não há nada assim, que pague você ver seu filho bem, curado e ele sorrindo de braços abertos pra você. Eu acho que não tem o que pague isso... Não tem... (Mãe 3)

Tudo que você faz pela criança, você se sente mais mãe. Ainda mais que perdeu o pai, então você tem que fazer o possível e o impossível por ela. Não deixar ela sofrer, foi isso que o pai pediu antes de morrer. Então, é isso que eu faço. (Mãe 4)

$\mathrm{Na}$ experiência de ser mãe de uma criança com câncer vivenciando um tempo de luta pela vida do filho, a mãe se sente mais sensível ao que acontece e ao que está ao seu redor. Neste sentido, para a mãe estar com a criança é considerada por ela uma benção. Vivenciar a experiência em plenitude é procurar conhecer mais ainda sobre o filho e quer compensar todo tempo que não passou com ele antes. Ela valoriza cada atitude, cada momento com a criança, percebendo-se muito mais sensível neste tempo de luta. O seu amor pela criança parece aumentar e ser mais forte do que antes da doença e é este amor somado ao desejo de não querer que seu tempo com a criança se acabe que a fazem agir e se preencher na presença junto ao filho.

Antes eu me achava uma mãe, como eu disse, uma que cobrava, uma mãe que tinha amor, sempre teve amor! Mas uma mãe que não transparecia esse amor. Que deixava escondido, deixava oculto... E após o tratamento, eu mesma me descobri, redescobri essa mãe que eu 
sou, sempre fui essa mãe! Só que precisou acontecer tudo isso pra mim me reconhecer. Pra mim dar valor no meu filho, pra eu entender tudo que eu não entendia! Por que eu me entregar tanto, por que eu ser paciente, por que eu ficar feliz com um simples gesto dele, entendeu? Então essa mãe $S$. depois do tratamento é uma mãe que eu acho que todas as mães são, mas que a gente tem que descobrir, tem que ir lá no fundo buscar essa mãe que existe dentro da gente. (Mãe 3)

Então, a parte de bom disso tudo é que você valoriza realmente o ser humano, valoriza a vida. Você aprende a dar valor em coisas que você antes não dava... Em coisas pequenininhas... Um sorriso de uma criança, isso te enche de uma imensidão de alegria que às vezes a gente não dá valor, quando você tem uma vida normal... Você vê que aquele sorriso é de sinceridade, é um sorriso do fundo do coração, que é uma coisa verdadeira que passa pra você! Então eu via, assim, meu filho dando um sorriso pra mim, aquilo me preenchia de uma forma que eu falava: "Pronto, já compensou tudo que eu passei até agora, só esse sorriso, só esse ânimo dele já me preencheu tudo que eu queria"! Então essa era a parte boa... é a parte boa... (Mãe 3)

E tudo nessa vida, a gente tem que tirar, sempre tem o lado bom. Aí eu comecei a analisar, o que foi o lado bom disso aí, foram essas coisas que eu te contei. De eu perceber o amor que a gente tem, ele aumenta, a atenção, a dedicação, que você tem, aumenta. E o valor à vida, de tudo aumenta, porque é aquilo que eu te falei, são mínimos detalhes que você dá valor. Se você parar pra pensar, antigamente eu não ligava pra isso, mas agora eu ligo, e é muito bonito. É... É muito bonito. Toca lá no fundo do coração da gente, entendeu? Não vou dizer que a gente era insensível, né, mas agora a gente está muito mais sensível! Com certeza! Agora a gente dá muito mais atenção para as coisas que passavam despercebidas. E vim pensando nisso tudo, todo dia, e fui descobrir essas mudanças. A gente tem que ver e pensar no porquê de a gente estar aqui. Por que será, né? Tem alguma coisa do porquê da gente estar aqui, passando por isso tudo. O que a gente tem que tirar de proveito disso tudo. E eu acho que o proveito é esse. É a atenção, o carinho, tanto a ela quanto ao próximo, sabe, esse amor a vida, essa esperança que a gente sempre tem que ter, se agarra, pra viver, pra lutar pela vida deles. Então eu acho que isso tudo a gente vai aprendendo aqui... (Mãe 7) 


\subsection{Identificando os momentos reveladores}

A narrativa biográfica conta uma série de eventos em uma seqüência temporal e causal que são significantes para o narrador, e como uma história da vida esta pessoa, tem um começo, um meio e um fim. Na biografia, alguns momentos são relembrados de forma intensa, que acontecem em situações problemáticas e interacionais. Esses momentos são os momentos reveladores na experiência daquela pessoa, a partir dos quais acontece um redirecionamento de suas vidas. São momentos regados de sentimentos intensos, que ocasionam profundos efeitos, aos quais são atribuídos significados e que jamais serão esquecidos, chamados momentos reveladores, ou epifanias. Ao buscarmos compreender a experiência de ser mãe de uma criança com câncer, estudamos a ocorrência do evento câncer do filho na sua biografia, que nos remetem a uma parte de sua vida. Percebemos que existe uma interligação entre a parentalidade, ou seja, entre o fazer o papel de mãe e a temporalidade, na qual o tempo se manifesta enquanto uma das essências na construção deste papel. A temporalidade está presente na ameaça, representada pela doença, ao seu tempo com a criança; nas tomadas de decisão e reorganização da mãe considerando o próprio tempo da doença e da criança; no tempo em que o foco da sua vida é lutar pela vida do filho, cumprindo com um papel que ela acredita ser dela enquanto mãe. As entrevistas revelam as vivências da mãe e, permeando a experiência enquanto momentos reveladores que trazem um redirecionamento na vida, foi possível identificar epifanias, que serão descritas a seguir.

\section{Perceber que seu tempo com a criança está ameaçado}

Este foi o primeiro momento revelador na experiência de ser mãe de uma criança com câncer. Ao receber o diagnóstico de câncer do filho, a mãe percebe que não somente a vida da criança está ameaçada pela doença, mas que o seu tempo como mãe desta criança também está sob perigo. 
Neste momento, a mãe percebe que todos os seus planos, sonhos e expectativas para o futuro do filho podem não se concretizar. Ela vive um tempo de incertezas com relação ao futuro, de temor e ansiedade pela falta de controle que se manifestam na situação de doença.

Primeiramente, há uma negação do que está acontecendo, uma rejeição da idéia de que seu filho tem câncer. É uma situação difícil, permeada pela angústia e pelo medo de não saber o que está para acontecer com sua criança. Apesar de não conhecer a doença, a mãe sabe que ela se caracteriza pelo prenúncio de que algum mal pode acontecer; em outras palavras, a doença se revela como algo que pode colocar a vida do seu filho em risco.

É neste momento revelador que a mãe percebe que o seu tempo com a criança está sob ameaça, a partir do qual que se desencadeiam todas as tomadas de decisão e uma série de ações da mãe a fim de que este tempo não se acabe. Mediante essa ameaça, ela não pode esperar, mas precisa agir e fazer escolhas acerca da sua vida, da vida do seu filho e da vida de sua família.

\section{Decidir que este é o tempo da crianca}

Este momento revelador parece ser, na experiência de ser mãe de uma criança com câncer, o elo entre as duas dimensões da experiência, ou seja, entre VIVER O TEMPO DA DOENÇA e VIVER A LUTA PELA VIDA

\section{DA CRIANÇA.}

Até então a mãe exercia o seu papel nos diversos contextos da sua vida, ou seja, além do papel de mãe (da criança agora doente e de outros filhos) ela também exercia o papel de esposa, de filha, de trabalhadora. Ao perceber que a vida do seu filho está sob ameaça, a mãe se depara com uma situação na qual é fundamental estabelecer uma prioridade para sua vida. Ou seja, a prioridade que naquele tempo que está vivendo será o foco de suas preocupações e em torno da qual todas as suas decisões serão tomadas. É o centro no qual irá canalizar as suas energias, que vai 
determinar qual caminho escolher. Assim, este momento revelador é o momento de decidir que a criança será a prioridade. Decidir que este é o tempo da criança é decidir que ela será o que há de mais importante na sua vida e na vida da sua família, para que todos se preparem e não se percam para o tempo difícil que está por vir.

\section{Lutar pela crianca movida por amor}

A vida da mãe e de cada membro da família, então, passa a organizar-se em torno das necessidades da criança que está doente, e através do diálogo entre eles e das decisões que permeiam a experiência de vivenciaram o câncer da criança, a mãe se percebe vivenciando uma luta. É ela a pessoa que, nessa família, vai assumir a responsabilidade pela vida da criança, acompanhando-a durante todo tratamento. Caracteriza-se na experiência como terceiro momento revelador, pois a mãe acredita que lutar pela vida da criança junto dela é o seu dever como mãe. Isso não significa que os outros membros da família não estão presentes na batalha, pelo contrário. Eles são elementos fundamentais neste tempo de luta, promovendo suporte e fortalecendo a unidade familiar. Mas dentre eles, a mãe é a pessoa que assume o comando. Ela está na linha de frente, o que significa não somente estar perto do filho. É mais que isso: é assumir a luta junto dele, movida pelo seu amor de mãe, como se esta luta também fosse sua, vivenciando a experiência em toda sua plenitude.

Este é um tempo de sacrifício, em que a mãe busca fazer tudo o que puder fazer e estiver ao seu alcance para manter a criança o mais longe possível do perigo que a doença representa; é um tempo de ser o suporte para o filho, preparando-o para a batalha contra o câncer; é um tempo de ser forte e de fortalecer a criança e a família, de cuidar e ser cuidada. 
A partir do momento que a mãe recebe a notícia de que seu filho tem câncer, sua vida muda para sempre. As experiências vivenciadas no tempo da doença e no tempo de lutar pela vida da criança jamais serão apagadas de sua memória. O tempo de temor, de incertezas, da sensação de impotência, de difíceis decisões, assim como o tempo de confiar que o tempo da doença terminará, tendo esperança de viver um tempo futuro longe da doença, têm o poder de gerar transformações na sua vida; são marcas profundas na vida da mãe que vivencia a experiência de ser mãe de uma criança com câncer.

Esta experiência, ao ser revelada, nos permitiu identificar as três epifanias descritas, momentos que se sobressaem com relação aos demais e que permeiam as dimensões do ser mãe na situação do câncer do filho. $A$ partir destes momentos, se revelam importantes alterações no rumo da experiência e transformações na sua vida como mãe.

Assim, a mãe vai construindo seu papel de mãe de uma criança com câncer, evidenciado por um conjunto de comportamentos que se expressam nas interações consigo mesma, com a criança e com todos os elementos envolvidos no processo de tratamento e na experiência de doença. Esses comportamentos têm como elemento central as ações mediadoras da mãe motivadas pela preservação da vida da criança que está ameaçada pela doença, a prioridade neste momento da sua vida.

A forma como esses momentos reveladores se expressam na experiência de ser mãe de uma criança com câncer está representada no diagrama 7. 


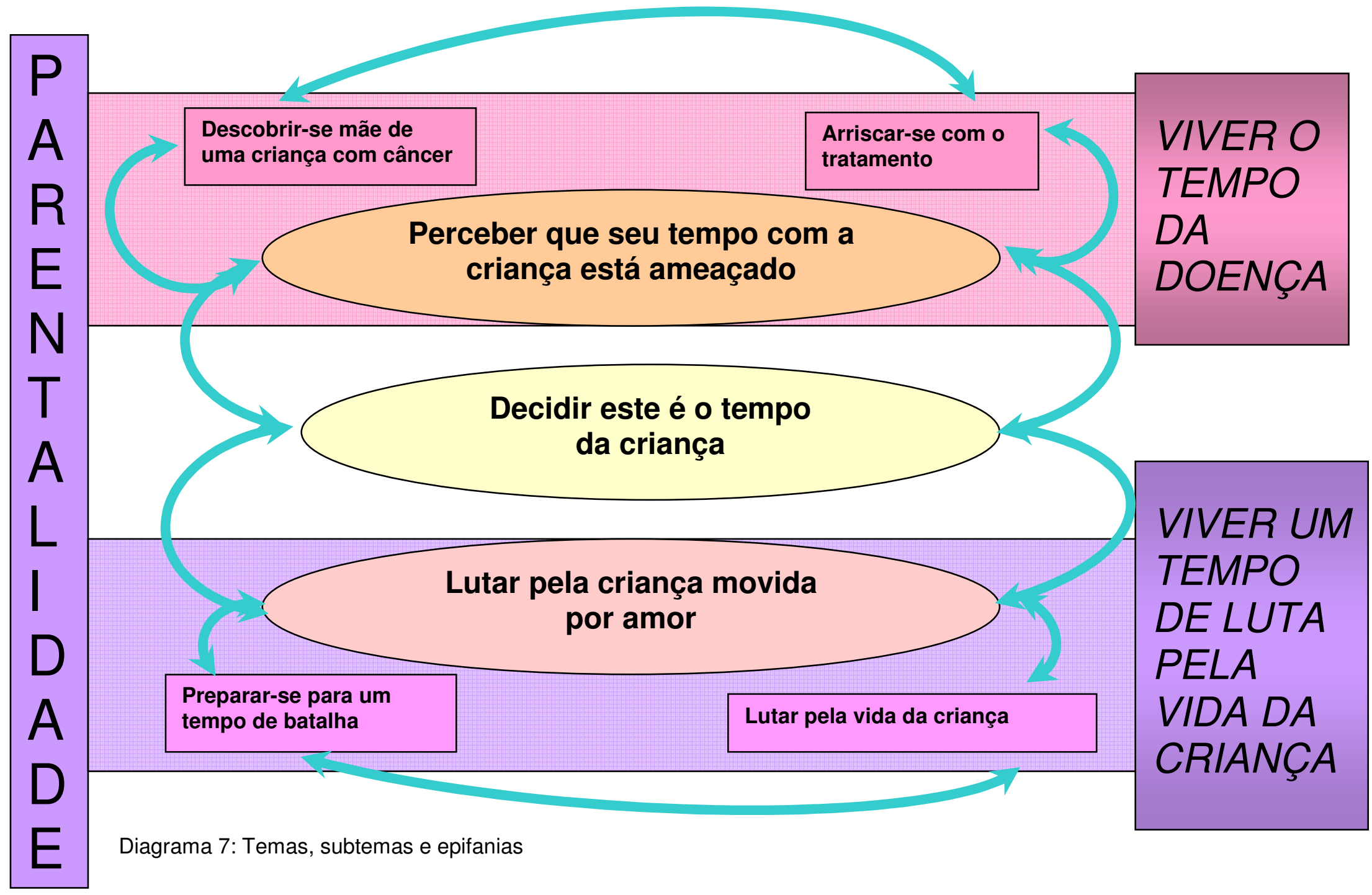


5. Discussão dos Resultados 


\subsection{Discutindo as evidências da experiência de ser mãe de uma criança com câncer}

A parentalidade foi a âncora na busca da compreensão de ser mãe de uma criança com câncer. Partimos do pressuposto de que "Não nascemos pais, tornamo-nos pais". Ou seja, a parentalidade se constrói a partir de ingredientes que podem ser coletivos, como a sociedade e que mudam com o tempo, ou privados, que pertencem a cada um dos pais enquanto pessoas (Moro, 2004).

Ao buscarmos a compreensão da experiência de ser mãe na experiência de ter um filho com câncer, considerando que ser mãe é fazer o papel de mãe, percebemos o tempo como parte desta experiência. Talvez, mais do que isso: o tempo se expressa como uma das essências da parentalidade. A temporalidade se inter-relaciona com a parentalidade na situação do câncer do filho, e ambos, o tempo e o papel da mãe, vão adquirindo um significado neste tempo de transição entre ser mãe de uma criança que ela conhecia como uma criança saudável para ser mãe de uma criança que vivencia o câncer. Assim, viver a experiência de ser mãe de uma criança com câncer é também viver um tempo de transição, no qual a interrelação entre 0 tempo e a parentalidade se expressa nos comportamentos da mãe, na tomada de decisão, na construção do seu papel de mãe e no significado que ela dá a doença e do próprio ser mãe.

A transição na vida das pessoas pode ser planejada ou acontecer inesperadamente. As transições da vida podem ser diversas e têm sido descritas como os caminhos pelos quais as pessoas enfrentam mudanças (Liddle et al, 2004). A experiência de viver o diagnóstico de câncer do filho é uma experiência inesperada e não planejada, assim como o papel de mãe, que não é fixo e que precisa ser revisto, construindo-se um novo papel em função do inesperado. Durante a experiência de transição na sua trajetória, a mãe vivencia dois tempos: o tempo da doença, no qual é revelado o olhar para si mesma, refletindo sobre a sua situação como mãe mediante a doença que ameaça a vida do filho e, conseqüentemente, o seu tempo como 
mãe dessa criança; e o tempo de lutar pela vida da criança, no qual as dimensões da parentalidade são evidenciadas nos comportamentos da mãe ao fazer o seu papel.

A experiência de transição pode acontecer em decorrência de mudanças na situação de saúde e doença nos indivíduos, sendo considerada complexa e multidimensional, na qual algumas propriedades podem ser identificadas: a consciência, o compromisso, as mudanças, o tempo e os eventos críticos (Meleis et al, 2000). Cada uma dessas propriedades podem ser identificadas na experiência de ser mãe de uma criança com câncer, algumas de forma mais discreta, outras de uma forma bastante evidente.

A consciência está relacionada com a percepção, conhecimento e reconhecimento da experiência de transição. Ou seja, é ter a consciência de que mudanças estão acontecendo nas suas vidas (Meleis et al, 2000). No nosso estudo, identificamos que a mãe, ao descobrir-se mãe de uma criança com câncer, percebe que sua vida não é mais a mesma. O próprio tempo de viver o diagnóstico de câncer do filho envolve uma mudança inesperada, algo que ela nunca imaginou acontecer com sua família. A partir deste evento, a mãe reconhece que sua trajetória foi alterada pela doença e pelas suas demandas, ou seja, pelas mudanças que acontecem na sua vida e na vida de sua família.

A segunda propriedade mencionada como parte da experiência de transição é o compromisso, definido como a intensidade com que a pessoa demonstra envolvimento no processo inerente a transição (Meleis et al, 2000). Percebemos, na experiência de ser mãe de uma criança com câncer, que o engajamento e o compromisso da mãe se expressam nas suas ações ao assumir a responsabilidade pela vida do filho e cumprir com o dever que ela acredita ser seu como mãe daquela criança. O compromisso da mãe na situação de câncer do filho é tamanho que ela se coloca como parte desta luta, ou seja, como se essa luta fosse dela também, movida pelo amor que tem pelo filho. 
A mudança é considerada uma propriedade essencial da transição, já que toda transição envolve mudanças. Para que o processo de transição seja compreendido completamente, é necessário descobrir e descrever os efeitos e significados que estão envolvidos nas mudanças. A temporalidade é uma das dimensões da mudança que devem ser exploradas na experiência de transição (Meleis et al, 2000). O tempo se manifesta em diversas circunstâncias. A primeira delas, que está intimamente ligada às mudanças que a mãe tem consciência que estão acontecendo na sua vida é aceitação da idéia de ser mãe de uma criança com câncer. Para isso, o tempo é necessário para que ela possa admitir que não somente a doença faz parte de sua criança e de sua família, mas admitir que sua vida mudou.

Como mencionado, a temporalidade é uma das dimensões a serem exploradas na experiência da mudança, mas também é uma das propriedades da experiência de transição. Em experiências de doença, a transição não é sempre seguida de uma trajetória cronológica, mas sim, caracterizada como o fluxo e movimento ao longo do tempo. A transição é a extensão do tempo que se inicia com os primeiros sinais de uma mudança, flui através de um período de instabilidade, confusão e angústia e termina com um novo começo ou um período de estabilidade (Meleis et al, 2000). A experiência de ser mãe de uma criança com câncer é uma ruptura na sua trajetória, na sua biografia, no qual ela percebe sua vida alterada pela ocorrência da doença. Inicia-se com as primeiras manifestações da doença, geralmente percebidas pela própria mãe. O tempo de vivenciar o diagnóstico do filho e se descobrir mãe de uma criança com câncer é permeado pela instabilidade de uma vida invadida pela doença e desestruturação na dinâmica familiar. Com o tempo, a mãe decide se arriscar com o tratamento compreendendo que este é o tempo da criança, o tempo de lutar pela vida da criança e tudo que está ao seu alcance é feito para afastar a ameaça de morte representada pela doença. Uma das expressões do tempo que percebemos na experiência da mãe da criança com câncer está relacionada com a necessidade de estar à frente do tempo da doença que avança. Ou seja, o tempo dela agir assumindo as responsabilidades do tratamento, que 
precisa ser mais rápido do que o tempo de evolução da doença a fim de afastar ao máximo a possibilidade de perda daquela criança.

Os eventos críticos podem ser associados a eventos marcantes e difíceis, como o diagnóstico de uma doença e os intensos efeitos do tratamento. São períodos de intensa vulnerabilidade e nos quais as pessoas encontram dificuldades com o auto-cuidado e em cuidar. Também estão frequentemente relacionados com o aumento da consciência de mudança ou com o aumento do compromisso em lidar com a experiência de transição (Meleis et al, 2000). A mãe, mesmo nos períodos de dificuldade e nos momentos mais críticos do tratamento, prossegue sua trajetória na luta pela vida do filho. Isso faz parte do seu compromisso e do seu dever como mãe. Ela tem consciência das mudanças decorrentes da doença, mas também do papel que acredita ser seu enquanto mãe.

Como percebemos, a temporalidade é um importante elemento na experiência de transição e, em nosso estudo, na construção da parentalidade. Podemos assim considerar a temporalidade como um dos importantes elementos da parentalidade.

A temporalidade é abordada em diversos estudos na área da saúde, também considerada como a experiência do tempo vivida pela família, cada dia como ele acontece e sendo incapazes de fazer planos em longo prazo. Ou seja, eles vivem dia após dia, sendo o tempo pontuado pelos eventos e situações relacionados ao cuidado da doença. A temporalidade é considerada como uma dimensão chave no estudo de Jeon e Madjar (1998), acerca da experiência da família de cuidar de um filho ou pai afetado pela doença mental crônica. A temporalidade pontua na experiência de doença um senso de perda pelo passado que não pode ser recapturado, e presente que é diferente e apreensivo e o futuro que reúne mais medos do que sonhos.

Neste sentido, pensando no tempo passado, presente e futuro, a temporalidade também se expressa em nosso estudo, na percepção da mãe pela necessidade de viver o presente. Ser mãe é viver cada dia, é ter como o foco da sua atenção o hoje. Na verdade, a mãe sabe que o passado 
existiu e deixou marcas profundas na sua vida e na vida de sua família, mas sendo o futuro uma incerteza, o seu foco para agir é o hoje. Ao decidir arriscar-se com o tratamento, o que a mãe tem em mãos é o agora, é o que ela pode fazer agora pelo seu filho. Apesar disso, de viver o tempo presente, ao viver o tempo da doença a mãe também acreditar que este tempo vai acabar. É colocar a esperança do presente se projetando no futuro de um outro tempo, longe do sofrimento da doença. Em outras palavras, hoje é o tempo de fazer o seu papel de mãe da melhor forma possível, de forma a cumprir com as demandas do tratamento e da criança. Mas para isso, para desenvolver o seu papel, é preciso ter esperança que aquela experiência vai ter um fim; é como se a esperança do futuro fosse o alimento para a mãe fazer o seu papel hoje.

Ray (2002) considera que os aspectos típicos da parentalidade nas diversas situações da vida comparado na situação de doença crônica do filho são maiores neste segundo contexto, tanto no que se refere a intensidade quanto na duração - que às vezes, considerando a doença crônica, acontece pela vida toda. Na situação do câncer infantil, a intensidade da parentalidade poderia estar relacionada ao significado que a mãe atribui a doença do filho, ou seja, de uma doença ameaçadora a sua vida. Além disso, como é revelado nas narrativas, é uma experiência que jamais se esquece, que sempre acompanhará a vida dessas mães, deixando marcas profundas na biografia de quem a vivencia.

Em estudo acerca de como mães de adolescentes experienciam a gravidez na adolescência de seus filhos e a parentalidade, Dallas (2004) define que a transição nesta circunstância é uma sequência de eventos que vão tomando seu lugar ao longo dos anos, começando com um marco que prepara os futuros pais e mães e suas famílias na passagem de um novo status social. Na experiência de ser mãe de uma criança com câncer, descobrir que seu tempo com a criança está ameaçado marca o início de uma trajetória no qual a mãe constrói o seu papel de mãe, vivendo aquele tempo como o tempo da criança e cumprindo com o seu dever de mãe. A partir daí, a mãe passa a ser agora mãe de uma criança com câncer, não 
somente no que se refere a um novo status social, mas um novo papel na sua biografia e na vida de sua criança.

Com o objetivo compreender o fenômeno da maternalidade (em inglês, mothering) experienciado por mulheres que foram as principais cuidadoras de seus filhos adultos que morreram pela AIDS (Nelms, 2002), algumas dimensões foram identificadas e uma delas, relacionada ao tempo vivido. As mães expressam a temporalidade relacionada a religião ou espiritualidade, descrevendo seu tempo com o filho como "um presente de Deus". A essência da maternalidade se expressou nos fatores contextuais como o parentesco biológico, a doença ameaçadora de vida, no compromisso da mãe de cuidar de seus filhos, e da reconexão do cuidado dado aos filhos na fase da infância. Para essas mães, cuidar de seus filhos foi o que elas tinham que fazer enquanto mães, ouvindo e respondendo ao chamado da consciência de fazer o que elas acreditavam que cabia a elas mesmas como mãe, mulher e ser humano.

Em nosso estudo, esse chamado de consciência é vivenciado pela mãe ao lutar pela vida da criança. O que cabe a ela como mãe está presente nas suas ações, no seu papel de mãe desempenhado pelo significado que dá ao ser mãe de uma criança com câncer. Poderíamos dizer que é este chamado da consciência que faz com que a mãe, ao perceber que a vida do seu filho e seu tempo como mãe desta criança está ameaçado, bem como que este é o tempo da criança, cumpra com o seu papel e seu dever como mãe vivenciando a luta junto ao filho como se fosse sua.

Ao desempenhar seu papel de mãe, podemos dizer que o tempo também se faz presente em todas as dimensões na experiência de lutar pela vida da criança vivenciada pela mãe. É evidenciado principalmente nas tomadas de decisão da mãe tendo como objetivo permanecer disponível a todo tempo para estar ao lado do filho doente. A partir desta necessidade e responsabilidade que assume para si, ela reorganiza-se junto à família para vivenciar a luta contar a doença do filho.

Em outro estudo acerca do papel da maternalidade com mães de crianças que dependem de nutrição parenteral (Judson, 2004), o cuidado 
protetor permeia todas as ações da mãe com a criança, e para proporcionálo, a mãe sente a necessidade de ter controle acerca da situação. Proteger a criança envolve também uma vigilância intensa, e o nível do cuidado protetor é mediado pelo tempo, mas nunca diminuído como uma tarefa. Neste estudo, a mãe, ao lutar pela vida da criança desempenhando seu papel de mãe, busca a todo o momento proteger o filho de forma a afastá-lo de qualquer agravo à sua saúde e da possibilidade da perda. Proteger o filho é uma estratégia para que o seu tempo como mãe não se acabe.

Como já mencionamos e percebemos nas evidências deste estudo através das narrativas, a mãe é a principal fonte de suporte para a criança doente e para a família. É a mãe quem se revela nesta posição ao decidir que a criança é a prioridade e assumir a luta pela vida da criança. Gostaríamos de mencionar alguns estudos e considerações de autores que não tiveram como objetivo compreender a experiência de ser mãe de uma criança com câncer e não tiveram como foco o papel da mãe, mas que em suas evidências, mostraram a importância da mãe como suporte para a criança no tempo de luta pela sua vida.

O papel de mãe na família é um dos papéis que se modifica logo no início da doença, já que este evento exige que alguém permaneça ao lado da criança, dedicando-se integralmente ao seu cuidado e observação. Assim, a mãe opta por deixar de trabalhar para assumir o cuidado à sua criança. Mesmo quando a mãe é a provedora das finanças da família, ela reorganiza-se de forma a conciliar o cuidado ao filho às suas demais obrigações. O cuidado ao filho é a prioridade para a família, que se reorganiza de forma que cada membro tenha uma função na situação de doença (Damião e Angelo, 2004). Compartilhamos essas considerações, quando a mãe, na experiência de câncer do filho, decide que a criança é a prioridade na sua vida e na vida de sua família. Assim, a mãe se prepara para um tempo de batalha, fazendo escolhas e se reorganizando em função das demandas da doença. A mãe assume a luta pela vida da criança, vivenciando a luta pela vida do filho, protegendo e sendo suporte para ele. 
As evidências reveladas por Ribeiro e Angelo (2005) mostraram o movimento da mãe durante a hospitalização no sentido de proteger o filho, permanecendo ao seu lado, procurando compreender e responder às suas necessidades físicas e emocionais, cuidando, apoiando, informando, confortando, acariciando e tentando facilitar as interações e mantendo o vínculo com a família.

Em estudo sobre a experiência da mãe acompanhando seu filho durante a hospitalização, Oliveira e Angelo (2000), mostraram que a mãe enfrenta tudo para cumprir o que acredita ser o seu dever de mãe, assumindo a missão de protegê-lo, de poupá-lo de um sofrimento ainda maior, o que exige que ela se afaste dos outros filhos e da família. A mãe, segundo as autoras, sofre junto com o filho, vivenciando a dor de não poder fazer nada para impedir seu sofrimento. Nossas evidências mostram que na experiência de ser mãe de uma criança com câncer, a mãe assume lutar pela vida da criança, protegendo o filho através de ações que visam ter um cuidado especial, observando detalhes, buscando de alguma forma aliviar seu sofrimento e permitindo que a criança viva seu tempo de criança. Além disso, ao lutar pela vida da criança, a mãe procura ser suporte para a criança através de comportamentos direcionados a ela com o objetivo de revelar a doença para a criança, preparar a criança para a batalha, mas também contar com a ajuda da criança para que possa desenvolver o seu papel.

Podemos dizer, então, que ser mãe de uma criança com câncer é vivenciar uma experiência mediada pela construção de um papel, ou seja, de tornar-se mãe, construindo a parentalidade, e que esta construção é permeada pelo seu dever como mãe e pelo tempo como mãe que está ameaçado pelo significado que ela atribui à doença. As dimensões do ser mãe de uma criança com câncer ultrapassam as dimensões do cuidado, e se expressam em um conjunto de comportamentos e de ações, ou seja, de seu papel como mãe, mediadas pelo tempo e pela necessidade de afastar a possibilidade de perder aquela criança. 
6. Considerações finais 


\subsection{Tecendo algumas considerações acerca da experiência}

As narrativas das mães entrevistadas revelaram que o papel da mãe no vivenciando o câncer do filho é construído num processo articulado, que conjuga a interação entre o tempo da doença e o tempo de viver a luta pela vida da criança. Além disso, é evidenciado na experiência através dos momentos reveladores, que ocasionam um redirecionamento na trajetória dessas mulheres.

A conversa que a mãe estabelece consigo mesma ao viver o tempo da doença começa pela aceitação de que o filho tem câncer e, ao arriscar-se com o tratamento, é continuamente permeado pelas incertezas inerentes à doença e à necessidade de afastar a ameaça de morte da criança.

A construção do papel da mãe evidencia um conjunto de comportamentos que se expressam nas interações consigo mesma, com a criança e com todos os elementos envolvidos na experiência da doença, tendo em sua essência a luta, movida pelo amor à criança, através das ações mediadoras da mãe motivadas pela preservação da vida do filho para que seu tempo como mãe daquela criança, ameaçado pela doença, não se acabe.

A partir desse olhar, à luz dos pressupostos do Interacionismo Simbólico, compreendemos que o papel da mãe é um papel multidimensional e que se expressa nos comportamentos da mãe com o objetivo de afastar a idéia de morte do seu filho. Os significados atribuídos por ela e a sua perspectiva mediante a doença do filho se expressam nas ações, reflexões, reorganizações, decisões e responsabilidades que a mãe assume mediante o filho doente.

Ao vivenciar o tempo da doença, percebemos claramente o papel do self, ou seja, o meio interno que guia os nossos atos e que permite que o indivíduo volte para si mesmo. É neste tempo de doença que a mãe estabelece uma conversa consigo mesma, um olhar para si e se percebe mãe de uma criança com câncer. Ou seja, sendo o self um objeto social e que emerge da interação social, sendo definido e redefinido a partir destas 
interações, as interações vivenciadas pela experiência de doença permitem que não somente ela perceba a sua criança como uma criança com câncer, mas também que ela é mãe de uma criança com câncer. Assim, a mãe é capaz de julgar a si mesma como mãe de uma criança com câncer, estabelecendo uma identidade.

$\mathrm{Na}$ construção do seu papel de mãe vivenciando o câncer de sua criança, a mãe atribui um significado à doença do filho mediante o diagnóstico, de acordo com as suas interações até então. A medida que vai lutando, interage com outras pessoas (profissionais de saúde, outras famílias de crianças com câncer), com o ambiente (o hospital no qual realiza o tratamento oncológico) e consigo mesma, ou seja, com seu próprio self (quando aceita a idéia de ser mãe de uma criança com câncer, e arriscandose com o tratamento, tendo a criança como o que há de mais importante). Assim, a partir destas interações, interpreta-as e redefine o significado também para a sua experiência, agindo e comportando-se tendo como ponto de partida a sua decisão de assumir a luta pela vida da criança. Ou seja, a construção do seu papel de mãe envolve um processo formativo no qual os significados são utilizados e revisados como instrumentos que guiam as suas ações como mãe vivenciando o câncer do filho.

Percebemos neste tempo de lutar pela vida da criança, à luz do Interacionismo Simbólico, o papel da mente. Sendo a mente a atividade, toda ação que o indivíduo faz através e em direção a si e todo pensamento e toda manipulação ativa de símbolos na conversação consigo mesmo e com o seu self, a mãe é capaz, através da atuação da mente, de cumprir com o seu dever de mãe. Considerando que a mente tem habilidade de controlar ações e de resolver problemas, a mãe, mediante a ameaça representada pela doença, muda a sua relação com o ambiente construindo um novo papel mediante as demandas do câncer e plenamente consciente do universo da doença.

Através das ações da mãe reveladas na sua biografia e mediadas pela consciência de que o seu tempo como mãe da criança está ameaçado, percebemos, na abordagem interacionista, a ação humana. As ações da 
mãe são motivadas pelo objetivo de lutar pela vida da criança sempre e em qualquer circunstância, envolvendo todas as suas decisões. A partir do momento que a mãe define sua situação como mãe de uma criança com câncer, em interação com o self e com o outro, iniciam-se suas ações, ou seja, ela cumpre com o seu papel.

Assim, considerando a mãe da criança com câncer com uma pessoa que interage consigo mesma, com o filho, com a família e com todas as pessoas e eventos que fazem parte da experiência da doença, foi possível compreender como a parentalidade se compõe na história de ser mãe de uma criança com câncer e como a temporalidade emerge nesta experiência. Ou seja, a perspectiva interacionista possibilitou compreender como a mãe constrói o seu papel de mãe de uma criança com câncer através um processo dinâmico. Este processo envolve definir situações de acordo com os significados atribuídos e alterados nas interações sociais, no processo interno de conversa com o seu próprio self e nas ações da mãe ao agir e cumprir com o seu papel de mãe.

Considerando a escassez de evidências na literatura e estudos que tem como foco a busca da compreensão do multidimensional papel da mãe e da construção da parentalidade na experiência de tornar-se e ser mãe de uma criança com câncer, acreditamos que este estudo poderá contribuir para um a construção de um novo paradigma no pensar sobre esta experiência. Os dados mostram como a mãe, mesmo mediante todo sofrimento ocasionada pela situação de doença do filho, prossegue sua jornada como mãe e assume a luta contra a doença do filho junto da criança. As evidências mostram como a parentalidade e a temporalidade se interrelacionam nesta experiência de transição, no qual a mãe vivencia um tempo como mãe ameaçado pela doença, respeita o tempo da criança, e cumpre com o seu dever de mãe.

Concordamos com Wright (2005) quando menciona que é um privilégio para os profissionais de saúde, dentre eles, os profissionais da enfermagem, poderem ajudar pessoas que vivenciam 0 sofrimento emocional, físico e espiritual, por estarem vivenciando uma situação de 
doença e que sofrem também para encontrar o significado, a intenção e as ligações da sua vida, modificada pela doença.

"Na aventura de cada família, ela vem ao nosso encontro, às vezes apenas de passagem. Seria muito bom para ela, que tal como naquela estalagem à beira do caminho, encontrasse alguém esperando por ela para poder servi-la, aliviá-la de suas demandas e restabelecer-se, recuperando forças para prosseguir o caminho" (Angelo, 1999). Acreditamos que as evidências deste estudo podem trazer subsídios para uma assistência que vise compreender a experiência de ser mãe da criança com câncer no que se refere ao seu papel, determinado em tantas situações pelo seu tempo como mãe que está ameaçado e pode acabar. A partir desta perspectiva, a assistência de enfermagem poderia ser esta fonte de conforto, suporte e apoio, pensando na mãe da criança com câncer de forma integrada ao seu papel de mãe.

A compreensão da experiência vivenciada pela mãe de uma criança com câncer na construção da parentalidade, pode proporcionar elementos que direcionem mais precisamente as ações de apoio e suporte, suprindo as reais necessidades da mãe e garantindo a plena vivência da experiência pela família na complexa trajetória do câncer infantil. Assim, a partir desta compreensão, a enfermagem pode oferecer suporte e respeitar o tempo para que a mãe possa construir seu papel mediante as demandas da doença e assim, ser mãe de uma criança com câncer de forma a dar significado à sua experiência e desenvolver o papel que considera como seu em direção ao seu filho. Um papel no qual o tempo se faz presente nas suas ações como mãe de uma criança com câncer. 
Tudo tem seu tempo determinado, e há tempo para todo o propósito debaixo do céu; Há tempo de nascer, e tempo de morrer; tempo de plantar e tempo de arrancar o que se plantou;

Tempo de matar, e tempo de curar, tempo de derrubar, e tempo de edificar; Tempo de chorar e tempo de rir;

Tempo de prantear, e tempo de saltar de alegria; Tempo de espalhar pedras, e tempo de ajuntar pedras, tempo de abraçar, e tempo de afastar-se de abraçar; Tempo de buscar, e tempo de perder; Tempo de guardar, e tempo de deixar fora; Tempo de rasgar, e tempo de coser; Tempo de estar calado, e tempo de falar; Tempo de amar, e tempo de aborrecer; Tempo de guerra, e tempo de paz. 
Anexos 
Anexo 1 - aprovação do CEP 


\section{TERMO DE CONSENTIMENTO LIVRE E ESCLARECIDO' ${ }^{1}$}

Meu nome é Patrícia Luciana Moreira, sou enfermeira e aluna do curso de pós-graduação da Escola de Enfermagem da USP e estou realizando um estudo que tem como objetivo compreender a experiência de ser mãe de uma criança com câncer. Para isso, serão realizadas entrevistas com mães de crianças com câncer que aceitem participar do estudo.

A entrevista será realizada em local privado e poderá ser solicitada mais de uma entrevista com um mesmo participante, caso seja necessário. O conteúdo da entrevista será gravado para posterior transcrição e análise dos dados. As fitas, com o conteúdo das entrevistas, permanecerão guardadas com a pesquisadora, e somente a pesquisadora e a orientadora do estudo terão acesso a seu conteúdo.

À participante do estudo serão garantidos: o sigilo das informações, o anonimato, bem como a liberdade para retirar o consentimento a qualquer momento e deixar de participar do estudo, mesmo após ter assinado o termo, sem que isto traga qualquer prejuízo. Após a concessão da entrevista, caso desejar que os dados não sejam mais utilizados, poderá contatar a pesquisadora, com a certeza da devolução da fita e destruição da transcrição. A participante do estudo terá direito a receber informações adicionais sobre o estudo a qualquer momento, mantendo contato com o pesquisador.

Os resultados obtidos com o estudo serão divulgados em eventos e publicações científicas.

Diante do exposto, eu

declaro que fui convenientemente esclarecida sobre o estudo a ser realizado por Patrícia Luciana Moreira e consinto em participar.

A pesquisa terá a duração de um ano. Durante este período, caso necessite de informações adicionais ou decidir pela retirada do consentimento e que os dados não sejam mais utilizados, entrarei em contato com a pesquisadora responsável, Patrícia Luciana Moreira, pelos telefones 4533-4868 ou 3066-7610.

Este documento possui duas vias, uma ficará em posse da entrevistada e a outra será arquivada com a pesquisadora.

São Paulo, de de 2005 .

Assinatura do sujeito de pesquisa ou responsável legal

\footnotetext{
${ }^{1}$ Comitê de Ética em Pesquisa -EEUSP - Fone: (11) 3066-7548
} 


\section{Referências Bibliográficas}


Allen R, Newman SP, Souhami RL. Anxiety and depression in adolescent cancer: findings in patients and parents at the time of diagnosis. Eur $\mathrm{J}$ Cancer. 1997; 33(8):1250-5.

Amazonas MCLA, Braga MGR. Reflexões acerca das novas formas de parentalidade e suas possíveis vicissitudes culturais e subjetivas. Ágora. 2006; 9(2):177-91.

Angelo M, Bousso RS. Fundamentos da Assistência à Família em Saúde. In: Ministério da Saúde (Org.). Manual de Enfermagem. [citado 2005 Abr 19].

São Paulo, Universidade de São Paulo, 2001. Disponível em: http://www.idssaude.org.br/enfermagem.

Angelo M. Com a família em tempos difíceis: uma perspectiva de enfermagem. [tese livre docência]. São Paulo. Escola de Enfermagem da Universidade de São Paulo, 1997.

Angelo M. Abrir-se para a família: superando desafios. Fam Saúde Desenv. 1999; 1(1/2):7-14.

Bessa LCL. Famílias de crianças com câncer. Pediatr Atual. 1997; 10(1/2):11-3.

Bielemann VLM. A família cuidando do ser humano com câncer e sentindo a experiência. Rev Bras Enf. 2003; 56(2):133-7.

Blumer H. Symbolic Interacionism: perspective and method. Englewood Cliffs: Prentience-Hall, 1969.

Björk M, Wiebe T, Hallström I. Striving to survive: families' lived experiences when a child is diagnosed with cancer. J Pediatr Oncol Nurs. 2005; 22(5):265-75.

Boman K, Lindahl A, Björk O. Disease-related distress in parents of children with cancer at various stages after the time of diagnosis. Acta Oncol. 2003; 42(2):137-46. 
Brown KAE, Barbarin OA. Gender differences in parenting a child with cancer. Soc. Work Health Care. 1996; 22(4):53-71.

Catillo E, Catherine CA. Viviendo com el cáncer de un (a) hijo (a). Colomb Méd. 2003; 34:155-63.

Chao CC, Chen SH, Wang CY, Wu YC, Yeh CH. Psychosocial adjustment among pediatric cancer patients and their parents. Psychiatry Clin Neurosci. 2003; 57:75-81.

Charon JM. Symbolic Interacionism. An introduction, on interpretation, an integration. New Jersey: Prentice Hall, 1989.

Clarke JN, Fletcher P. Comunication issues faced by parents who have a child diagnosed with cancer. J Pediatr Oncol Nurs. 2003; 20(4):175-91.

Clarke JN, Fletcher PC, Schneider MA. Mothers' home health care work when their children have cancer. J Pediatr Oncol Nurs. 2005; 22(6):365-73.

Clarke-Steffen L. Reconstructing reality: family strategies for managing childhood cancer. J Pediatr Nurs. 1997; 12(5):278-87.

Costa FT, Teixeira MAP, Gomes WB. Responsividade e exigência: duas escalas para avaliar estilos parentais. Psicol reflex crit. 2000; 13(3):465-73.

Costa JC, Lima RAG. Crianças/adolescentes em quimioterapia ambulatorial: implicações para a enfermagem. Rev Latino-Am Enfermagem 2002; 10(3):321-33.

Crom DB. The experience of South American mothers who have a child being treated for malignancy in the United States. J Pediatr Oncol Nurs. 1995; 12(3):104-12.

Dahlquist LM, Pendley JS. When distraction fails: parental anxiety and children's responses to distraction during cancer procedures. J Pediatr Psychol. 2005; 30(7):623-8. 
Dallas C. Family matters: how mothers of adolescent parents experience adolescent pregnancy and parenting. Public Health Nurs. 2004; 21(4):34753.

Damião EBC, Angelo M. A experiência da família em ter uma criança com doença crônica. In: Dulce Maria Rosa Gualda; Roselena Bazilli Bergamasco. (Org.). Enfermagem, Cultura e o Processo Saúde-Doença. São Paulo: Ícone, 2004, p. 119-34.

Delella LA, Araujo TCCF. Câncer na infância: uma investigação sobre a avaliação da desordem de estresse pós-traumático parental e a experiência da sobrevivência. Psicol Argum. 2002; 20(31):42-8.

Denzin NK. Interpretive Interacionism. California: SAGE Publications, 1989.

Dixon-Woods M, Seale C, Young B, Findlay M, Heney D. Representing childhood cancer: accounts from newspapers and parents. Soc Health IIIn. 2003; 25(2):143-64.

Dixon-Woods M, Findlay M, Young B, Cox H, Heney D. Parents' accounts of obtaining a diagnosis of childhood cancer. The Lancet. 2001; 357:670-4.

Dockerty JD, Williams SM, McGee R, Skegg DCG. Impact of childhood cancer on the mental health of parents. Med Pediatr Oncol. 2000; 35:475-83.

Dupas G, Caliri MHL, Franciosi MC. Percepções de enfermeiras de uma instituição hospitalar sobre a assistência prestada à família e à criança portadora de câncer. Rev Bras Cancerol. 1998; 44(4):327-34.

Dupas G, Oliveira I, Costa TNA. A importância do interacionismo simbólico na prática de enfermagem. Rev Esc Enf USP. 1997; 31(2):219-26.

Dupas G, Angelo M. Buscando superar o sofrimento impulsionada pela esperança: a experiência da criança com câncer. Acta Oncol Bras. 1997; 17(3): 99-108. 
Enskär K, Carlsson M, Golsäter M, Hamrin E, Kreuger A. Life situation and problems as reported by children with cancer and their parents. J Pediatr Oncol Nurs. 1997a; 14(1): 18-26.

Enskär K, Carlsson M, Golsäter M, Hamrin E, Kreuger A. Parental reports of changes and challenges that result from parenting a child with cancer. J Pediatr Oncol Nurs. 1997b; 14(3):156-63.

Enskär K, Carlsson M, Hamrin E, Kreuger A. Swedish health care personnel's perceptions of disease and treatment-related problems experienced by children with cancer and their families. J Pediatr Oncol Nurs. 1996; 13(2):61-70.

Enskär K, von Essen L. Important aspects of care and assistence for children with cancer. J Pediatr Oncol Nurs. 2000; 17(4):239-49.

Eiser C, Eiser JR, Stride CB. Quality of life in chidren newly diagnosed with cancer and their mothers. Health and Quality of Life Outcomes [periódico na Internet] 2005 [citado 2005 Abr 19]. Disponível em http://hqlo.com/content/3/1/29.

Franck LS, Callery P. Re-thinking family-centred care across the continuum of children's healthcare. Child Care Health Dev. 2004; 30(3):265-77.

Frank NC, Brown RT, Blount BL, Bunke V. Predictors of affective responses of mothers and fathers of children with cancer. Psychooncology. 2001; 10(4):293-304.

Françoso LPC, Valle ERM. Histórias contadas por crianças com câncer. Acta Oncol Bras 1994; 14(4):167-74.

Goldbeck L. Parental coping with the diagnosis of childhood cancer: gender effects, dissimilarity within couples, and quality of life. Psychooncology. 2001; 10:325-35.

Grootenhuis MA, Last BF. Predictors of parental emotional adjustment to childhood cancer. Psychooncology. 1997; 6:115-28. 
Han HR. Korean mothers' psychosocial adjustment to their children's cancer. J Adv Nurs. 2003; 44(5):499-506.

Hedström M, Haglund K, Skolin I, von Essen L. Distressing events for children and adolescents with cancer: child, parent, and nurse perceptions. J Pediatr Oncol Nurs. 2003; 20(3):120-32.

Hillman KA. Comparing child-rearing practices in parents of children with cancer and parents of healthy children. J Pediatr Oncol Nurs. 1997; 14(2):5367.

Hoekstra-Weebers JEHM, Jaspers JPC, Kamps WA, Klip EC. Psychological adaptation and social support of parents of pediatric cancer patients: a prospective longitudinal study. J Pediatr Psychol. 2001; 26(4):225-35.

Holm KE, Patterson JM, Gurney JG. Parental involvement and familycentered-care in the diagnostic and treatment phases of childhood cancer: results from a qualitative study. J Pediatr Oncol Nurs. 2003; 20(6): 301-13.

Hung JW, Wu YH, Yeh CH. Comparing stress levels of parents of children with cancer and parents of children with physical disabilities.

Psychooncology. 2004; 13:898-903.

James K, Keegan-Wells D, Hinds PS, Kelly KP, Bond D, Hall B, Mahan R, Moore IM, Roll L, Speckhart B. The care of my child with cancer: parents' perceptions of caregiving demands. J Pediatr Oncol Nurs. 2002; 19(6):21828.

Jeon YH, Madjar I. Caring for a family member with chronic mental illness. Qual Health Res. 1998; 8(5):694-706.

Judson LH. Protective care: mothering a child dependent on parenteral nutrition. J Fam Nurs. 2004; 10(1):93-120.

Kimura AF. A construção da personagem mãe: considerações teóricas sobre identidade e papel materno. Rev Esc Enf USP. 1997; 31(2):339-43. 
Leavitt M, Martinson IM, Liu CY, Armstrong V, Hornberger L, Zhang J, Han X. Common themes and ethnic differences in family caregiving the first year after diagnosis of childhood cancer: part II. J Pediatr Nurs. 1999; 14(2):110-22.

Levi RB, Marsick R, Drotar D, Kodish ED. Diagnosis, disclosure, and informed consent: learning from parents of children with cancer. J Pediatr Hematol and Oncol. 2000; 22:3-12.

Liddle J, Carlson G, McKenna K. Using a matrix in life transition research. Qual Health Res. 2004; 14(10): 1396-417.

Martins VB. Angelo M. A organização familiar para o cuidado dos filhos: percepção das mães em uma comunidade de baixa renda. Rev Latino-Am. Enfermagem. 1999; 7(4):89-95.

Martinson IM, Liu-Chiang CY, Yi-Hua L. Distress symptoms and support systems of chinese parents of children with cancer. Cancer Nurs. 1997; 20(2):94-9.

McGrath P. Findings on the impact of treatment for childhood acute lymphoblastic leukaemia on family relationships. Child Fam Soc Work. 2001; 6:229-37.

Meleis Al, Sawyer LM, In EO, Messias, DAKH, Schumacher K. Experiencing transitions: an emerging middle-range theory. Adv Nurs Sci. 2000; 23(1):12.

Melo LL, Valle ERM. Equipe de enfermagem, criança com câncer e sua família: uma relação possível. Pediatr Mod 1999; 35(12):970-2.

Mercer M, Ritchie J. Tag team parenting of children with cancer. J Pediatr Nurs. 1997; 12(6):331-41.

Moore JB, Mosher RB. Adjustment responses of children and their mothers to cancer: self-care and anxiety. Oncol Nurs Forum. 1997; 24(3):519-25.

Mohr WK. Interpretive interacionism: Denzin's potencial contribuition to intervention and outcomes research. Qual Health Res. 1997; 7(2):270-86. 
Moreira PL, Dupas G. Compreendendo o significado de saúde e de doença na percepção da criança. Rev Latino-Am Enfermagem 2003; 11(6):757-62.

Moreira PL, Dupas G. Vivendo com o diabetes: a experiência contada pela criança. Rev Latino-Am Enfermagem 2006; 14(1):25-32.

Moro MR. Os ingredientes da parentalidade. Trad. Julia Castinho e Regina Orth de Aragão. [citado 2007 Fev 01]. 2004. Disponível em:

http://www.clinique-transculturelle.org

Mu PF, Ma FC, Ku SM, Shu HQ, Hwang B, Kou BIT. Families of Chinese children with malignancy: the factors impact on mother's anxiety. J Pediatr Nurs. 2001; 16(4):287-95.

Nelms TP. A most wonderful, tragic experience: the phenomenon of mothering in caregiving an adult son with AIDS. J Fam Nurs. 2002; 8(3):282300 .

Norberg AL, Lindblad F, Boman KK. Coping strategies in parents of children with cancer. Soc Sci Med. 2005; 60:965-75.

Norberg AL, Lindblad F, Boman KK. Support-seeking, perceived support, and anxiety in mothers and fathers after children's cancer treatment.

Psychooncology. 2006; 15:335-43.

Oliveira I, Angelo M. Vivenciando com o filho uma passagem difícil e reveladora - a experiência da mãe acompanhante. Rev Esc Enf USP. 2000; 34(2):202-8.

Patistea E. Description and adequacy of parental coping behaviours in childhood leukaemia. Intern J Nurs Stud. 2005; 42(3): 283-96.

Patistea E, Babatsikou F. Parents' perceptions of the information provided to them about their child's leukaemia. Eur J Oncol Nurs. 2003; 7(3):172-81. 
Patistea E, Makrodimitri P, Panteli V. Greek parents' reactions, difficulties and resources in childhood leukaemia at the time of diagnosis. Eur $\mathrm{J}$ Cancer Care. 2000; 9:86-96.

Patterson JM, Holm KE, Gurney JG. The impact of childhood cancer on the family: a qualitative analysis of strains, resources, and coping behaviors. Psychooncology. 2004; 13:390-407.

Pyke-Grimm KA, Degner L, Small A, Mueller B. Preferences for participation in treatment decision making and information needs of parents of children with cancer: a pilot study. J Pediatr Oncol Nurs. 1999; 16(1):13-24.

Ray, LD. Parenting and childhood chronicity: making visible the invisible work. J Pediatr Nurs. 2002; 17(6):424-38.

Ribeiro CA, Angelo M. O significado da hospitalização para a criança préescolar: um modelo teórico. Rev Esc Enf USP. 2005; 39(4):391-400.

Sawyer M, Antoniou G, Toogood I, Rice M, Baghurst P. Childhood cancer: a 4-year prospective study of the psychological adjustment of children and parents. J Pediatr Hematol Oncol. 2000; 22(3):214-20.

Scott-Findlay S, Chalmers K. Rural families' perspectives on having a child with cancer. J Pediat Oncol Nurs. 2001; 18(5):205-16.

Shapiro J, Perez M, Warden MJ. The importance of family functioning to caregiver adaptation in mothers of child cancer patients: testing a social ecological model. J Pediatr Oncol Nurs. 1998; 15(1):47-54.

Silva MCP, Solis-Ponton L. Ser pai, ser mãe - parentalidade: um desafio para o terceiro milênio. São Paulo: Casa do Psicólogo, 2004.

Sloper P. Needs and responses of parents following the diagnosis of childhood cancer. Child: Care Health Dev. 1996; 22(3):187-202.

Sloper P. Predictors of distress in parents of children with cancer: a prospective study. J Pediatr Psychol. 2000; 25(2):79-91. 
Snider JB, Clements A, Vazsonyi AT. Late adolescent perceptions of parent religiosity and parenting process. Fam Proc. 2004; 43(4):489-502.

Steele RG, Long A, Reddy KA, Luhr M, Phipps S. Changes in maternal distress and child-rearing strategies across treatment for pediatric cancer. $\mathrm{J}$ Pediatr Psychol. 2003; 28(7):447-52.

Steele RG, Dreyer ML, Phipps S. Patterns of maternal distress among children with cancer and their association with child emotional and somatic distress. J Pediatr Psychol. 2004; 29(7):507-17.

Svavarsdottir EK. Caring for a child with cancer: a longitudinal perspective. J Adv Nurs. 2005a; 50(2):153-61.

Svavarsdottir EK. Gender and emotions: icelandic parents experiencing childhood cancer. Intern J Nurs Stud. 2005b; 42:531-8.

Tarr J, Pickler RH. Becoming a cancer patient: a study of families of children with acute lymphocytic leukemia. J Pediatr Oncol Nurs. 1999; 16(1):44-50.

Trask PC, Paterson AG, Trask CL, Bares CB, Birt JA, Maan C. Parent and adolescent adjustment to pediatric cancer: Associations with coping, social support, and family function. J Pediatr Oncol Nurs. 2003; 20(1):36-47.

Ulla EK. Emotional reactions in parents and children after diagnosis and treatment of a malignant tumour in the eye. Child Care Health Dev. 2000; 26(5):415-28.

von Essen L, Enskär K, Skolin I. Important aspects of care and assistance for parents of children, 0-18 years of age, on or off treatment for cancer. Parent and nurse perceptions. Eur J Oncol Nurs. 2001; 5(4):254-64.

Wagner A, Predebon J, Mosmann C, Verza F. Compartilhar tarefas? Papéis e funções de pai e mãe na família contemporânea. Psicol teor pesqui. 2005; 21(2):181-186. 
Ward-Smith P, Kirk S, Hetherington M, Hubble CL. Having a child diagnosed with cancer: an assessment of values from the mother's viewpoint. J Pediatr Oncol Nurs. 2005; 22(6):320-7.

Weber LND, Prado PM, Viezzr AP, Brandenburg OJ. Identificação de estilos parentais: o ponto de vista dos pais e dos filhos. Psicol reflex crít. 2004; 17(3):323-31.

Wells DK, James K, Stewart JL, Moore IM, Kelly KP, Moore B, Bond D, Diamond J, Hall B, Mahan R, Roll L, Speckhart B. The care of my child with cancer: a new instrument to measure caregiving demand in parents of children with cancer. J Pediatr Nurs. 2002; 17(3):201-10.

Wright LM. Espiritualidade, sofrimento e doença: idéias para curar. Coimbra: Ariadne Editora, 2005.

Wright LM, Leahey M. Enfermeiras e famílias: um guia para avaliação e intervenção na família. 3 ed. São Paulo: Roca, 2002.

Wills BSH. The experiences of Hong Kong chinese parents of children with acute lymphocytic leukemia. J Pediatr Nurs. 1999; 14(4):231-8.

Wong MY, Chan SW. The coping experience of chinese parents of children diagnosed with cancer. J Clinical Nurs. 2005; 14:648-9.

Woodgate RL. Life is never de same: childhood cancer narratives. Eur $\mathrm{J}$ Cancer Care. 2006; 15: 8-18.

Woodgate RL, Degner LF. Cancer symptom transition periods of children and families. J Adv Nurs. 2004; 46(4): 358-68.

Woodgate RL, Degner LF. "Nothing is carved in stonel": uncertainty in children with cancer and their families. Eur J Oncol Nurs. 2002; 6(4):191-202.

Yeh $\mathrm{CH}$. Gender differences of parental distress in children with cancer. J Adv Nurs. 2002; 38(6):598-606. 
Yeh $\mathrm{CH}$. Dynamic coping behaviors and process of parental response to child's cancer. Appl Nurs Res. 2003; 16(4):245-55.

Yiu JMC, Twinn S. Determining the needs of chinese parents during the hospitalization of their child diagnosed with cancer: an exploratory study. Cancer Nurs. 2001; 24(6):483-9.

Young B, Dixon-Woods M, Heney, D. Identity and role in parenting a child with cancer. Pediatr Rehabil. 2002a; 5(4):209-14.

Young B, Dixon-Woods M, Findlay M, Heney D. Parenting in a crisis: conceptualising mothers of children with cancer. Soc Sci Med. 2002b; 55(10):1835-47.

Young B, Dixon-Woods M, Windridge KC, Heney D. Managing communication with young people who have a potentially life threatening chronic illness: qualitative study of patients and parents. Brit Med J. 2003; 326:305-8. 